Andrews University

Digital Commons @ Andrews University

Professional Dissertations DMin

Graduate Research

1996

\title{
A Christian Response to Zambian Death Rituals
}

Cornelius Mulenga Matandiko

Andrews University

Follow this and additional works at: https://digitalcommons.andrews.edu/dmin

Part of the Practical Theology Commons

\section{Recommended Citation}

Matandiko, Cornelius Mulenga, "A Christian Response to Zambian Death Rituals" (1996). Professional Dissertations DMin. 689.

https://dx.doi.org/10.32597/dmin/689

https://digitalcommons.andrews.edu/dmin/689

This Project Report is brought to you for free and open access by the Graduate Research at Digital Commons @ Andrews University. It has been accepted for inclusion in Professional Dissertations DMin by an authorized administrator of Digital Commons @ Andrews University. For more information, please contact repository@andrews.edu. 
ABSTRACT

A CHRISTIAN RESPONSE TO ZAMBIAN DEATH RITUALS

\section{by}

Cornelius Mulenga Matandiko

Adviser: Jon Lee Dybdahl 


\section{ABSTRACT OF GRADUATE STUDENT RESEARCH \\ Dissertation}

Andrews University

Seventh-day Adventist Theological Seminary

Title: A CHRISTIAN RESPONSE TO ZAMBIAN DEATH RITUALS

Name of researcher: Cornelius Mulenga Matandiko

Name and degree of faculty adviser: Jon Lee Dybdahl, Ph.D. Date completed: May 1996

Problem

Adventist Christians in Zambia wrestle with the tension between elements of their traditional religion and Western Christianity. Many of them, fearing spirits of the dead, participate in traditional funeral practices aimed at protecting them from spirit attacks. This presents a problem because many of these practices are contrary to what the Bible proclaims. 
Method

In this study, a traditional understanding of death and death rituals is developed. This is followed by a biblical understanding of death and death rituals. An analysis and evaluation of cultural views in the light of the Bible teachings on death, death rituals, and spirits is pursued. A model contextualization process is developed that local churches can use to analyze their own cultural ways in the light of the Scripture. A questionnaire and interviews were conducted to ascertain the areas that needed urgent study. Finally, a seminar program is developed that focuses on teaching eight lessons on death, death rituals, and other related topics.

\section{Results}

The traditional understanding shows that all tribes in Zambia believe in spirit influerce. It reveals early people movements, wars, and trade as factors that contributed to the mixing of cultures and similar beliefs. The most common element found in all tribes is the fear of spirits of the dead. The biblical study section concludes that the dead know nothing and therefore have no influence upon the living. An examination of the words "soul" and 
"spirit" reveals that these words do not carry with them any idea of continued existence outside the physical body after one dies. In comparing what is practiced in culture and what the Bible teaches, it was discovered that there are some cultural practices that are in agreement with Bible principles, and there are some that are in conflict with some Bible teaching. The results of the questionnaire and interview identified eight areas of need relating to the subject of death. Lessons were prepared to speak to these areas of need and educate both pastors and laity in cultural issues affecting the Church in Zambia.

\section{Conclusion}

Since the gospel commission was given to the Church and the presence of the Holy spirit assured, believers of every culture must be trained to be responsible and must be equipped with the ability to decide what in their culture is to be discarded and what is to be kept. This training program will enable Zambian Adventists to perform the tasks of contextualization in relation to death and death rituals effectively. 


\author{
Andrews University \\ Seventh-day Adventist Theological Seminary
}

A CHRISTIAN RESPONSE TO ZAMBIAN DEATH RITUALS

\begin{abstract}
A Dissertation
Presented in Partial Fulfillment

of the Requirements for the Degree

Doctor of Ministry
\end{abstract}

by

Cornelius Mulenga Matandiko

May 1996 

A CHRISTIAN RESPONSE TO ZAMBIAN DEATH RITUALS

A project dissertation presented in partial fulfillment of the requirements for the degree Doctor of Ministry

by

Cornelius Mulenga Matandiko

APPROVAL BY THE COMMITTEE:
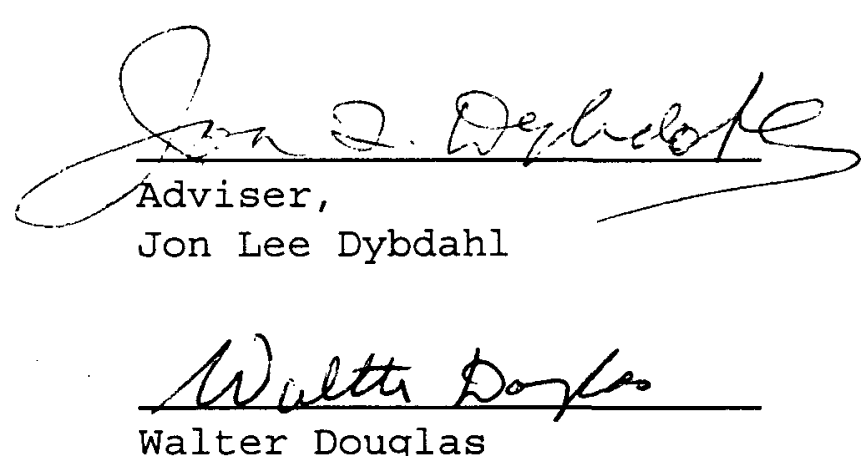

Walter Douglas

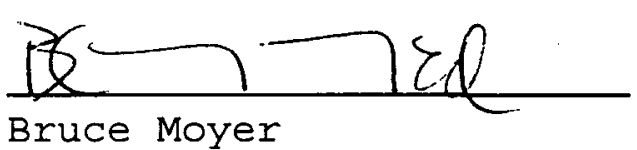

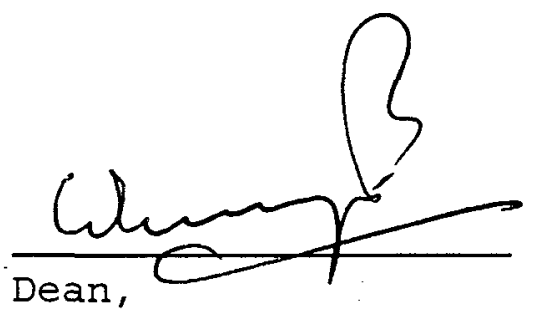

SDA Theological Seminary

$$
\frac{\pi \operatorname{lig} 29,1996}{\text { Date approved }}
$$


ACKNOWLEDGMENTS .................... vii

\section{Chapter}

I. INTRODUCTION.................... 1

Statement of the Problem............ 1

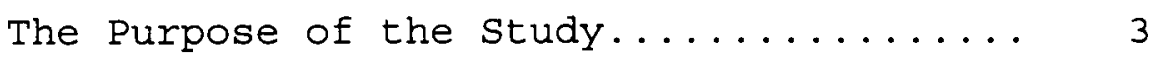

Significance.................. 4

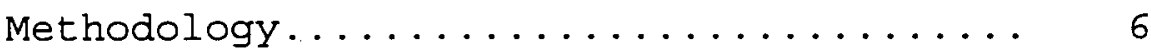

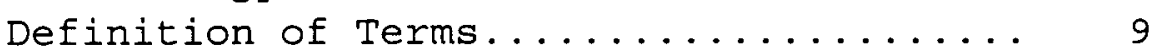

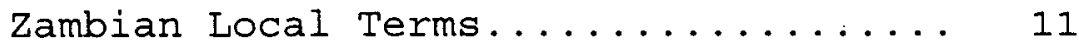

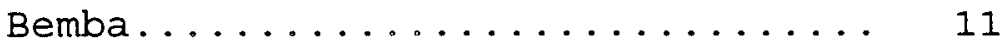

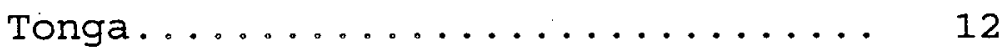

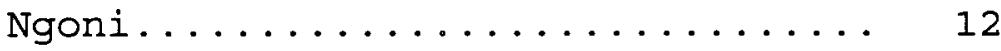

Lozi........................ 13

II. TRADITIONAL UNDERSTANDING OF DEATH

AND DEATH RITUALS.................. 14

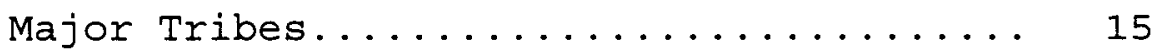

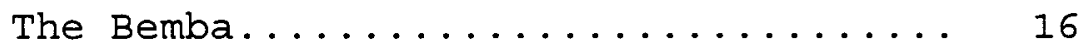

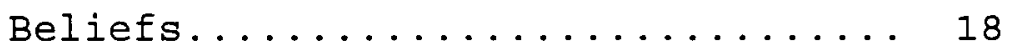

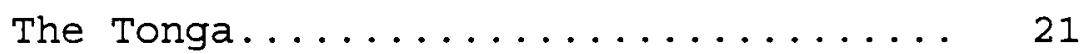

Beliefs................... 24

The Ngoni................. 27

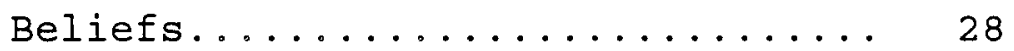

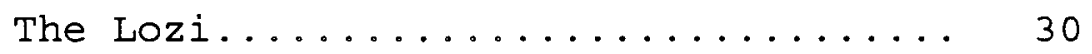

Beliefs................ 32

Description of Funeral Rituals......... 34

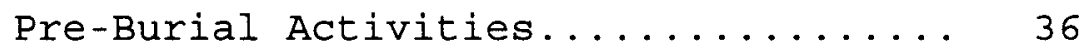

Bemba................ 36

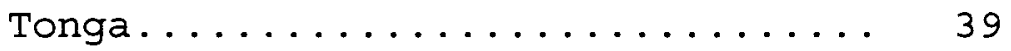

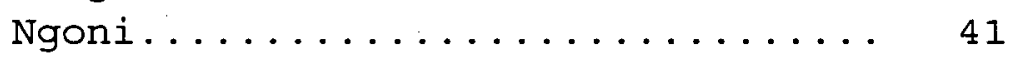

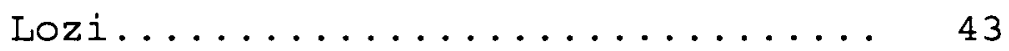

Burial Activities.............. 44 
Bemba................... 44

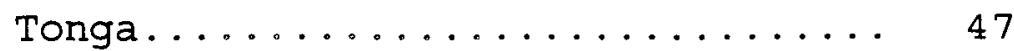

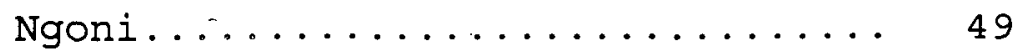

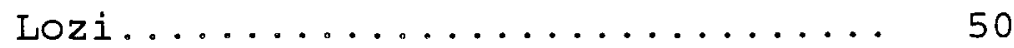

Post-Burial Activities............ 52

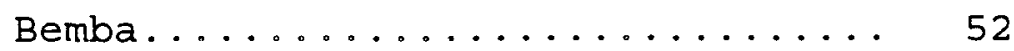

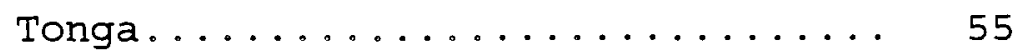

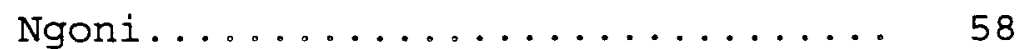

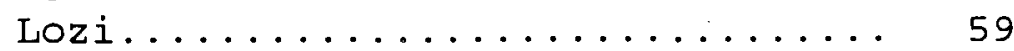

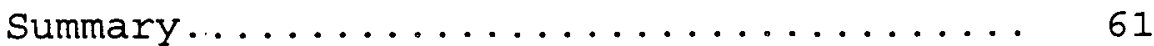

Issues Raised................ 64

\section{THE BIBLICAL UNDERSTANDING OF DEATH}

AND DEATH RITUALS...............

Death Rituals in the old Testament...... 67

Pre-Burial Activities............ 68

Burial Activities.............. 70

Post-Burial Activities........... 74

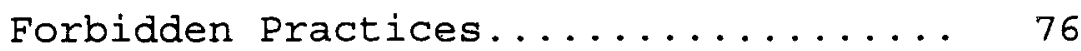

Beyond the Mourning Period......... 78

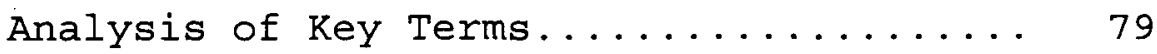

Death as sleep................ 80

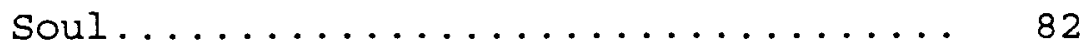

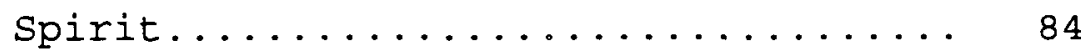

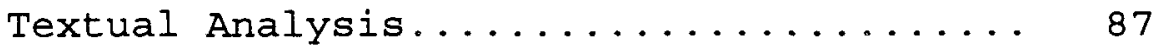

Possible Interpretations........... 88

First Interpretation........... 88

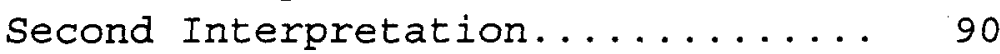

Third Interpretation............ 91

Fourth Interpretation........... 92

Death Rituals in the New Testament...... 94

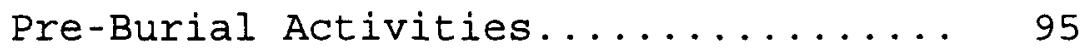

Burial Activities............... 96

Post-Burial Activities........... 97

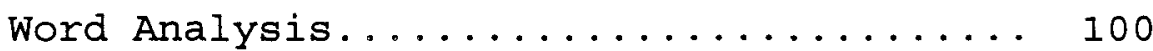

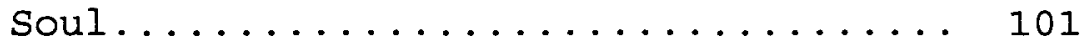

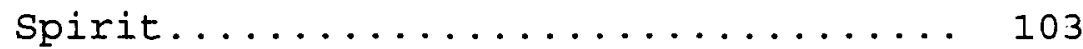

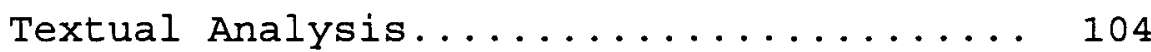

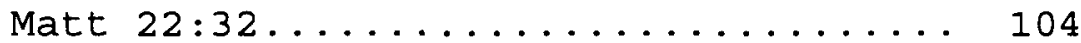

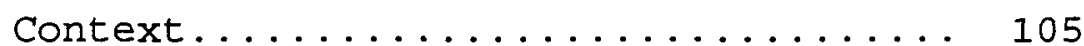

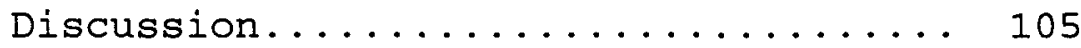

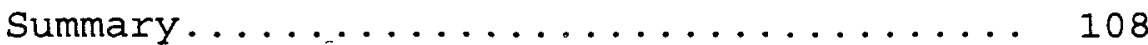


IV. ANALYSIS OF TRADITIONAL VIEWS IN THE LIGHT

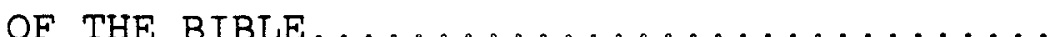

Pre-Burial Activities............... 113

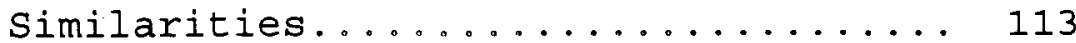

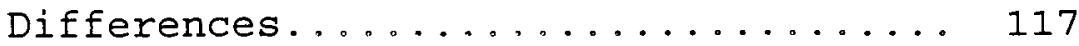

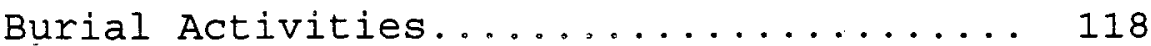

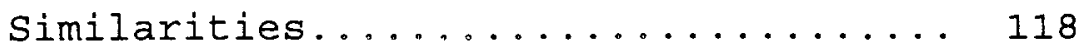

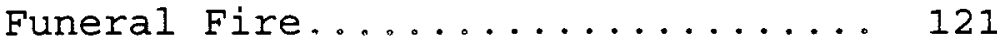

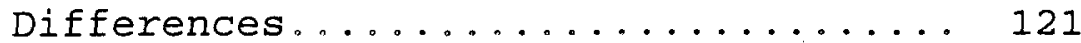

Post-Burial Activities............... 124

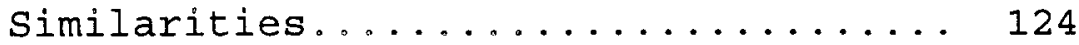

Differences.................... 127

Strictly Forbidden Practices........... 130

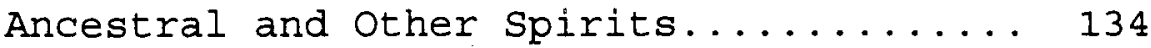

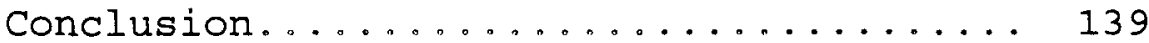

V. A CONTEXTUAL, CHRISTIAN RESPONSE TO FUNERAL PRACTICES.................. 140

Target Audience................... 141

Selection of Topics............... 142

Teaching Method................. 144

Preliminary Organization............ 146

Model Contextualization Process........ 146

Cultural syncretism............ 147

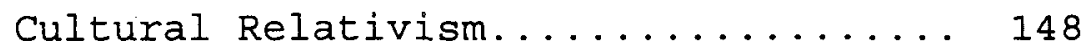

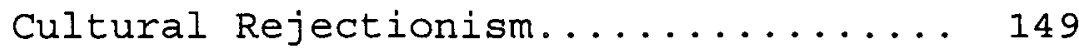

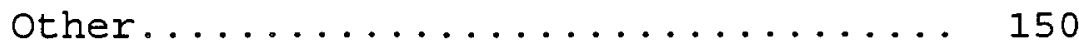

Critical Contextualization......... 150

1. Awareness................ 150

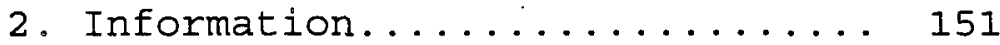

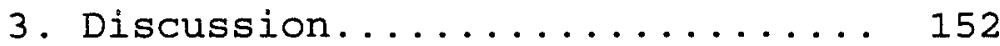

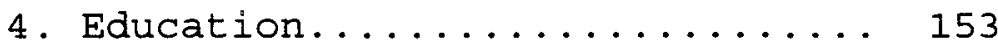

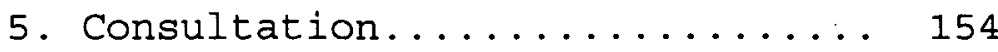

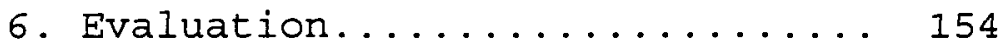

7. Decision................. 155

8. Implementation............. 156

VI. SUMMARY, CONCLUSION AND RECOMMENDATIONS.... 157

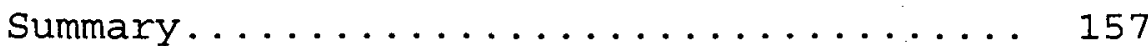

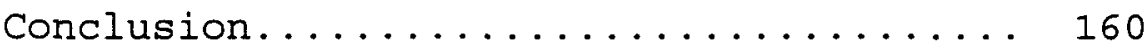




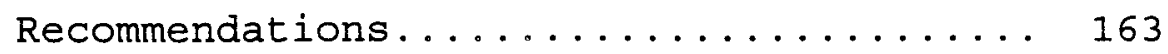

Appendix

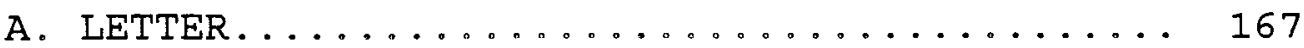

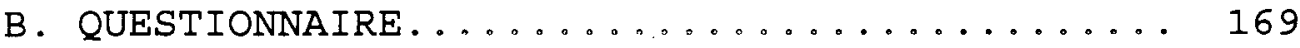

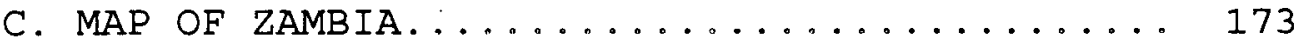

D. NEWSPAPER CLIPPING

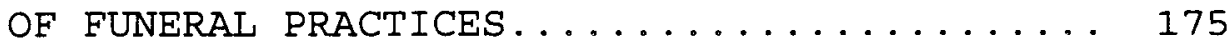

E. SEMINAR LESSONS................. 177

BIBLIOGRAPHY ....................... 219

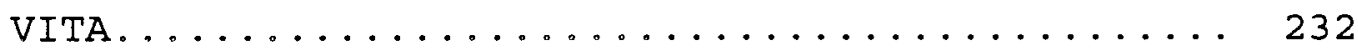




\section{ACKNOWLEDGEMENTS}

Finally the work is done. I would like to say a few

"thank-yous:"

Principally to God, who has sustained my life and health, and that of my family during our stay at Andrews. He supplied everything I ever needed to the end of this dissertation.

Gratitude to my devoted wife for support and encouragement along the way. Thank you to my little children, Charity and Tina, for bearing with my "I'm busy right now, I can't play with you," and for understanding and providing me with cheer and laughter the whole time.

Special thanks are due to Dr. Jon Lee Dybdahl who made my work seem easy. Indeed, without his scholarly excellence and Christian touch this dissertation would have been an impossibility. His prompt response to my drafts, clarity of thought, and patience filled my heart with courage to go on. May his tribe increase. 
Special thanks also to Dr. Walter Douglas, a hardworking minister. Everytime I talked to him he was calm, smart, and funny, and always inspired me to believe in my ability to do the task. From the start he was willing to stick with this first-time researcher, impressively living up to his promises to be available whenever I needed him. I would like to thank all my Zambian friends who were willing to share their information and ideas, and those who enabled questionnaires to reach into the hands of the people and bring them back to me on time.

Finally, thanks to all my seminary professors, for imparting knowledge and skill to me throughout my going in and going out of Seminary Hall. Thanks to the Mission Department for financial support. To all that contributed to the finished dissertation, may our Lord keep us safe in the faith until we meet in the New Jerusalem. 
CHAPTER 1

INTRODUCTION

\section{Statement of the Problem}

Death is an unavoidable event in every society. In Zambia, the event of death comes with a lot of rituals. These rituals are in focus at every funeral in the Zambian traditional society. Behind these rituals is a belief that death is a temporal cessation of activity among people in the community. After a while, people believe, the dead are changed into spirits. If the deceased was a good leader in real life, one is called upon to participate in the social functions of the society. If not, the person can still come back as a ghost to torment one's enemies. Members of the clan can be troubled by this spirit if they fail to perform rituals for the dead or are careless in matters of traditional taboos. Strange illnesses, mental derangement, and death have been associated with spirit involvement. To prevent such spirit-borne calamities, various practices have been used. 
When Christianity was first introduced in Zambia, the early local Christians were led by missionaries to discard many of their funeral rituals without understanding why. In their search for identity and authenticity, some Zambians in the contemporary period are reaffirming the values of traditional funeral practices and going back to their roots. Others are still judging everything traditional and cultural as pagan and to be done away with. The Seventh-day Adventist church does not allow Christians to participate in most of the traditional funeral practices, while society expects every mourner to participate. As a result, many Zambian Adventist Christians suffer at the hands of their non-Christian and non-Adventist families.

In addition to this, Adventist Christians wrestle with the tension between elements of their traditional religion and Western Christianity. Many Christians still do not understand the true Christian stand on funeral practices. A lot more, fearing spirits of the dead folks, do not know what to do when faced with the situation. Reaction to this has come in three ways. First, some have rejected every traditional funeral 
practice as pagan, and have taken on everything brought by missionaries as Christian. Second, others have continued to practice everything traditional as just a cultural way of life, and have judged everything brought by missionaries as just part of their culture being imposed on them. Third, many more, realizing that some practices are obviously evil and non-biblical, yet afraid of being under spirit attack, have secretly practiced the rituals without the church officials' knowledge. This has led to having a lot of nonbiblical practices going underground.

\section{The Purpose of the study}

This is an anthropological, biblical, and missiological study of traditional funeral practices in Zambia. These funeral rituals have been a major hinderance to many believers in internalizing the biblical principles in their lives. The task of this research is to develop a program that will equip pastors and laity in the Zambia Union Mission to understand pagan funeral rituals and replace them with acceptable Bible-based Christian practices.

Various questions need addressing and answering to 
accomplish this task. As an anthropological study, what are the issues involved in funeral practices? What are the beliefs about death behind the practices? As a biblical study, what does the Bible say about death and death rituals? What issues from the cultural practices can be addressed by the Bible and what principles are there to address cultural issues? Finally, as a missiological study, this research finds out what process Christians need to use to analyze their ways in the light of the Bible. It needs to find a way of propagating the gospel in cultural terms without compromising Christian standards. Are there Christian alternatives to funeral practices in Zambia?

\section{Significance}

This project relates to the total population of Zambia, which is currently $8,023,000$ people. ${ }^{1}$ of this population, the latest report of December 31, 1995, shows, there are 252,992 baptized Seventh-day Adventists, and 758,992 total adherents. ${ }^{2}$ There are 1,120 churches and

${ }^{1}$ The Europa Yearbook, vol. 2 (London: Europa Pub., 1995), 3386 .

${ }^{2}$ B. Ndatoya, Church Ministries Director, Zambia Union of SDA Church, telephone interview by author, January 31 , 
companies and a total of 168 pastors to care for all the churches and companies. ${ }^{1}$

All Christians in Zambia at one time or another are faced with traditional practices performed at funerals. Some of these practices involve activities that contradict Bible teachings. One important activity, for instance, that needs addressing involves sexual relations with a clan relative of the deceased to prevent the spirit of the dead person from bringing suffering upon the living. This sexual intercourse with a clan relative of the deceased is the cleansing process used to drive away the death-causing spirit from the bereaved. Many Christians, fearing these spirits, also go through this cleansing process. Such a practice compromises God's law of not committing adultery or fornication.

The Seventh-day Adventist Church has taught people about the state of the dead and spiritualism. Regardless of these teachings, the fear of spirits still prevails. Whenever there is a death in the family, many Christians 1996.

\section{${ }^{1}$ Ibid.}


6

consult spirit mediums in connection with death and death rituals.

Some Christians who consult spirit mediums feel Christianity has failed to provide answers in matters of spirits and traditional rituals. These have viewed Christianity as a foreign religion. Therefore, people with strong leanings towards local cultural forms and expressions have been alienated from Christianity and Adventism in particular.

\section{Methodology}

This dissertation being an interdisciplinary study employs three major disciplines: anthropology, theology, and missiology. As an anthropological study, this dissertation is based on the author's personal observation as a Zambian, having been brought up within the context.

It is also based on a survey conducted for the purpose of collecting data pertinent to this study. Questionnaires were sent to fifty local people: twenty-five pastors and twenty-five laity. The author also interviewed eight students from Zambia who are currently studying at Andrews University or some nearby colleges in Michigan. To 
provide an outsider's view of the Zambian culture, five former missionaries to Zambia were interviewed.

Library research provided information from secondary resources for all the three disciplines involved in the study. Resources used were the available books, journals, magazines, and other published literature relating to theological, missiological, and anthropological issues. The three resources came mainly from the James white Library at Andrews University and the use of inter-library loan services.

The selected literature used included published and unpublished projects and dissertations already written on socio-cultural issues in Africa; literature on death and funeral practices in Zambia. It has also taken into consideration published literature on spirits and ancestral veneration. What the Bible says on death and rituals is taken as conclusive since the study analyzes traditional practices in the light of scriptural revelations.

This study is divided into six chapters. The first chapter introduces the whole dissertation, with its purpose, significance, and methodology.

Chapter 2 gives a brief introduction to the tribes 
involved in the study and their beliefs that come into play in the funeral practices. It then describes the funeral practices as they are done in the local cultural way. Chapter 3 provides a study of relevant passages in both the old and New Testaments on death and death rituals. Some Hebrew and Greek words translated "soul" and "spirit" are analyzed to find out if they carry an idea of a neverdying entity that comes back as either an ancestor or menacing spirit.

Chapter 4 is an analysis and evaluation of cultural views in the light of the Bible teachings on death, death rituals, and spirits.

Chapter 5 provides a model contextualization process that local churches can use to analyze any of their own cultural ways in the light of the scripture and to formulate principles to go by when faced with cultural issues that are questionable to Christian values. Lessons for educating both pastors and laity in these issues are developed.

Chapter 6 has a summary, conclusions, and some recommendations.

This research is concerned primarily with the moral aspects of the problem of rituals. It does not provide a 
detailed step-by-step analysis of each tribe's belief and practices--only an overview of the main issues is presented.

The biblical part is not a systematic presentation of death and death rituals, but a collection and arrangement of texts that give light on how God looks at death and death rituals as revealed in the Bible. Two words in Hebrew and Greek, that are translated soul and spirit, have been selected for their proper meanings. These words have not been studied in depth etymologically. This kind of study has been left to the language experts to pursue. Instead, the two words are used and studied only enough to establish a point concerning the survival of the spirit after death or lack thereof.

Textual analysis is limited to the selected two texts that the author deems necessary to the issues under discussion. This research is not an exhaustive study on the subject and is not intended to be an original study; it builds on what others have done, to provide a workable Christian response to death and death rituals in Zambia.

\section{Definition of Terms}

Ancestral Veneration: This is a preferred term to 
ancestral worship. Veneration is used in this paper to mean respect in remembrance of the dead--respect like we give to our living elders.

\section{Contextualization: A process of reconstructing the} symbols of faith to adequately reflect the meaning of the gospel in the thought of the local Zambians.

Traditional: Used in this paper to refer to indigenous cultural practices that have been used and are still being practiced in the Zambian local society. The word "traditional" is used in the sense of cultural, not as a way of looking at an issue.

Functional substitute: A Christian alternative to pagan practices that is accepted by both Christians and nonChristians.

Traditionalists: Refers to people who prefer cultural practices and fight for their preservation.

Cleansing: Used in this paper for a ritual of removing a spirit from the body. There are various ways used by different tribes to remove an evil spirit from society and individuals. 


\section{Zambian Local Terms}

Bemba

Kabumba: Refers to the creative power of God. This is a name given to God, meaning creator.

Shamfumu: In many cases refers to living kings. In this paper it is used to describe spirits that are given the status of honor belonging to kings.

Ingulu: Used in reference to spirits that are used to bring physical healing.

Imilungu: Generally means gods. It applies to spirits that are believed to control elements in nature.

Ifibanda: Plain evil spirits.

Imangu: Refers both to the drum as an instrument and the rhythm played on it to summon villagers to a funeral.

Umupango: A special term used only for a piece of cloth material tied around the head of female mourners, as a sign of mourning.

Ukulamba: Special type of crawling done at funerals, by the spouse of the deceased.

Ukupyanika: A process of having another person take over the responsibility or affairs left by a deceased. This 
term is sometimes used for levirate marriage, and at other times it is used for a cleansing ritual. Only the context determines the meaning.

Tonga

Chilenga: Usually means originator; refers to God as the prime mover.

Lubumba: Refers to God as the one who molds.

N'ganga: A term that generally means doctor. It is used in this context in reference to different specialists who are influenced by spirits in their practices of divination.

Basangushi: Means ones that have changed. These are elders who after death change into spirits.

Masabe: Spirits that possess human beings. Zelo: Ghosts.

Kuzemba: Used for activities done at funerals, including dancing, running, or walking over the grave.

$\underline{\text { Ngoni }}$

Vimbuza: A popular dance associated with spirits. The dancers are seen in association with dancing spirits that help them perform better. 
Muyeni: A ceremony for dancing and showing acts of bravery or works of charity done by the deceased.

Kugela: A ritual of cutting the hairs of all close relatives of the deceased.

$\underline{\text { Lozi }}$

Muba: Spirits that lay in wait for lone wanderers in the bush. 
CHAPTER 2

TRADITIONAL UNDERSTANDING OF DEATH

AND DEATH RITUALS

This chapter is divided into two major parts. Part one, entitled major tribes, briefly introduces the four tribes strategically located in the four areas of the country: north, east, south, and west. It contains some historical facts about the origins and the beliefs of these tribes. This part also brings into view the dispersions, intrusions, and intermingling of the tribes. These circumstances have a bearing on the people's beliefs about death. Regardless of various nuances in beliefs about death, there are some common patterns of behavior. ${ }^{1}$ It is generally believed that a person who dies passes into a spiritual state of being, and therefore can still have

${ }^{1}$ Lassew Dennis Raelly, "The Development of a Theologically Undergirded Strategy for Mission Employing Small Group structure in the S.D.A. Church in Zambia" (D.Min. project dissertation, Andrews University, 1981), 47. 
influence upon the living. In their efforts to placate the spirits, various rituals have been used. Part two of this chapter, the description of rituals, describes some of the many and varying practices done at the time of death, at burial, and finally after burial.

\section{Major Tribes}

There are seventy-three tribes in Zambia, each with its own customs and patterns of conduct. ${ }^{1}$ It is an involved task to analyze what each tribe believes. This research is limited to the recognized four major tribes, the Bemba in the north, Tonga in the south, Ngoni in the east, and Lozi in the west. Any other tribal group may be mentioned when there is a practice of significance that is radically different from the four in focus. These are selected because," in the absence of a common African language Bemba, Nyanja, Tonga and Lozi have become the four main languages of different parts of the country."2

\footnotetext{
${ }^{1}$ Henry Marrais, "A King Reborn: The story of the Conversion of the Litunga, King of Barotseland," TransAfrica Division Outlook, August 1980, 3 .

${ }^{2}$ Gerdien Verstraelen-Guilhuis, From Dutch Mission Church to Reformed Church in Zambia (Franeker, Netherlands: T. Wever, 1982), 31 .
} 
The Bemba

The Bemba people originally came from the great Luba-Lunda kingdom of southern Zaire and Angola. The tribe's own history reveals that Bembas were founded by a band of adventurers arriving from the Luba-Lunda country. Some historians say Bembas arrived in northeastern Zambia late in the seventeenth century, absorbing some of the people they encountered and driving out others. ${ }^{1}$ Oral tradition and written history have many versions of the origins of the Bembas. Brelsford recounts that

Chiti (who later became Chitimukulu) was the son of a legendary founder of the Lunda who fell from the sky to marry Mukulu a mortal chief. In this version Mwata Yamvwa and Kazembe are cousins of royal but mortal blood. The only fact generally accepted is that the Bemba are of the same stock as the Lunda, were related to Mwata Yamvwa and that Chiti and his followers broke away and migrated eastwards into Northern Rhodesia. One version says that they were followed by Kazembe, another close relative, in the same direction. Another story is that Chiti and Kazembe broke away together-Kazembe staying on the Luapula river, whilst Chiti went on. ${ }^{2}$

${ }^{1}$ Irving Kaplain, Area Handbook for Zambia

(Washington, DC: The American University, 1974), 34.

${ }^{2}$ W. V. Brelsford, The Tribes of Zambia (Lusaka, Zambia: Government Printers, 1965), 39. 
The legend most recounted is one involving Mumbi Mukasa, a beautiful girl with big ears, who fell from heaven. She later married chief Mukulumpe and produced three sons. Chiti, who later became Chitimukulu, was one of the three sons. Mukulumpe had three other sons from another wife, among whom was Kazembe. They all left their father and traveled across Luapula where Kazembe remained, while at the sign of the magician Luchele N'ganga the others continued to establish the Bembaland further north. ${ }^{1}$

Whatever the truth may be, the fact still remains even today that both Mwata Kazembe and Chitimukulu recognize that they came from one place and are related. There are many more chiefs in the Bembaland. The main feature of Bemba rule is the well-ordered chieftainship. There is a hierarchy of chiefs leading to paramountcy. The sub-chiefs acknowledge the spiritual superiority of the incumbent paramount chief. This paramount chief is replaced at the time of his death. Because of the well-ordered chieftainship, there is no struggle over who is to be the next paramount chief. This has contributed to peace and stability in the region.

${ }^{1}$ Andrew Robert, A History of the Bemba (Madison, WI: University of Wisconsin, 1973), 39-40. 


\section{Beliefs}

The Bemba people have many beliefs. This section addresses the factors that influence their particular beliefs about death and funeral practices.

From time unknown, the Bembas believed in one supreme God called Lesa. It is not easy to understand the Bemba idea of God. Sometimes he is regarded as a nature force. When lightening flashes and thunder roars, they often refer to that as God being angry or talking. He is also known as Kabumba, that is, creator. He controls nature, but he remains remote from human affairs. ${ }^{1}$

Spirits are divided into four classes:

1. Ancestral spirits: These are spirits of dead chiefs and village leaders. They were believed to come in animal forms like snakes or lions. There are cases where big snakes were sighted string-tied with beads. It was forbidden to kill such creatures, and these creatures were venerated and often refered to as Shamfumu, chief. In such cases; white flour and some grain are taken to the place,

${ }^{1}$ Irvin Kaplain, ed., Zambia: A Country Study (Washington, DC: The American University, 1979), 97. 
where the animal was sighted, and offered to the creature. ${ }^{1}$ This respect is given to these owners of the land, because the sacredness of the land is vested in the hands of paramount chiefs and their ancestors, hence the phrase, chalo caba shamfumu ne fikolwe. ${ }^{2}$ This phrase is translated, "the land is for the chiefs and their ancestors". These royal ghosts, who may choose to appear in any form, have powers over the fertility of the land.

2. Ingulu: These are spirits of elders or medicine men who died with a desire to perpetuate their healing or divination through someone living. They enter the body of one who begins to behave, talk like the deceased, and prophesy. Werner adds, "Beside making prophesies and finding medicines, these go into trances, dance and make witchcraft accusations." 3 1994), 13 .

${ }^{1}$ Brian Carvey, Bembaland Church (New York: Brill,

${ }^{2}$ Hugo F. Hinfelaar, Bemba Speaking Women of Zambia in a Century of Religious Change (1892-1992) (New York: Brill, 1994), 152 .

${ }^{3}$ Douglass Werner, "Some Developments in Bemba Religious History," Journal of Religion in Africa 4, no. 1 (1971): 21 . 
3. Imilungu: These are nature spirits often entreated to send rain and fertilize crops. ${ }^{1}$ They reside in mountains, hills and rivers. Since these spirits are not of the local dead people, they had their own foreign names, which were given to people they possess. They are believed to be inhabitants of various countries. ${ }^{2}$ Although they are not spirits of the dead, they can cause death if not placated.

4. Ifibanda: Sometimes they are known as, ifiwa. These are plain evil spirits, arising from bad people like wizards after they die. They are the feared malevolent spirits that cause sickness and death. Most "rituals done are aimed at preventing evil and averting displeasure of harmful or potentially harmful forces, " ${ }^{3}$ which are these spirits.

Roberts points out that the dead lived on, more or less strongly as spirits, and it was believed that in

${ }^{1}$ Gullen Gouldsburry and Hubert Sheane, The Great Plateau of Northern Rhodesia (New York: Negro University, 1969), 82 .

${ }^{2}$ Robert, 76 .

${ }^{3}$ Carvey, 16. 
contrast to a high God, they often took a keen interest in the affairs of the living. If for example a family was stricken by disease or death, this might as well be attributed to the displeasure of some ancestral spirit. In that case, the spirit would have to be appeased, not only by a change in behavior but also by offerings and perhaps the performance of special rituals. ${ }^{1}$

The Tonga

The Tonga-Ilas in the southern province of Zambia are claimed to be the first Bantu people in Zambia. They are believed to have migrated very early from the northeast area around Lake Tanganyika ${ }^{2}$ and became the earliest settlers in the southern part of today's Zambia. ${ }^{3}$ These Tonga-Ilas had neither chieftainship nor any form of organization that could identify them as a kingdom. They did not even have a complex oral tradition. ${ }^{4}$

${ }^{1}$ Robert, 73 .

${ }^{2}$ Andrew Dale and Edwin Smith, The Ila-speaking Peoples of Northern Rhodesia (New York: University Books, 1968), 18.

${ }^{3}$ Breslford, 61 .

${ }^{4}$ Kaplain, $72-73$. 
In this paper, Tonga is used to include several other related dialects of those living in the southern part of the country. Because these dialects were never welded into a common society, the government during the colonial period placed them under a single native society. Looking at their several prominent rain makers, the colonial authority chose one to be the paramount. ' Today, "Chief Monze is recognized with many reservations as senior chief." 2

The prominent "physical characteristic of the IlaTonga was the knocking out of the four upper incisor teeth."3 Before the 1930s, they grew and built a cone-like creation of hair known as isusu. Brelsford describes it this way:

A cone-like creation of hair, was built up from the head supported in the middle as it narrowed down by a finely pared horn and ending in a very fine point nearly four feet above the head. ${ }^{4}$

\footnotetext{
IIbid: 80 .

${ }^{2}$ Brelsford, 62 .

${ }^{3}$ Ibid. , 65

${ }^{4}$ Ibid.
} 
The Tonga people were a peaceful agricultural group, living in small hamlets across the plateau. They grew large fields of maize and groundnuts and kept some cattle. ${ }^{1}$ Even today, Tongas are the major cattle owners in Zambia.

The Tongaland suffered many invasions between 1820 and 1830 from the Makololo and Lozi. For a long time, the Tongas were governed by the Lozis who conquered much of the south, taking many of their cattle and wives. This resulted into a mixture of culture between the Lozi and the Tonga. An archaeologist and historian sees evidence showing that small numbers of innovators--iron smelters, Mambari traders, Lozi raiders, European administrators and miners--have caused major changes to human society into areas of economy, material culture and style, political organization and identity. ${ }^{2}$

The Tongas take mukowa, clan relationship, very seriously, because it provides a sense of belonging even though the clan relatives may not belong to the same family. Any member of the mukowa is treated just like a member of the immediate family.

${ }^{1}$ Ibid. , 62 .

${ }^{2}$ Robin Derricourt, Man on the Kafue: The Archaeology and History of Itezhitezhi Area of Zambia (New York: Barber, 1985), 130 . 
Beliefs

The Tongas believe in a supreme God. Tongas have different names ascribed to God. They believe he is the creator, hence, they call him chilenga. Sometimes he is called lubumba, one who molds. Smith and Dale list other ascriptions that the Tonga people use for the one supreme God. ${ }^{1}$ Like many other African traditionalists, they believe in the existence of God, but have not seen him act in their lives.

The Tongas also believe in divination, witchcraft, and sorcery. Traditional leaders in the Tongaland were known to be powerful, and commanded respect when they, through the use of their spirits, made rain. Although there were several rain makers, Chief Monze became prominent in the eyes of colonial masters. Tongas attach much importance to spirits associated with rain. Although death can be a result of natural causes, strange and sudden deaths are believed to be caused by some witch or wizard; hence, relatives go to a N'ganga, a doctor, to seek explanation.

\footnotetext{
${ }^{1}$ Dale and Smith, 201-202.
} 
This consultation is done even when someone is sick from a strange illness.

Ban'ganga are different grades of specialists. Some are specialists in medicine, possessing ability by spirit aid to know medicinal plants in the jungle. These are known as herbalists. Others are sorcerers, who can manipulate impersonal powers and use magic to bring evil to people. Others are diviners who are able to determine the cause of illness or death. ${ }^{1}$

The Tongas believe in ancestral veneration. There is a close relation between the living and the dead. The dead are respected and are given a chance to perpetuate their existence through the lives of the living. ${ }^{2}$ Ancestral spirits come in various forms:

1. Basangushi: These are the departed people who are now changed and may appear in dreams or speak through living beings. These are the ancestral spirits, sometimes known as mizimu, belonging to the clan mukowa. They are

${ }^{1}$ Max Ward Randal, Profile for Victory: New Proposals for Missions in Zambia (Pasadena, CA: Carrey, 1970), 16.

2Stan Shewmaker, Tonga Christianity (Pasadena, CA: Carrey, 1970), 25 . 
directly connected to the living members of the mukowa.

This is why child-naming has to be connected to ancestors. ${ }^{1}$ Basangushi were once community leaders, and now provide for the public ritual. They are linked with the political life of society. Failure to carry out orders by these can react upon the public rather than the individual. During drought, they are called upon to bring rain on the land. ${ }^{2}$

2. Masabe: These are spirits of the dead that are associated with dances. They represent humanity and are known by tribal names, not personal names. These seek vehicles through whom they can express their desires. Failure to carry out instructions of masabe reacts upon those possessed; for they affect their own vehicle. ${ }^{3}$

3. Zelo: These are ghosts. Ghosts are the forgotten local dead ones. They can cause illness and

${ }^{1}$ Brendan P. Carmody, Conversion and Jesuit Schooling in Zambia (New York: Brill, 1992), 23.

${ }^{2}$ Randal, 14 .

${ }^{3}$ Elizabeth Colson, "Spirit Possession Among the Tonga of Zambia," in Spirit Mediumship and Society in Africa, ed. John Beattie and John Middleton (London: Routledge and Kegan Paul, 1969), 71. 
death. These are lower earth spirits, ${ }^{1}$ which fall into the control of sorcerers. These ghosts are believed to live in the graves and in solitary bushes awaiting unsuspecting wanderers.

The Ngoni

In the eastern part of Zambia is found the Chinyanja-speaking people. Ngoni is here used to refer to the mixed tribes of the eastern province of Zambia: Tumbuka, Chewa, Nsenga, Ngoni, and other related dialects.

On November 20,1835, Zwangendaba, leader of the fleeing Nguni from the south, crossed the Zambezi into today's Zambia.2 They conquered and absorbed smaller tribes on the way. Having travelled all the way up to lakes Nyasa and Victoria, Zwangendaba's son Mpezeni decided to turn eastward to the Bembaland. On meeting the Bembas, there were a number of wars fought between the two tribes, with many taken into slavery on both sides. Whenever the Ngonis won the battle they would take their captives and assimilate

${ }^{1} \mathrm{Wm}$. M. J. Van Binsbergen, Religious Change in Zambia (London: Kegan Paul, 1981), 131.

${ }^{2}$ Richard Hall, Zambia (New York: Frederick A. Praeger, 1967), 28. 
them. The Bembas on the other hand sold many of their captives to slave traders. ${ }^{1}$ This assimilation policy had a profound influence upon the cultural practices of the society.

Finally, the Ngoni settled along the Muchinga escarpment in 1850. They conquered and assimilated the Chewa and Nsenga whom they found in the area. Although these patrilineal Ngonis conquered the Chewas and Nsengas, they have in turn been conquered by the matrilineal practices of the Chewa and Nsenga who migrated from the Luba-Lunda empire of southern Zaire. ${ }^{2}$ Therefore, the ZuluNgoni language is not today widely spoken except in song and praises. Chinyanja is the official language of the area, while in the villages Nsenga is common. ${ }^{3}$

Beliefs

The Ngoni believe in a supreme God. God is known as Chiuta. This is a Tumbuka-Nyanja word that translates to

${ }^{1} \mathrm{~L} . \mathrm{H}$. Gann, The Birth of a Plural society (Westport, CT: Greenwood, 1981), 7 .

${ }^{2}$ Kaplain, Area Handbook for Zambia, 88 .

${ }^{3}$ Brelsford, 108 . 
"the great-one of the bow."1 "Chiuta is used within the Christian religious context to refer to God."2 This God is also known as the creator and master of life and death. ${ }^{3}$ The Ngoni believe in ancestral spirits--Vibanda. These are the "most active spiritual agents. . . intervening for good or evil, though their influence is Iimited to the affairs of their relatives." 4 When the ancestral spirits are offended, they are to be placated with offerings of beer, meal, or cloth. ${ }^{5}$ The sacrifices and feasts performed are symbolic of the living and the dead joining together. ${ }^{6}$ Spirits are respected under the Msoro tree (false fig tree). People believe that the high God

${ }^{1} \mathrm{E}$. H. Wendland, of other Gods and other spirits (Milwaukee: Northwestern, 1977), 11.

${ }^{2}$ Hiroshi Obayashi, ed., Death and Afterlife: Perspectives of World Religions (New York: Greenwood, 1992), 11.

${ }^{3}$ Donald Frazer, Winning a Primitive People (Westport, CT: Negro, 1970), 120 .

${ }^{4}$ Ibid. , 124.

${ }^{5}$ Ibid. , 127.

${ }^{6} \mathrm{~J}$. S. La Fontaine, ed., The Interoretation of Ritual (London: Tavistock, 1972), 199. 
works through the spirits of ancestors to help solve their daily problems. ${ }^{1}$

Vimbuza are spirits of dead dancers that are used in dances and other social functions of the community. Sometimes they are referred to as Mashave or Vigorera. Once they are in possession of an individual, they are treated like people. ${ }^{2}$ They may cause a lot of sickness and death. Treatment of sicknesses caused by these spirits can be done only by N'ganga, a traditional doctor. ${ }^{3}$

The Lozi

One of the greatest Central African chieftainships in the seventeenth and eighteenth centuries was the LubaLunda kingdom. Chief Mwata Yamvwo had an expansion policy that enabled the migration of groups like Kazembe, and who established himself in the Luapula and Chitimukulu in the north. The Lozi, under the name Luyana, migrated into

${ }^{1}$ Wendland, 18 .

${ }^{2}$ Bennetta Jules-Rosette, "Faith Healers and Folk Healers: The Symbolism and Practice of Indigenous Therapy in Urban Africa," Religion 11 (1981): 144 .

${ }^{3}$ Gerrie Ter Haar, Spirit of Africa (London: Hurst, 1992), 113 . 
northwestern Zambia as part of the general migration in the 1600s.' The name Barotse, later to be known as Ba Lozi, was given by their conquerors, the makololo; they once called themselves A-Luyi, men of the river, and their old language Siluyana was superseded by Sikololo, continued to be used as a court language by the royal family and the headmen. ${ }^{2}$

The Lozi legend claims that they were always in the plain and were the result of a union between Nyambe (God) and Mbuyu, a female. ${ }^{3}$ However the material culture and linguistic ties with other groups in Zambia, like Bemba, clearly show that they are of a common origin, being Kola.

$$
\text { After the Luyi had settled in the area, they }
$$

conquered the surrounding tribes and absorbed them. In 1830 a migrating horde of Makololo from the suthuland came into the land. Failing to pronounce the word Luyi, they pronounced it Luizi, and further corrupted it to become the present Lozi.4 In 1864, the Lozi prince Sipopa annihilated

${ }^{1}$ Mutumba Mainga, Bulozi Under the Luyana Kings

(London: Longmans, 1973), 21.

${ }^{2}$ Edward C. Tabler, ed., Trade and Travel in Early Barotseland (Los Angeles: University of California, 1963), 1 .

$$
\begin{aligned}
& { }^{3} \text { Mainga, } 7 . \\
& { }^{4} \text { Brelsford, } 9 .
\end{aligned}
$$


the Kololo, but the Kololo culture and language had left an indelible mark on the Luyi. Recovering from the Kololo domination, the Lozi invaded the south and raided the TongaIla on many occasions, taking away their cattle and ruling over them.

Beliefs

The Lozi believe in the supreme God, Nyambe. Like other tribes of Zambia, the Lozi believed in Nyambe being the source of power, but was remote from human affairs. ${ }^{1}$

The Lozi believe in ancestral spirits--Silumba or Makishi. These are ancestors who are concerned with human affairs. Due respect is accorded them in the form of an offering of beer or food. ${ }^{2}$ It is believed that each deceased leaves behind a spirit, which turns to be an ancestral spirit or can be seized by a diviner and used as a familiar. ${ }^{3}$. Ancestral spirits can protect the interests of

${ }^{1}$ Barrie Reynolds, Magic, Divination and Witchcraft Among the Barotse of Northern Rhodesia (Los Angeles: University of California, 1963), 9-10.

${ }^{2}$ Francois Coillard, on the Threshold of Central Africa (London: Frank Cass, 1971), 224.

${ }^{3}$ Reynolds, 10 . 
their descendants, but can punish them if they feel neglected by not having their name perpetuated by a newly born or their craft not perpetuated by another person. ${ }^{1}$ The Muba spirits are neglected dead that live in the bush and lie in wait for anyone who passes unguarded. ${ }^{2}$

The Lozi believe in witchcraft and magic. One of the local features in Lozi traditional beliefs is the effectiveness of witches and diviners. The witch causes sickness and death while the diviner reveals the cause of the enquirer's sickness and brings healing through the use of herbs and/or magic. In most cases, the cause of sickness and death is directed to the unhappy spirits of the ancestors, who are the long-dead relatives.

This section concludes, after looking at the various beliefs that influence people's death ritual, that all the tribes have similar beliefs and motivating factors. They all believe spirits arise from the dead and affect the lives of the living significantly. The effect of these beliefs,

'Victor Turner, The Forest Symbols: Aspects of Ndembu Ritual (New York: Cornell, 1967), 9 .

${ }^{2}$ Reynolds, 10 . 
are portrayed in the various funeral practices which the next section describes.

\section{Description of Funeral Rituals}

The customs and practices in this chapter are common among the Bemba, Tonga, Ngoni, Lozi, and other related tribes and dialects. It is obvious that some form of contact may have occurred among the tribes. Kapenzi, noticing the marked similarities of customs among different African tribes, gives a reason of intermingling through constant mobility, caused by trade and war, as justification for these similarities. ${ }^{1}$

Central in the belief system of all tribes is considering that whatever happens to an individual is directly related to the activity of spirit beings. ${ }^{2}$ Burial customs, therefore, "have the purpose and goal of maintaining tribal integrity and hold in check the many forces which make their environment precarious." 3 Irion

${ }^{1}$ Geoffrey $\mathrm{Z}$. Kapenzi, "Rites of Passage in Four African Tribes," Missiology 3 (1975): 65.

${ }^{2}$ Jules-Rosette, 144 .

${ }^{3}$ Kapenzi, 70 . 
reiterates the idea that the origins of funeral rituals may be found in fear. The dead were believed to be resentful and quick to take revenge, therefore, the funeral rituals served to appease the dead. ${ }^{1}$ The dead then are thought of having prolonged existence beyond the grave, often rising with greater power, freedom, and strength. ${ }^{2}$ As part of the ritual to appease the dead, words of praise are offered to honor the dead and a meal is eaten in the home of the deceased. ${ }^{3}$ This meal is explained by Yoder as necessary in expressing support to the bereaved. It is also an opportunity to express one's sense of belonging to the same suffering humanity. This enables the bereaved to adjust to the loss. ${ }^{4}$

One study conducted on rituals concluded that "ritual acts in general may play a significant role in grief

${ }^{1}$ Paul E. Irion, "Changing Patterns of Ritual Response to Death," Omega 22, no. 3 (1991): 161.

${ }^{2}$ Adele M. Fiske, "Death: Myth and Ritual," JAAR 37 (1969): 251, 265 .

${ }^{3}$ Lonnie Yoder, "The Funeral Meal: A Significant Funeral Ritual," Journal of Religion and Health 25, no. 2 (1986): 157 .

${ }^{4}$ Ibid. 
adjustment."1 Funeral rituals are concerned not only with the death of an individual, but with a loss in the community. The mortuary practices now to be described help us understand the community's attitude towards the dead.

\section{Pre-Burial Activities}

Bemba

When a sick person is at the point of death, the nearest relatives gather. In the Bemba tradition, the uncle or grandfather comes close to the dying person and asks what the cause of death might be. He asks, Chinshi cakulya?-What has caused your death? If the answer points to witchcraft, close relatives are told about it. If the response goes like, nafwa ku chikonko--"I'm dying of a broken heart"--then the spouse is held responsible for the death. The words of a dying person about a spouse are taken very seriously because they determine the kind of treatment towards the surviving spouse that would follow the funeral. ${ }^{2}$

${ }^{1} \mathrm{C}$. Bolton and D. J. Camp, "Funeral Rituals and the Facilitation of Grief Work," Omega 17, no. 4 (1987): 350.

${ }^{2}$ Peter Kaoma, a Bemba lay leader, interview by author, september 2, 1995. 
As soon as signs of death are fully developed, the uncle closes the eyes and mouth of the deceased, then folds the arms over the chest and straightens the legs. This is followed by wailing, which is picked up by all those around, usually women. The death of any person, male or female, young or old, is announced by the beat of a drum called Imangu. This beat uses a distinct rhythm that is only played when a person in the community dies. During this time and throughout the funeral period, the spouse is not allowed to eat any hot or warm food and is not supposed to take a bath or shower.1

The relatives of the dead person quickly put a head band on the person who has lost a close member of the family. This is called Umupango; usually, it is a black piece of cloth worn as a sign of mourning. Men wear a piece of material around their arm or sew a small piece of black cloth on the side of the shirt. ${ }^{2}$ From that time, the dead person is referred to as Umuyashi, the late.

'John Ganley, "After the Priest Leaves," African Ecclesial Review 27, no. 2 (February 1982): 26.

${ }^{2}$ Ibid. 
News about the death spreads fast, especially to the close members of the family who start travelling for the funeral almost immediately. As people arrive at the funeral house, they go into the house, weeping. Inside, they are told about the deceased's sickness and death, in brief. After that, men go outside to join other men while women remain inside the house. ${ }^{1}$

The eldest uncle to the deceased summons all close relatives and plans for the burial. Depending on the time of death, the making of a coffin and digging of the grave commence shortly thereafter. If death happened in the night, then these activities are done early the following day. Burial is not delayed due to lack of refrigeration facilities in the villages. Before the body is finally placed in the coffin, it is washed, lotion applied, clothed, and then placed into the coffin face up. The body has to be buried the same day the grave is dug. If for some reason

${ }^{1}$ Richard W. Sales, "Neighbors in Zambia," Christian Century 102 (February 1985): 207, 208. 
burial does not take place that day, the grave is covered up and another one dug when people are ready for burial.

Tonga

In the Tonga tradition, the funeral ritual is a farreaching ceremony. When a person senses death approaching due to long illness, he returns to his home village. If he dies in town, his body is transported to his home village for burial. It is believed that ancestors have power only in the territory of which they are owners; this is the reason why people are buried where they came from. The dead can be effective in making rain in the area where they know their descendants, and rituals are performed for them. ${ }^{2}$ As soon as it is clear that the person is dead, there is a loud shrill, agonizing cry, which notifies those nearby that the sick person is dead. Near the body the spouse sits close. The body is then prepared for burial by

${ }^{1}$ Mwewa Mwansa, a Zambian studying at Southwest Michigan College, interview by author, August 13, 1995.

${ }^{2}$ Holy Ladislav, Strategies and Norms in a Changing Matrilineal Society: Descent, Succession and Inheritance Among the Toka of Zambia (London: Cambridge, 1986), 134-139. 
shaving the head, anointing the body with butter, and decorating it with beads. ${ }^{1}$

In some cases, they dress the dead, put him in a sitting position, and bring the knees in with the hands folded over the chest. They take the measurements and some men, at the direction of one elderly man, start digging the grave. The grave is dug within the house ground. Some graves are dug right in front of the house near the door step.

Many cattle are slaughtered and are eaten during the funeral, which can last as long as one week or longer depending on the importance of the deceased. Relatives offer the animals that could be used at the funeral and as they slaughter these animals the giver says, "I have mourned for you." Every mourner is expected to come with chidizho, something to weep with. Some bring an ox, a pot of beer, cornmeal, grain, money, or something else. Many cattle belonging to the deceased are slaughtered and cooked for the mourners. When the relatives are ready for burial, the

${ }^{1}$ Dale and Smith, 104. 
procession heads to the burial place--in this case, within the perimeters of the house, in some cases, by the kraal. ${ }^{1}$

$\underline{\text { Ngoni }}$

The Chinyanja-speaking group of people have similar activities with the Bemba. The Yombe, in the northeast, announce the death of a person by a particular beat of a drum. If the person dies in the evening, burial is done the following day. To overcome rigor mortis, the limbs are moved from time to time in the night. Then the corpse is washed, dressed, and wrapped in a white-lined material usually bought for the funeral. The body is then placed in the coffin. ${ }^{2}$

Early in the morning, some men go to dig the grave. The burial place is always a distance from the village. When men are done digging, an elder who is a close relative to the dead inspects it and declares, Nyumba yamara, the house is completed. ${ }^{3}$ As the body is being taken out of the house for burial, wailing intensifies. As soon as the

IIbid., 110.

2Obayashi, 12-14.

${ }^{3}$ Ibid. 
coffin reaches the door, a gun may be fired, depending on the importance of the deceased in the community.

This section shows that in the pre-burial activities, there are many similarities and there are some activities that are special to each tribe. Wailing and weeping seem to be common in all tribes; just as the wearing of some kind of mourning dress for identity and in being sure that a very close member of the family is present, when the sick is about to die, to close the eyes of the deceased. Distinct to the Tonga is burying the dead within the perimeters of the house, with the belief in the effectiveness of the dead, to make rain if buried near their own area. Tonga tribesmen seem to be the only ones who used to shave the head of the dead and bury them folded in a sitting-like position. Large cattle owners, the Tonga and Lozi, offer a lot of animals to be used at the funeral for both eating and a gift to the dead. The Bemba use a lot of chicken and fish during their funerals because they are not cattle growers. Finally, the Lozi are the only tribe that has the practice of keeping a piece of material between the thighs of the bereaved during the funeral. 
Lozi

The Lozi pre-burial activities are similar to the ones described above. They, however, shave. the heads of all close relatives of the deceased. The mourners who arrive late start yelling as they approach the funeral house and get into the house. The ones in the house join in. After a while, they stop yelling and start greeting one another, and a record of the deceased's sickness to death is told to them. ${ }^{1}$ Meanwhile, a big fire is made outside, where the male mourners sit around and sleep until a day after the burial. ${ }^{2}$. Like the Tonga tradition, many animals are slaughtered to feed the mourners.

The widow(er) is kept inside the house, covered with a blanket until the day of burial. The bereaved sits on a traditional reed mat with a piece of material placed between the thighs and is given a straw of grass to hold until after burial. ${ }^{3}$

${ }^{1}$ Francis Kabambe, interview by author, september 2, 1995.

${ }^{2}$ Walton R. Johnson, Worship and Freedom (New York: Africana, 1977), 113.

${ }^{3}$ Godwin Kaluwe, interview by author, August 28, 1995. 


\section{Burial Activities}

Bemba

Just before burial, the Bembas have a tradition called Ukulamba, when the deceased's spouse crawls towards the house from a distance. The surviving spouse is not allowed to walk but crawl into the funeral house, carrying some money or beads to give out. At a convenient time, the body is taken to the burial place amidst a lot of wailing. Songs of praise and messages are sung. The most popular message song is:

Wekaleya Uye mwebako kampanda auti, umuntu washa, wamusha mukucula. Wekaleya, mucilila mwa chilaisha n'ganga, emwalala weno. Uye mweba auti kuno tuli ababulila.

The song tells the dead person that as you go where others have gone, go and tell them that the friend you left is in much misery. Tell the other one in the grave of chilaisha n'ganga that we are getting fewer in number. Praise songs like, we cilya baume tacaba namano, say that the thing that takes men is not wise, but honors men of valor. If an industrious woman is being buried, they sing a praise song like, katutututu musha we bende waya--oh great pounder, slave of the mortar, you are gone. All the way to 
the burial place, the band of mourners march, wailing and singing.

Upon arrival at the gravesite, an elder inspects the grave, making sure that no strange items are thrown inside. A speech is made by the relative's representative, expressing gratitude to the mourners and helpers. A brief life history is told, then the coffin is lowered into the grave. It is important in the Bemba tradition that the head of the deceased point west where the clan came from; others say it is the direction of the setting sun, since the person's life has set. Close relatives throw in a handful of soil, then clan cousins do the burying. The clan cousins joke and tease the mourners throughout the funeral time, yet they are the most helpful and hard-working during the funeral. They make sure that the traditional way of mourning is adhered to. Carvey rightly points out:

The importance of clan structure lay not only in its influence on marriage and therefore on inheritance but also in its control of rituals of social crisis, such as birth and death, where certain functions at burial for example would be performed only by a member of a ritual 'enemy' clan.'

${ }^{1}$ Carvey, 8 . 
As the grave gets filled up with the soil, four twigs or long pieces of grass are planted in the four corners of the hole to determine the boundary of the hole. After the mound is high enough, the boundary markers are pushed into the mound and covered up; they cannot be disposed of in just any manner.

Where there is suspicion of witchcraft, for such cases are not uncommon, some leaves are placed on the grave and words are spoken such as: "If this is from natural causes, then rest in peace, but if it is from someone else, then you come up and take the individual." Reynolds describes some cases involving suspected witchcraft. ${ }^{I}$ At the end, an axe, a hoe, a spear, or something else is placed on top of the grave for identity of what that person used to do in real life. In case of a woman, a plate or pot is broken on top of the grave.

If a twin dies, the surviving twin must be the first to weep before anyone else. Then at burial, a maize cob, or trunk of a banana, is placed inside the coffin next to the dead twin. This is done to lure the spirit into thinking

${ }^{1}$ Pamela Reynolds, Dance Civet Cat: Child Labor in the Zambezi Valley (London: Zed, 1991), 145-148. 
that it is with the other twin in the grave, otherwise he will come back and get the living twin also.

Tonga

In the Tonga burial custom, men come out with their spears, rushing to and fro as if to spear something. Some close relatives cover themselves with ashes and paint themselves with soil. Many gifts are presented and put in the grave, items such as food, utensils, tobacco, beer, and clothing. The Tonga sacrificing at a funeral call to the deceased and bid him to summon the other dead relatives by name, just as he would invite them to an earthly feast. ${ }^{1}$ As they give, they say some words like, ngoyu tombwe wakufweba --"Here is tobacco for you to smoke." Excavations at in'gombe ilede reveal that people were buried with their wealth of gold and copper bangles. ${ }^{2}$

The head of the deceased usually points to the east, and in certain areas objects are placed with the deceased.

${ }^{1}$ Audrey I. Richards, Hunger and Work in a Savage Tribe (Westport, CT: Greenwood, 1985), 186.

${ }^{2}$ Brian M. Fagan, D. W. Phillipson, and S. G. H. Daniels, Iron Age Cultures in Zambia (London: Chatto \& Windus, 1969), 66 . 
Then close relatives throw into the grave a handful of soil. After that, men begin to bury. The chamber is sealed with stones and covered with a small mound, then surrounded by a circle of stones. Some items are displayed or smashed on top of the grave; the number and type varies with the age, sex, and wealth of the buried.' After the grave is covered up, a ritual known as kuzemba begins. This time people walk or run on top of the grave to and fro, uttering some words of praise to the deceased. After this, a big fire is made over the grave; this fire is kept burning the whole period of mourning, which can be a week. During this period, every day and night songs of praise are sung (e.g., waona waona shumbwa wa ku bweengwa, langa meja abanyama...--"You have slept oh Iion of bweengwa, look at the horns of your animals").2

Tongas burying their dead within the perimeters of the house and other tribes who bury their dead in communal cemeteries not far from their homes tend to portray an idea

${ }^{1}$ Ian Hodder, Symbols in Action: Ethno-archaeological studies of Material Culture (London: Cambridge University, $1982), 163$.

${ }^{2}$ Mrs. Coaster Munyengwe, interview by author, August $12,1995$. 
that the ancestors are connected to the contemporary community. ${ }^{1}$ The propinquity of cemetery and settlement reveal a common and continuous link with the ancestors. It becomes important then to appease the dead, who are believed to effect misfortunes if they are not treated right. To wade off misfortunes, certain items are broken on the grave to remove impurity and ill effects of the dead. ${ }^{2}$ Items cherished by the deceased were used for this purpose.

\section{Ngoni}

In the eastern part of Zambia, the Ngoni leave some people at the funeral house while the others go for burial. Their duty is to: (1) prepare food for the mourners to eat when they return and (2) sweep the whole yard, as an act of declaring the end of a funeral gathering and sleeping by the camp fire. Clan cousins, abanungwe, are responsible for all this work. ${ }^{3}$

On the path leading to the grave, a fire is lit and kept burning for the whole time of burial and shortly

${ }^{1}$ Hodder, 196.

${ }^{2}$ Ibid. , 199.

${ }^{3}$ Joseph Mmembe, interview by author, June 19, 1995. 
thereafter, until it dies on its own. After burial, items are brought in from the house and heaped high on the grave. Two skeletons exhumed in Chitembo's village had copper bangles, cloth, and some glass beads, which shows a burial custom of burying with one's wealth. ${ }^{1}$ This goes with the belief that the items could still be used by the dead. In death, therefore, one could bless the living with some of one's wealth.

Lozi

The Lozi culture does not allow the widow or widower to go for burial--he or she is taken later just to be shown the burial place. At the grave, there are no speeches made. As soon as the hole is filled with soil, mourners break a precious item over the grave as a sign of accompaniment. ${ }^{2}$ If a married person dies without leaving children, it is considered a taboo in society. The village head places a piece of charcoal between the buttocks of the deceased and says, azamaye ni mitolo ya hae--"Let him go with his bad

${ }^{1}$ Robin Derricourt, People of the Lakes: Archeological Studies in Northern Zambia (Manchester: Manchester University, 1980), 18 .

\footnotetext{
${ }^{2}$ Kabambe, interview, september 1995 .
} 
luck."1 In case of a village head's death, his body is buried right in the middle of the village. If a prince dies, his grave is enclosed in a small hut. In all cases, mourners leave the burial place and head for the funeral house without looking back. ${ }^{2}$

In this section we see that common only between the Bemba and Ngoni is the practice of letting the bereaved crawl on their hands and knees. The Tonga and Lozi do not practice this. All tribes sing songs of praise and send messages to the ones gone before; they all place some items on the grave for either identity or use by the dead.

While the practice of pointing the head a certain direction is common, the directions differ. The Tonga point theirs to the east, while the others favor west. Distinctive only to the Tonga is walking over the grave and making a fire on it. The Luapula Bembas sing and dance during their mourning. The Lozi are unique in not allowing the bereaved to go to the grave for burial. The Ngoni mourners shave their hairs off while other tribes do not. 1995.

${ }^{1}$ Imasiku Mubita, interview by author, August 12,

${ }^{2}$ Kaluwe, interview, August 28, 1995. 


\section{Post-Burial Activities}

Bemba

For Bembas, the grave diggers and those who touched the dead body are ritually unclean; they are to go to a nearby stream and wash. All others slowly return to the village. A medicine man with prepared medicine for the cleansing meets the mourners on the way. Each mourner is presented with a bowl full of medicated water in which they dip hands and rub themselves all over their body.

Reassembling at the deceased's hut, a meeting convenes, which is known as isambe lya mfwa. This is when a surviving spouse or very close relative to the deceased explains in detail step by step the beginning of the sickness to death. The spouse explains what his or her role was, and the efforts done to bring the sick to health. This assembly is attended by all elderly close relatives. The purpose is to determine the cause of death. If witchcraft is suspected, a n'ganga, spirit medium, is consulted. Early in the morning the following day, elders and close relatives go to the grave site and inspect it for any signs of 
tampering, which would suggest the presence of a witch. One observer puts it this way:

Death was a social rather than a medical event, and one of the most striking communal activities following most moralities was ukusowa banda, the ritual hunt with nets whereby the sex of the first animal killed provides a clue to the person responsible for the death. ${ }^{1}$

A few days after burial, another very important

meeting is convened. This is known as ukufwika imishingo, inheriting the name. Here relatives meet to discuss over who would be suitable among the nephews and grandchildren to be named after the deceased. They look for one with similar characteristics to the deceased or the one the deceased might have appointed before death. The purpose for this is to perpetuate the name of the dead, and this allows the spirit of the deceased to dwell in the heir. Epstein points out that "in the event of death, the central concern of customary law was not with the transmission of tangible wealth, but with the issue of succession."2 To effect name transference, the presiding elder gets the clothing of the

${ }^{1}$ Obayashi, 14 .

${ }^{2}$ A. L. Epstein, Urbanization and Kinship: The Domestic Domain on the Copperbelt of Zambia 1950-1956 (London: Academic, 1981), 90. 
deceased and hands it to the chosen one who immediately is addressed by the new name.

At another occasion, there is a ritual known as ukuwamya or ukusukula iciwa--cleansing. This ritual is "sex intercourse to eliminate the destroying spirit."1 Until the surviving spouse has been "inherited" through sexual intercourse, sexual intercourse with any other is held to be dangerous and remarriage is out of the question. ${ }^{2}$ If a suitable person is not found, a child is made to sit on the lap of the bereaved and rubs impemba, white powder, in the hands saying, "May you be free of our relative's ghost." 3 Several months later, another assembly is called upon for the purpose of ukupyanika. At this time, they remove the mourning clothes from the mourner. At the same time, the relatives may decide to give a new spouse to care for the children and even take over conjugal rights.

$$
\text { Finally a year later, ukupupa is called for. }
$$

Individuals prepare food and beer for a feast known as

${ }^{1}$ Ganley, 27.

${ }^{2}$ Epstein, 92 .

${ }^{3}$ Ganley, 28 . 
icikoloti. This is a form of remembrance when the mourning period is called off $f^{1}$ and the dead called back to participate in the social functions of the community. At this time, the dead are elevated to the status of ancestry. They can be consulted and appeased.

Tonga

The Tonga will, shortly after burial, bring water for all who handled the corpse to wash their hands over the grave. This cleanses them from defilement. Typical Nanzela people had a custom of "pressing a piece of stick to the lips of the grave diggers." 2 This stick is rubbed into the ashes of the grave fire and thrown away with the words, basalale munkumu, that is, "They may be pure to the forehead." 3 This is another way of purifying the grave diggers.

Crucial is the cleansing of the surviving spouse. Kusalazya cleansing is done the night before burial. The

${ }^{1}$ Mrs. Bessie Mushili Mwenya, interview by author, July 16, 1995.

${ }^{2}$ Dale and Smith, 106.

${ }^{3}$ Ibid. 
elders meet in council to determine the eligible person to cleanse the surviving spouse. A clan cousin or nephew is usually the most likely to participate in the sex ritual supposed to cleanse the widow or widower. The chosen and the bereaved are taken to a house. After sex, they go outside where mourners are told that the cleansing was done. This is done in fear of lunyoka, death spirit, that is on the bereaved. This spirit kills anyone who gets involved sexually with the bereaved. One cannot remarry until lunyoka is removed. ${ }^{1}$. The person who cleanses the mourner has the right to marry the widow(er). If he or she decides not to, the mourner is free to marry whomever he or she chooses.

After some time bashimukowa, clan leaders, decide on the date for muyobo ceremonies. This is usually over the weekend when informed relatives gather to decide on a successor for the deceased. Beer is brewed and for several days, there is eating, drinking, music, and dancing. A

\footnotetext{
${ }^{1}$ Ladislav, 152-153.
} 
secret meeting convenes during the night to choose the successor. ${ }^{1}$

The AIDS virus has caused some changes in the cleansing process. Sex is sparingly used. To replace the sexual act, the deceased's underwear is held to the sexual organs of the surviving spouse, which is then placed in the coffin and buried with the deceased. If this is not done, the living spouse is asked to jump over the coffin. In other cases, after burial, cornmeal is given to the surviving person who throws it over the grave. ${ }^{2}$

Six months after burial, another occasion known as mweezyo is convened. Ritual beer is brewed, and people eat, drink, and share the things of the deceased. In some cases, even before burial, relatives of the man who dies grab all his property, leaving nothing for the wife and children. This property taking without the wife's consent or regard happens in most cultures in Zambia. In some cases the widow is mistreated to the extent of being bitten and accused of killing the husband.

${ }^{1}$ Ibid.

${ }^{2}$ Irene Chimoga, interview by author, August 12, 1995. 
Ngoni

The Ngoni will sweep and seal the grave. After burial, ritually-treated water is presented to the mourners to wash off evil spirits they might have contracted at the grave yard. That night they organize muyeni--a ceremonial demonstration of the deceased's occupational activities. During this same time, a widow or widower is forced to crawl around the house on the knees and hands. ${ }^{1}$ Men dressed in ghost costumes called nyau dancers, representing the spirits, go to the grave and start singing and dancing their way to the village. This is to scare away evil spirits. They continue singing and dancing the whole night. ${ }^{2}$

Early in the morning, elders go to the grave and look for the footprints of a hyena, which is taken to be an indication of a witch's involvement in the death. A few days later, the kugela ritual starts. Here all the clan relatives of the dead cut their hair short. All the hairs are gathered into one bundle and burned at the dumping place. At a convenient time, the relatives of the deceased

${ }^{1}$ Mmembe, interview, June 24, 1995.

${ }^{2}$ Ibid. 
meet to talk about the welfare of the widow(er) and the children. They also consider taking off the mourning clothes and declare the mourning period over. At this meeting, the bereaved is made to sit on a plain reed-mat, showing openness, and then gives an explanation of the sickness and death of the spouse. After this, the mourning clothes may be taken away from him or her and the person is declared free to go and marry whomever one may choose. In order to preserve the name of the deceased, a person is selected who is given one item of great value such as a gun, axe, or hoe.

$\underline{\underline{L O z i}}$

The Lozi mourners would upon arrival from the burial place, wash their hands in one bucketful of treated water, to spell out the demons. This water is later poured over the grave. Another cleansing ritual is done for the close relatives. Right after burial, a traditional medicine man or spirit medium comes in with some boiled roots and barks of selected herbal trees. In this concoction, he dips a broom and sprinkles the liquid over the relatives of the deceased. From that time, the bereaved, who have been in 
seclusion most of the time, are free to mingle with the people and go the relatives. ${ }^{1}$

Later, after a short stay, the mourners scatter to their homes, leaving the close members of the family to decide what to do with the property. Property is shared equally among children and close relatives. The name of the deceased is given to one of the children who is to be born in any close family. To determine whether the spirit of the dead has accepted the heir, the child either cries a lot, as a sign of rejection, or is calm for acceptance. In case of rejection, the spirit medium is consulted to verify this before another name is chosen for the baby. ${ }^{2}$

This portion of the study points out that all four tribes in Zambia have a similar cleansing ritual. Cleansing is done in various ways. The Tonga, Bemba and Ngoni use sexual intercourse, while the Lozi use a n'ganga, with ritually-treated water to cleanse the living of the evil spirit.

${ }^{1}$ Kaluwe, interview, August 28, 1995.

${ }^{2}$ Kabambe, interview, september 2, 1995. 
Property distribution is done with consideration of the widow and the children of the deceased only in the Lozi culture. The other tribes have the relatives ruthlessly take the dead man's property, leaving the widow and children without anything. Although the widow is not given property, she is cared for through levirate marriage.

\section{Summary}

The beliefs discussed were the seedbed for funeral practices in Zambia. It is evident that the funeral practices are to a considerable degree the result of the influence of beliefs that have to do with spirits. All tribes believe in the spirits' influence. It can be ascertained that early people movements, wars, and trade led to a mixing of cultures, beliefs, and practices. Although there are some differences in cultures, the principles behind the rituals are more alike than they are different.

The tribes of Zambia believe in the survival of the soul. That is why burial with due rites and ceremonies is regarded as an important concern--for the departed and for those living. Unless the deceased is properly buried, and provided with the usual offerings, the soul is believed 
unable to find rest. This results in a wondering spirit, dissatisfied and unhappy. This in turn is believed to be a danger to those living. There is therefore a close relationship between the departed and the living.

Several elements are found to be common among all the tribes. The first is the wearing of mourning attire and changing the appearance radically from the everyday look. This includes not shaving and taking a bath. It is observed that the general color accepted for the mourning dress is black. The reason for this mourning garb may be to please the ghost, in that people express the idea of being dead than alive. Another is the possibility that by so doing, the attention of the ghost is diverted. The ghost does not recognize those wearing black or looking untidy. The most likely reason is that it is the way the bereaved express their grief and perturbation.

The second element is the extreme sorrow shown by close relatives in putting dust on themselves, slamming themselves to the ground, and causing pain to themselves. All this is done either to show extreme sorrow or to appease the envy of the deceased. This may also be a way to appease the relatives of the dead so that one may not be implicated 
in the death of the relative. For if any sign of lack of care is noticed, it is followed by a wave of torture from the relatives of the deceased.

Third is the cleansing that is done in various ways. The most controversial of these involves sex. Other cleansing rituals may not be talked about as much, but they express a belief in spirits coming back to haunt the living. Fourth is the mistreatment of the bereaved.

Whenever there is a death in the family, it is treated as umulandu--a case. The spouse is a suspect as well as all who may not have been on good terms with the departed. All remain suspects until the case is discussed and concluded or they are cleared by a diviner. This mistreatment is worse on women who are left without any property they had toiled for with the husband.

Fifth is the insistence that the head of the person being buried face a certain direction. In all tribes, a direction provides rest to the deceased, otherwise the deceased does not rest well. While it is believed that the dead gets involved in the functions of the society, they also believe that the dead rests in the place where the ancestors orignated. 
Issues Raised

From the discussion in this chapter, it is clear. that Adventist Christians are faced with issues that need attention with some biblical support.

First, are the dead able to exist as spirits that control cosmic powers and hurt the living? Are they able to protect those in harmony with ritual practices of appeasing them?

Second, why do so many Christians get involved in ritual cleansing that involves sexual intercourse? Can the church tolerate ritual cleansing because it is cultural? Does the cleansing really have an effect?

Third, is it justifiable for family members of the deceased to let the bereaved pass through humiliating and torturesome activities associated with spirits? Are these activities necessary?

Fourth, is there justification in taking all the property of the deceased, leaving the widow and the children with nothing?

Fifth, are spirits really called back into the social functions of the society? What is behind spirit 
possession? Why do they bring more evil than good if they are protective ancestors?

Sixth, can there be justification in insisting that the head of a corpse face a certain direction? Are family burial grounds important?

Seventh, in the light of what Christ did when in contact with spirits, what should Adventists do when they encounter spirit forces? Should power encounters be called for?

Eighth, should there be a Christian funeral liturgy? Is there a biblical approach to funeral rituals?

These are some of the questions that need to be answered in the chapters to follow. 
CHAPTER 3

THE BIBLICAL UNDERSTANDING OF DEATH

AND DEATH RITUALS

Chapter 2 dealt with various beliefs and practices of four major tribal groups in Zambia. Issues surfaced that need attention in this chapter and the chapters to follow. One obvious question arising from the practices described above is: What happens when a person dies? This chapter answers this question from the biblical standpoint.

This chapter addresses the issues in two major sections. The first section looks at how the old Testament views death. This is done in three parts. Part one describes the rituals performed after death, at burial, and after burial. Part two analyzes words associated with death. Finally, part three focuses on one selected text that sheds light on the issue of death and funeral practices in the old Testament.

The second section looks at the New Testament view of death. It follows the same pattern as done in the first 
section. Part one describes rituals as the New Testament Scripture unveils. Part two analyzes the Greek words often used in translations to support the idea of the immortality of the human person in a different form. Finally, part three analyzes one selected text to find out if there is support for the idea of ancestors living after they are physically dead and buried.

These sections are put together to show the biblical understanding of death rituals and life after death. An accurate understanding of this gives rise to a correct analysis of traditional views in the light of Scripture.

\section{Death Rituals in the old Testament}

Between death and burial, the kind of treatment provided for the deceased demonstrates the living's respect for the dead. The extraordinary treatment accorded to a Iifeless body by family members reflects their view of what the body was before death--the temple of the holy spirit.

It has been observed that "burial customs among the Hebrews consisted of two important elements: the mortuary ritual, which accompanied the burial, and physical 
preparation of the body and its final resting place."1

While the complete mortuary ritual among the Hebrews is not described in the Bible, most elements are represented in a variety of passages.

\section{Pre-Burial Activities}

As soon as signs of death are fully developed, the eldest son or nearest relative present closes the eyes of the dead (Gen 46:4). The body is then prepared and laid in a room (1 Kgs $17: 19 ; 2$ Kgs 4:21); wailing and weeping commence as soon as news is broken to people ( 1 Kgs 13:30; Jer 9:17-18; Mic 1:8; 2 Sam 1:12). At this moment, as a physical sign of grief, the Hebrews gave inspired symbolic expression to their grief by rending their garments and putting on sackcloth (Gen $37: 34 ; 2$ Sam $13: 31 ; 14: 2$; and Isa 20:2). Cloth rending "is an opportunity for psychological relief, it satisfies the emotional need of the moment, or else it would not be permitted as it is a clear violation of the Biblical command not to cause waste."2 Rabbi Weiss in

${ }^{1}$ Harper's Bible Dictionary (1985), s.v. "Burial."

${ }^{2}$ Maurice Lamm, The Jewish Way in Death and Mourning (New York: Jonathan David, 1969), 38. 
support of this tradition adds, "So effective is the tearing of our garments as the visible sign of our broken hearts that our sages ruled out any compromise on this expression of our mourning."1

Commenting on Gen 36:34-35, Westermann looks at tearing of garments and putting on of sackcloth as customs "so old and widespread that their meaning can no Ionger be determined."2 However, willis agrees with Weiss that rending one's garment and lying on the ground were symbols of grief. ${ }^{3}$ When Job learned about the death of his children, not only did he tear his robe, he also shaved his head (Job 1:20). Shaving hair off is not a condemned act. As an expression of humility, it was called for by the Lord (Isa 22:12; Jer 7:29; Mic 1:16). The external tearing of a garment is an indication of the "broken heart" within (Job $2: 13)$

${ }^{1}$ Rabbi Abner Weiss, Death and Bereavement: A Halakhic Guide (Hoboken, NJ: Ktav, 1991), 66 .

${ }^{2} \mathrm{Claus}$ Westermann, Genesis 37-50: A Commentary (Minneapolis: Augsburg, 1986), 44.

${ }^{3}$ John T. Willis, The Living Word Commentary: First and Second Samuel (Austin, TX: Sweet, 1982), 360. 
Weeping and eulogizing flowed freely (Gen 50:10) as friends and relatives gathered to offer condolences (Gen 37:35). The preacher mentions that it is better to go to the house of mourning than the house of feasting (Eccl 7:2), an indication that it was a common practice to gather at funeral houses and support those mourning. As people gathered, it is apparent that people sang and played traditional mourning songs. A closer look at the songs recorded reveal that they were songs of praise for the deceased (2 Sam 1:17-27; 3:33-34; Jer 9:20-22).

\section{Burial Activities}

Jewish law establishes uncompromisingly that the dead must be buried in the earth. God's word to the first couple after they sinned was, "for dust you are and to dust you will return" (Gen 3:19). Later it became a law to bury any person with soil after death (Deut 21:23). Burial of the deceased was expected to take place the same day, or within twency-four hours (Deut 21:23). Sperling gives a reason for early burial when he writes, "Death, Judaism 
teaches, atones for the sin of man, therefore the body should at the earliest moment be laid to rest."1

Proper burial required a burial place. The first and important preferred area was the sepulchre in the family land. Recorded old Testament stories about patriarchs tell us that family members were buried together in a cave located on a family-owned land (Gen 47:30; 49:29). Family tombs were respected. The Bible records the burial locations of ancestors like judges, prophets, kings, and other distinguished individuals were rock-hewn cliffs (2 Kgs $23: 16 ; 2$ Chr $16: 14$; Isa $22: 16$ ).

Abraham insisted on purchasing a burial ground called Machpelah. In this cave many family descendants were buried (Gen 47:29-30; 49:29-31; Exod 13:19). In such family grounds, family member after member was buried in a benchlike grave in such cave tombs. At the time of Judges, Gideon, Samson, and Asahel are known to have been buried in their ancestral tombs on family land. ${ }^{2}$

${ }^{1}$ Abraham I. Sperling, Reasons for Jewish Customs and Traditions (New York: Bloch, 1968), 292.

${ }^{2}$ Elizabeth Bloch-Smith, Judahite Burial Practices and Beliefs about the Dead (Sheffield, England: JSOT, 1992), 115 . 
After a year, "bones were likely gathered to a common area to make room for those who died later."1 Burial in family tombs "insure and demonstrate a visible, perpetual claim to the land."2 Gibson mentions that "Hebrews looked forward to a peaceful death in old age, when their bodies would be buried beside those of their forbears." ${ }^{3}$ Those who accomplished this were considered blessed and approved of God .

Apart from rock-hewn tombs, some graves were dug in the ground under trees; this is where Deborah was buried (Gen 35:8). Generally, however, commoners were buried in pit graves (Deut 21:23). These burial grounds, pit graves, and caves, were situated away from residential areas. This necessitated transporting the body to the tomb. The body was carried on a wooden bier by friends and relatives

(2 Sam 3:31). Along went a mixed multitude accompanying the body for burial ( $1 \mathrm{Kgs} 13: 29,30 ; 2 \mathrm{Kgs} 23: 30$ ). Among them

${ }^{1}$ Allen Page, Life after Death: What the Bible says (Nashville: Abingdon, 1987), 26.

${ }^{2}$ Bloch-Smith, 115 .

${ }^{3} J o h n$ C. L. Gibson, Genesis, vol. 2 (Philadelphia: Westminster, 1982), 132-133. 
were professional mourners who played and sang lamentations for the occasion (Job 21:32-33; Eccl 12:5; Jer 9:17; Amos $5: 16)$

Archaeological investigations have determined two major types of burials among Israelites: a temporal and a permanent one. ${ }^{1}$ A body or skeletal remains could, after a period of time, be moved from a temporary burial place to another site more permanent (2 Sam 21:12-14). After the primary burial was complete, aromatic spices were placed in the tomb (2 Chr 16:14). These spices were placed there to combat the smell of putrefaction. ${ }^{2}$

At Asa's funeral, a huge fire is mentioned whose significance is a memorial and honorific rite customarily granted to kings. ${ }^{3}$ The festivities connected with Asa's entombment reflect the esteem in which he was held by the people. The historic origin of such fires for the dead is not known; ${ }^{4}$ however, Jeremiah's mention of God's promise to

${ }^{1}$ The Eerdmans Bible Dictionary (1987), s.v. "Burial."

${ }^{2}$ Ibid.

${ }^{3} \mathrm{~J}$. A. Thompson, The New American Commentary: $1 \& 2$ Chronicles, vol. 9 (N.p.: Broadman \& Holman, 1994), 276. "Sara Japhet, 1 \& 2 Chronicles (London: SCM, 1993), 739. 
Zedekiah concerning his funeral seems to indicate that funeral fires in honor of kings was a recurrent phenomenon (Jer $34: 5)$.

After burial, the funeral was far from ending. Activities for comforting and caring for the bereaved continued. The following section describes some of the activities the Bible mentions. These activities differ as time after burial elapses.

\section{Post-Burial Activities}

Weeping and mourning did not end after burial. The period of seven days of intense mourning for a closest relative is mentioned (Gen 50:10). During this period, the mourner emerges from the stage of intense grief, which is between death and burial. The first few days are so intense that no talking is allowed (Lev $10: 3$ ). It is a period of silent grief (Amos 5:13; Lam 3:28). There is not even the greeting of peace extended to the mourner (Ezek 24:17) because the soul is not at peace when one is in grief. In some cases mourning was extended for more than seven days. When Moses died, Israel grieved for thirty days (Deut $34: 8$ ). Aaron was also mourned thirty days (Num 
20:29). Jacob's mourning period was the longest--it took seventy days including forty days of embalming (Gen 50:3).

Embalming was an Egyptian cultural practice that Israel might have assumed while in Egypt.

The mourner and those coming to pay condolences sit on the ground or very low stools (Job $2: 13$; Neh 1:4). When Ezekiel's wife died, the Lord told Ezekiel to react radically different. His behavior was to be the opposite from the way he behaved in a normal funeral situation. By implication, during a funeral people shed tears, weep, mourn, remove shoes, cover the lower part of the face, and eat customary food brought for the mourner (Ezek 24:17; Jer 16:7). This mourning meal was intended to comfort and help ease the sorrow of the bereaved.'

Joab's counsel to a Tekoan woman in pretending to be in mourning reveals some more rituals done during the mourning period. They had a particular dress code and did not use cosmetics (2 Sam 14:2). The bereaved were to refrain from shaving and grooming themselves.

${ }^{1}$ Emmanuel Fieldman, Biblical and Post-Biblical Defilement and Mourning: Law as Theology (New York: Ktav, 1977), 84 . 
Forbidden Practices

As the Hebrews settled in the promised land, the surrounding heathen nations had a tremendous impact upon them. These heathen nations practiced certain death rituals that were condemned by God because they contradicted the normative faith of Jehovah God. Horn suggests, that the Hebrews borrowed and practiced some of the ways God condemned. ${ }^{1}$ When Israel would conquer the land, the people were not to learn the detestable practices and ways of pagan nations. God was trying to make a distinction between those who believe in Yahweh and those who do not.

Divination and consultation of mediums were some of the forbidden practices (Deut 18:10). Forbidden also was cutting themselves (Lev 19:27-28; 21:5; Deut 14:1-2), but among Canaanites, mourning included cutting and mutilating one's flesh for the dead (Jer 16:6). Such practices were found among Baal worshippers (1 Kgs 18:28), and were at variance with the worship of Yahweh and incompatible to holiness (Deut $14: 1,2$ ). This cutting of self (Jer 41:5),

\footnotetext{
${ }^{1}$ The Seventh-day Adventist Bible Dictionary (1979), s.v. "Mourning."
} 
offering food to the dead (Deut 26:14), and eating the tithe at funerals were expressly forbidden. ${ }^{1}$ The Bible does not specify why such practices were forbidden apart from the fact that they were not liked by God. But since such practices were found among heathens, it may have been to make a distinction between God's people and others. Priests were not allowed to keep their hair unkempt, nor shave and cut their bodies during mourning (Lev 21:5). Believers, Goldberg adds, "should have absolutely nothing to do with the occult, believers should rely on what God has revealed in the word." 2 This prohibition was necessary because pagans believed death to be a mere gateway to another world of spirits of the dead. ${ }^{3}$ Brown adds that these "evil rites were the cause of God's judgement on Canaan. It cannot be right for any believer to indulge in practices which God despises." 4

${ }^{1}$ Gerhard Von Rad, Deuteronomy (London: SCM, 1988), 160.

${ }^{2}$ Louis Goldberg, Deuteronomy (Grand Rapids: Zondervan, 1986), 109-110.

${ }^{3}$ G. A. F. Knight, Leviticus (Philadelphia: Westminster, 1981), 133 .

${ }^{4}$ Raymond Brown, The Message of Deuteronomy (Downers Grove, IL: Inter-Varsity, 1993), 184-185. 
Beyond the Mourning Period

After the mourning days were over, the Jews made provision for the widow and her children. The family law custom of the levirate is found only three times in the old Testament, in Gen 38:8, Ruth 2:20, and Deut 25:5-10. The primary purpose was to raise children so that the name of a deceased would not be blotted out of Israel (Deut 25:6; Gen 38:8). It had only a secondary purpose of passing the property on to the heir. It was the responsibility of caring for the bereaved that was the reason for the levirate (Deut $25: 6$ ).

In the event of property distribution, the property went to the heir, the son. In the absence of a son, it went to the widow, then daughters. If there were no daughters, then the father took the property. Brothers-in-law were next in line, otherwise, the nearest next of kin took it (Num 27:5-11). If the widow married an outsider, that is, one not in the husband's family line, this new husband became the legal heir. The concern of Deut 25:5 is to prevent just such an outsider from entering the picture. ${ }^{1}$

${ }^{1}$ Don C. Benjamin, Deuteronomy and City Life (New York: University Press of America, 1983). 254, 246. 
In a normal situation, a brother of the deceased took the widow for a wife. If the brother did not want to take the widow for a wife, there was a religious procedure of releasing the widow so that she could marry any other man. The widow freed the brother-in-law by removing the shoe from his right foot and spitting on the ground in front of him (Deut 25:9).

It is important to note that Tamar (Gen 38) and Ruth (Ruth 3:6-15) sought for an heir, not purification, by sexual intercourse (Deut 22:13-21). In the levirate marriages, the brother-in-law was allowed intercourse with his sister-in-law. Other obligations involved were financial, the management of the deceased's property, and to grace the widow with the social status of a married woman (Gen 38: 26ff.). Those revolting against the levirate responsibility were punished severely (Gen 38:9, 10).

\section{Analysis of Key Terms}

This part of the study is related to the preceding section concerning death rituals practiced in the old Testament. Since this chapter is dedicated to a biblical understanding of death in the old Testament, a careful study 
of related terms sheds meaning on the old Testament understanding of death. Three key terms discussed are "sleep," "soul," and "spirit." Hebrew terms that are translated into English sometimes pose problems. The profound difference in belief systems held by English and Hebrew speakers precipitates into the translation of words that eventually reflects beliefs quite unlike those usually attached to the Hebrew terms. ${ }^{1}$

Death as sleep

Death is frequently called sleep. Kings of Israel and Judah after death were referred to as sleeping or resting with their forefathers (1 Kgs $2: 10 ; 11: 43 ; 14: 20,31$; $2 \operatorname{Chr} 21: 1 ; 26: 23$ ). Job referred to death as sleep (Job 7:21; 14:10-12). Even the psalmist, Jeremiah, and Daniel saw death as sleep (Ps 13:3; Jer 51:39,57; Dan 12:2). Sleep fits the symbol of death because the condition of a person in sleep is identical to the condition in death. The Seventh-day Adventist Bible Dictionary makes a comparison between sleep and death. In sleep as in death there is

\footnotetext{
${ }^{1}$ The Perennial Dictionary of World Religions (1989), s.v. "Soul, Spirit."
} 
unconsciousness of the mind (ECCl 9:5). Cognition is dormant (Ps 146:4), there is no work (Eccl 9:10), and emotions of love, hate, and jealousy are inactive (Eccl 9:6). As in sleep, there is no praising God in death (Ps 115:17). Sleeping presupposes awakening; death also presupposes a resurrection (Job $14: 15$, Dan 12:2). ${ }^{1}$ Death is but a short rest after which activity resumes. The psalmist had confidence in God's ability to keep His covenant. He hoped in salvation from death, which is a resurrection (Ps 16:11; $49: 15-16 ; 73: 23-26)$. Life beyond the grave is possible only as the resurrection comes to reality (Ps $89: 48,49$ ).

McAlpine's study on sleep in the Old Testament agrees that the sleep/death juxtaposition is as much a symbol of their common elements. ${ }^{2}$ As in sleep the dead have no influence on those living, which is a fitting conclusion for this part of the study.

Words often used to support the idea of the dead still existing in some form are soul and spirit. The next

\footnotetext{
${ }^{1}$ The Seventh-day Adventist Bible Dictionary (1979), s.v. "Death"

${ }^{2}$ Thomas H. MCAlpine, Sleep. Divine \& Human, in the old Testament (Sheffield, England: JSOT, 1987), 149.
} 
segment of study analyzes these words in their original Hebrew usage to find out if they support or reject this understanding.

\section{Soul}

The examination of the word "soul" leads us to an understanding of whether in man there is an entity that leaves the body and continues to live apart from the body, qualifying to be called an ancestor. Does the word "soul" in its many appearances in the old Testament carry an implication that it continues to live after death?

In the old Testament, the Hebrew word for soul, nephesh, appears 755 times. It comes from the root word naphas, which means to revive oneself or to refresh oneself. ${ }^{1}$ The word nephesh in its primary usage means living being, life, person, that which breathes, the breathing substance, or being. ${ }^{2}$ Nephesh is usually used to describe a person who is alive. ${ }^{3}$

${ }^{1}$ Francis Brown, ed., The New Brown, Driver, Briggs, Gesenius Hebrew Aramaic English Lexicon (Grand Rapids: Baker, 1981), 661.

$$
\begin{aligned}
& { }^{2} \text { Ibid., } 659 . \\
& { }^{3} \text { Page, } 23 .
\end{aligned}
$$


The word nephesh "does not mean soul in the strict sense as a separate entity, but the whole human being."1 There are other uses of the word nephesh in the old Testament. Ellis Robert Brotzman studied the plurality of the word. He shows that in some passages of scripture it is translated "person" (Gen 14:21; Num 5:6;). In other places it is translated "self" (Lev 11:43; $1 \mathrm{Kgs} \mathrm{19:4).} \mathrm{It} \mathrm{comes}$ also as desires, passions, or appetite (Deut 23:24; Prov $23: 2 ; \operatorname{Eccl} 6: 7 ; \operatorname{Prov} 23: 2 ; \operatorname{Eccl} 6: 7)$. It is also used as "emotions" (1 Sam 1:15), "pleasure" (Psm 105:22; Jer $34: 16) .^{2}$ In all its appearances, there is no notion that soul has an independent existence. ${ }^{3}$ "Man is not an incarnate soul but animated body," 4 he is a physical being whose

${ }^{1}$ Hans Schwarz, Beyond the Gates of Death: A Biblical Examination of Evidence for Life after Death (Minneapolis: Augsburg, 1981), 25.

'Ellis Robert Brotzman, "The Plurality of 'Soul' in the Old Testament with Special Attention Given to the Use of 'Nephesh'" (Ph.D. Dissertation, New York University, 1987), 233 .

${ }^{3}$ Francis Wright Biare, The Gospel According to Matthew (San Francisco: Harper \& Row, 1982), 248.

${ }^{4}$ Paul Badham, Christian Beliefs about Life after Death (London: MacMillan, 1976), 3 . 
earthly life is bound up with the existence of the body. A human being does not have a nephesh, soul, he is the soul.

The term "soul" is not limited only to human beings, animals are also souls (Gen 1:20). In its 755 occurrences, the word soul is 119 times translated "life," and in other translations, there are places in which nephesh was translated differently where "life" would have been a better translation. The soul, therefore, is not able to continue its existence outside the body. Scripture shows clearly that a soul can die (Ezek 18:4; Num 31:19; Judg 16:30). For this reason, soul in some cases refers to the dead (Lev 19:28; Num 9:7, 10). In conclusion, no one has a soul, everyone is a soul.

$$
\text { Spirit }
$$

Another key word to clear the misunderstanding about the state of the dead is ruach. In the old Testament this word appears 377 times. It has a variety of meanings and translations. Only the context determines an accurate translation and meaning. It is, however, translated as wind (Judg 15:19) or breath. This word is also used to describe the living principle in men and animal. Other times it is 
translated "morality" (Ezek 11:19), "courage" (Josh 2:11), and "anger" or "resentment" (Judg 8:3).

The primary meaning of the word ruach is the spirit of God, the animating principle of all that lives. ${ }^{1}$ Both man and animal come to life because God breathes into them His own breath. Schwarz sees ruach to be the "seat of emotions and of intellectual functions."2

In the old Testament, Swartz continues, "spirit was perceived as God's comprehensive enabling, enlivening and sustaining power." 3 Looking at the word itself, ruach "refers to the energizing spark of life, essential to individual existence. It stands for the divine energy or life principle that animates human beings."4

Spirit is never in its 377 appearances referred to as an entity capable of living on its own, separate from the body. $\quad$ Ruach and nephesh are two separate words addressing different issues. Nephesh is a combination of body and

${ }^{1}$ Ibid.

${ }^{2}$ Schwarz, 27 .

${ }^{3}$ Ibid. , 28 .

${ }^{4}$ Seventh-day Adventists Believe (Hagerstown, MD: Review \& Herald, 1988), 83. 
spirit, ruach is the breath of life that gives life to the body $\cdot^{1}$

This spirit, which is the breath of God, brings Iife (Gen 2:7) and understanding (Job 32:8). Death is the result when God takes back His spirit--ruach (Job $34: 14$; Eccl

12:7). This spirit that goes back to God is not just simple air or wind, it is the creative power of God that He used in the creation of the world and $\operatorname{man}$ (Ps $33: 6$ ). The word of the Lord and the breath are used as one and the same thing in creation.

old Testament people realized remarkably well that life depends on God and His creative power. Since nothing can live unless supported and sustained by God's life-giving spirit, life beyond the grave is only what God can give, not what is inherent in man.

Therefore, the word ruach, spirit, does not suggest Iife in an invisible form. The old Testament does not support the idea that man possesses a separate entity that

${ }^{1}$ Senzo Nagakubo, "Investigation into Jewish Concept of Afterlife in the Beth She'Arim Greek Inscriptions" (Ph.D. dissertation, Duke University, 1974), 108. 
survives after death. ${ }^{1}$ It does not support either the idea that the Devil is able to capture spirits of the dead and use them as malevolent ones. At death, the old Testament shows that God takes back His sustaining power (Eccl 12:7) and when man would survive death it has to be as a whole being. The idea of soul and spirit used to describe the form of man's survival immediately after death is a later development coming with the Greek culture. ${ }^{2}$ It is an invention of the human mind, not God's plan.

\section{Textual Analysis}

In this section Jacob's request in Gen 49:29-33 and what the verses say was done to him are considered exegetically. The purpose is to find out if this and other similar verses that use the same expression indicate that ancestors and those who die existed in some place? Do these verses support ancestral veneration or ancestral worship? Can African traditionalists use these verses to support the belief in ancestral spirits? These are some of the questions we need to address and find possible answers to.

\footnotetext{
${ }^{1}$ Weiss, $13-14$.

${ }^{2}$ Nagakubo, 108 .
} 


\section{Possible Interpretations}

Gen 49:29, 33: "I am about to be gathered up to my people. Bury me with my fathers in the cave in the field of Ephron the Hittite. . . Jacob breathed his last and was gathered to his people."

This expression is given in reference to six people only: Abraham (Gen 25:8), Ishmael (Gen 25:17), Isaac (Gen 32:29), Jacob (Gen 49:33), Aaron (Num 20:24), and Moses (Deut 32:50).

\section{First Interpretation}

Does this expression mean being buried in the same tomb of the forefathers? Some have deemed this to be so. George Mendenhall says, "Gathered to his ancestors is a conventional phrase that doubtless derives from the fact that the body was placed in the family tomb, where the bones of the ancestors already lay."I Others like Page add, "These descriptions suggest an emphasis on a common familial burial site, such as described in Machpelah as the burial place for Sarah." 2

1Obayashi, 68-69.

${ }^{2}$ Page, 23. 
This interpretation has some problems to solve. When the phrase was first used in reference to Abraham in Gen 25:8 the family tomb that Abraham had purchased had only his wife buried there. No other person was ever buried there--the Machpelah tomb had no bones of ancestors or relatives apart from his wife. It is unlikely that "he was gathered to his people" was referring to his wife. It seems there is another meaning we should look for. Bloch, not in support of family tomb burial, says this expression is tantamount to simply burial. ${ }^{1}$

Looking at Moses' death, however, we find the expression used in Deut 32:50: "there on the mountain that you have climbed you will die and be gathered to your people, just as your brother Aaron died on mount Hor and was gathered to his people." If this expression means being buried in the family tomb, or simply bury, then it has to explain the fact that Moses was not buried in his father's tomb, the people did not bury him at all and nobody knows where God buried Moses (Deut 34:6). To conclude, the 
expression under consideration does not mean being buried in the family tomb.

\section{Second Interpretation}

The second possible interpretation is that those who die join the company of the other spirits that died before and live together as disembodied spirits in a spiritual realm. There are many who believe that when people die, they live on as disembodied spirits and that they are in some ways involved in the affairs of this world. This is what makes them ancestors or ancestral spirits. Does the expression "gathered up to his people" mean disembodied spirits?

The Hebrew word from which this expression comes is ne'esaph. It comes from the root Hebrew term asaph, which means to gather, to remove, to take away, to draw. ${ }^{1}$ From this root comes a connotation of gathering an individual into the company of others. Association, responsibility, and protection are implied. It seem to denote that those who die change into some form that is able to join other 
spirits who have the ability to receive newcomers. The question is, Do we find biblical support for this?

The root word does not have anything to do with spirits. The rest of the Bible has a message quite different from this. The Bible declares that the dead are dust and cannot praise God (Ps $6: 6$ ), those in sheol cannot praise God (Ps 30:9). If the dead cannot praise God, it means they, do not live on. They, therefore, do not live in a special place (Ps 146:4), they know nothing of what is happening here. Therefore, they cannot have any involvement in the affairs of this world (Eccl 9:5).

\section{Third Interpretation}

The third possible interpretation is that this expression is a common Hebrew figure of speech used to mean "to die." God told Abraham, "You will go to your fathers in peace and be buried at a good old age" (Gen 15:15). Could this simply mean Abraham would die? Looking at Gen 25:8 carefully when his time to die came, the sequence is shown as (1) Abraham breathed his last, (2) died at a good

"Genesis," The SDA Bible Commentary, ed. F. D.

Nichol (Washington, DC: Review and Herald Pub. Assn., 1976), 1:315. 
old age, (3) he was gathered to his people, and (4) in vs.9 his sons buried him. Dying and being gathered to his people seem to be separate and different, not one and the same thing--otherwise they would not appear in that order. Referring to Isaac, this sequence again is mentioned. He (1) breathed his last, (2) died, and (3) was gathered to his people. This sequence does not seem to be a repetition of dying. There seem to be three different phases being mentioned that are close to each other. Breathing his last is the first phase of death, dying seems to be the second phase, then being gathered is the third, which comes just before being buried, the fourth stage. With this, the study concludes that the expression does not simply mean "to die."

\section{Fourth Interpretation}

The other interpretation of this expression is that it means to descend to sheol. Mendenhall puts it this way: "When people die, they descend to sheol, which can only be defined as the place where the dead are dead."1 The word sheol suggests what happens after death. Some have traced the etymology of the word to focus on "hallowed" place.

'Obayashi, 70 . 
Sheol is the realm of the dead. It reflects an uncertainty of what happens at death. In sheol there is complete silence (Job 7:8-9; Pss 6:5; 30:9) Isaiah describes sheol (Isa 14:11) and Badhan summarizes it well that sheol "is a poetic description of the dead in their graves." 1 The ancestors were gathered to their fathers in the abode of the dead, sheol, a place for all the departed, regardless of their moral or spiritual stand. In there they led a shadowy existence with no contact with the divine or humanity.

"Sheol was little more than a poetic expression for the common grave, the universal tomb of the earth that awaits us all."2 In this sense, asaph, to take in or to gather in, means that to be gathered to his people would be to join the dead. These dead are not living somewhere, they are dead; they have joined the dead. Therefore, the three-fold sequence becomes even clearer: (1) he breathed his last, (2) died, and (3) joined those who died before--that is, joining them in being unconscious.

${ }^{1}$ Badham, 4 .

'John P. Meier, "Catholic Funerals in the Light of Scripture," Worship 48, no. 4 (1974): 207. 
Second, this expression is used only on people who died at a ripe old age and to the ones who had hope and faith in God, and looked forward to resurrection. The phrase "his people" refers to the people of "his kind" who had faith and the hope of future deliverance and to be at peace in the home prepared by God. ${ }^{1}$ This expression is never used of evil people and those who meet death violently (Judg $2: 10$ ).

To sum it up, "being gathered unto his people" is an expression that points to the future hope of being in the company of those who will live in the life to come, a happier existence. ${ }^{2}$ Therefore, those being gathered to their people do not only join the dead, in the realm of the dead, but they await the fulfillment of God's promise of deliverance, the resurrection.

\section{Death Rituals in the New Testament}

Death rituals in the New Testament were not different from those practiced in the old Testament. As in

${ }^{1}$ William Wilson, The New Wilson's Word Studies (Grand Rapids: Kregel, 1987), 182.

${ }^{2} \mathrm{H}$. C. Leupold, Exposition of Genesis (Grand Rapids: Baker, 1953), 695 . 
the OT, death was regarded as a historical event marking the end of a person's existence. The rituals practiced in the old Testament were carried through into the New Testament period. The basic difference lay in the New Testament emphasis on resurrection.

\section{Since there is basically no difference in the} practices from those done in the old Testament, this section briefly summarizes the pre-burial, burial, and post-burial activities as seen in the New Testament passages.

\section{Pre-Burial Activities}

Death was announced by a shrill voice, followed by a tumult of lamentation (Mark 5:38). Friends and relatives gathered for the funeral. Among these were the hired mourners and flute players (Mark 5:38; Matt 9:23). ${ }^{1}$ Singing was part of the funeral ceremony even in New Testament times.

The body of the deceased was washed (Acts 9:37) and anointed with oil (Mark 16:1; Luke 24:1; John 12:7; 19:39, 40). "It seems to have been the burial custom of the Jews to

${ }^{1}$ Ellen G. White, The Desire of Ages (Boise, ID: Pacific Press, 1940), 343 . 
treat a body with myrrh and aloes."I The body was then wrapped in linen cloth (Matt 27:59; John 11:44) with the mouth bound shut (John 11:44) and laid in the room (Matt $9: 23$; Acts 9:37), waiting for burial.

\section{Burial Activities}

When all the preparations had been made, the corpse was lifted onto a bier (Luke 7:12-14), which was then carried by shoulder to the tomb. The tombs were situated away from residential Palestinian towns. ${ }^{2}$ Mourners accompanied the bier all the way to the burial place (Mark $^{3}$ $6: 29 ; 14: 12)$

Burial was to be done within twenty-four hours after death (Acts 5:5-10); "haste is required because of the rapidity of decomposition, the excessive violence of grief, a reluctance to allow the dead to remain long in the houses of the living."4 Perhaps the fear of defilement by contact with the dead was another reason (Num 19:11-16) Even Jesus

${ }^{1}$ SDABD, 167, s.v. "Burial."

${ }^{2} \mathrm{~J}$. B. Payne, "Burial," The International Standard Bible Encyclopedia (1979), 560 .

${ }^{3}$ White, The Desire of Ages, 318.

${ }^{4}$ Ibid. , 556. 
was not allowed to remain hanging on the cross after He was dead (Matt 27:57-59).

As for the grave, for majority of Israelites who could not afford the expensive rock-hewn tombs, their burial consisted of being placed in the ground. After lowering the body down into the ground, "the bier, of course, was set aside; and the earth replaced, followed by a heap of stones to preserve the dead from depredations of beasts or thieves."1 For a long time, the Jews practiced the custom of moving the bones from one area of the tomb to another, after the body had fully decomposed and bones were lying loose. Bones would be piled in one area or put in a box and placed on a shelf. According to McCane this explains Jesus' saying, "let the dead bury their own dead" (Matt 8:21; Luke $9: 59) . .^{2}$

Post-Burial Activities

The New Testament puts emphasis on the hope of resurrection after death. This is in line with Christ's

${ }^{1}$ Ibid., 557.

${ }^{2}$ Byron McCane, "Jews, Christians, and Burial in Roman Palestine" (Ph.D. dissertation, Duke University, 1992), 52. 
concept of death. He referred to Jairus's daughter who was dead as just sleeping (Matt 9:24; Mark 5:39). Lazarus was dead for four days, but when Jesus talked to His disciples about his condition, He told them that Lazarus was sleeping (John 11:11-14).

When Jesus rose from the dead the Gospel of Matthew records that some saints who had "slept" were raised; this was talking of the dead being brought back to life (Matt 27:52). When Stephen was stoned to death, Scripture mentions that he fell asleep (Acts $7: 60$ ).

In the hope of resurrection, Peter and Paul, focusing on what is to happen to the dead saints, do not hesitate to point out that those who will come to life at the resurrection will be awakened from their sleep (2 Pet $3: 4 ; 1$ Thess $4: 13-17 ; 1$ Cor $15: 51-52)$.

As pointed out earlier, in death, as in sleep, the dead are not conscious, they have no remembrance of whatever they did in life, and there is no activity in death. Their emotions are passive, they worship not. Their only hope is waking up in the resurrection. The dead being unconscious during death is well established when after the raising of 
Lazarus from the dead, people expecting to hear about what it is like on the "other side," were not told anything." The only remote reference to post-burial activities is in answer to Sadducees who were trying to trap Jesus. Sadducees did not believe in the resurrection (Mark 12:1827). The levirate was a provision by God to care for the widows and their children. In answer to these conspirators, Jesus did not undo the cultural practice of the levirate. He instead focused on the life to come. In the new life, both marriage and the levirate will be unnecessary (Mark 12:25). Jesus re-emphasized the practice of caring for the widows by asking John to care for His mother in His absence (John $19: 26-27$ ).

When decomposition was fully accomplished and the bones were loose, bones were to be moved from one area in the family tomb to another; "formal rituals of mourning ended, after this secondary burial, approximately one year after death and primary burial."2 This secondary burial was not a public funeral but a quiet family ceremony. Two

\footnotetext{
${ }^{1}$ White, The Desire of Ages, 536.

${ }^{2}$ McCane, 70 .
} 
beliefs accompanied this secondary burial: (1) preserving the person for resurrection; and (2) purifying the deceased from sin. ${ }^{1}$ When one follower of Jesus asked for more time to bury his father before he could follow Jesus (Matt 8:21; Luke 9:59), Jesus' response to let the dead bury their own dead indicates his disapproval of this cultural practice. As long as the bones are in the grave there is no need of moving them from one area to another. In whatever compartment of the grave they may be found, the bones can rebury themselves by staying where they are, until they completely change to earth. White adds that Christ was emphasizing a point that temporal things should not divert a called minister from soul-winning. ${ }^{2}$

\section{Word Analysis}

Greek words pneuma and psuche have been translated "spirit" and "soul" respectively. Many have understood these words to carry an idea of existence even after a person is dead. This segment of the study looks at the

Ibid., 73

${ }^{2}$ Ellen G. White, Testimonies to the Church, vol. 2 (Boise, ID: Pacific Press, 1948), 541. 
meanings of these words in their original languages to determine if there is justification for continued existence of spirits of the dead or souls.

Soul

The New Testament uses the word psuche for soul. This word is found 104 times and has several meanings. One English-Greek lexicon defines psuche as a principle of Iife, ${ }^{1}$ the vital force that animates the body. The word psuche in the New Testament is indebted for its meaning to the old Testament word nephesh and means (1) the vital principle common to all living things (Mark. 3:4), (2) the seat of thought and emotion (Matt 22:27), and (3) a man's real self, ${ }^{2}$ being the whole person. ${ }^{3}$ In other words, it is the seat of life or life itself. ${ }^{4}$

Psuche, soul, as found in the New Testament is not immortal, but it is subject to death. Jesus asked whether

${ }^{1}$ Henry George Liddell and Robert Scott, A GreekEnglish Lexicon (1973), s.v. "Psuche."

${ }^{2}$ David Hill, The New Century Bible Commentary (Grand Rapids: Eerdmans, 1981), 193.

${ }^{3}$ Theological Dictionary of the New Testament (1985), s.v. "Psuche."

${ }^{4}$ Brown, BDBG， 682 . 
it is better to save psuche or kill it (Mark 3:4). This indicates psuche can die. In Mark 10:39, psuche is translated "life." Life and soul are used interchangeably, revealing that soul which is life can be lost (Matt 16:26). Jesus, in counsel to His followers, told them not to be anxious about life, where the word psuche appears (Mark 6:25). Life referred to here is our present mortal life. Eternal life uses the word zoe (John 12:25).

Just like nephesh in the Old Testament, psuche in the New Testament is used for both human and animal life (Rev 16:3). It is translated in a variety of uses, as people (Acts 7:14; 27:37; Rom 13:1; 1 Pet 3:20), emotions (Mark 14:34; Luke 2:35), mind (Acts 14:2; Phil 1:27), and heart (Eph 6:6). In all its appearances, it is never a part of a human being able to live beyond death. Instead, the body and soul exist together forming an indivisible union.

The study of psuche leads us to only one conclusion: that is, the English usage of the word "soul," to mean a force that leaves man after death, is not compatible with the primary use of the word in its original language. Now we turn to the next word in the New Testament, pneuma. Does the use of the word "spirit" in the New 
Testament connote a life within man that comes out and escapes imprisonment of the body?

\section{Spirit}

The word pneuma is used 406 times in the New

Testament. It has various meanings. In key passages it comes as "wind," "Iife principle," "attitude" or "state of mind." Each appearance has to be examined within its context to determine the meaning.

Pneuma comes from the root pneu, which means to blow or to breathe. ${ }^{1}$ This root denoted vital force acting as a stream of air. Pneuma is a very important word in the New Testament. Its root pneu, with a suffix ma, denotes "air set in motion considered as special substance and with an underlying stress on its inherent power." 2 In some passages it is translated as mood (Rom $8: 15 ; 1$ Cor 4:21; 2 Tim 1:7). As a life principle or the power of God that energizes humanity, pneuma is yielded to the Lord at death. Pneuma was yielded at the death of Christ and Stephen (Luke 23:46; Acts 7:59). It is also used as the spirit of God ( 1 Cor

${ }^{1}$ TDNT, s.v. "Pneuma."

${ }^{2}$ Brown, BDBG, 689 . 
2:11, 14; Eph 4:30; Heb 2:4; 1 Pet 1:21) Sometimes soul and spirit are used interchangeably (Luke 1:46-47).

As the life principle, pneuma, spirit, is bound to the body in life. At death, it escapes in the last breath and returns to God. It does not escape and return to God as an entity that can survive on its own. In its many usages as wind, power, wisdom, and others, it does not portray any idea of a self-conscious entity. Life principle is the power of God that only God can impart and withhold.

\section{Textual Analysis}

Matt $22: 32$

"I am the God of Abraham, the God of Isaac, and the god of Jacob. He is not the god of the dead but of the living."

This text has been selected for analysis because it appears to support the idea that the dead are still living somewhere. Since the patriarchs mentioned are all dead, can this verse be taken to mean that dead people become ancestors, alive in some place? Can this justify an idea that spirits of the dead are around us, and as such have a part in the affairs of our daily lives? Does this verse 
support ancestral worship or fear thereof? Did Jesus condemn the levirate marriages instituted by Moses in the Old Testament?

\section{Context}

The context of the verse is resurrection. Sadducees, who did not believe in the possibility of the resurrection (Matt 22:23), were trying to trap Jesus. The only case they could find for their argument was a levirate marriage situation.

\section{Discussion}

The background to the Sadducees' question is in the levirate marriage law commanded by Moses (Deut 25:5-6). Marriage was involved in the levirate--it was not mere sex. There, levirate marriage was not an act of cleansing. When Jesus responded to the question of marriage, he did not forbid the levirate system.

The second part of Jesus' response was in regard to the resurrection. He first turns to the scripture and the power of God. The Sadducees, who believed in the first five books of Moses as the only part of the Bible worth following, did not even know it. They had concentrated on 
the affairs of the world and so had no concern for life after death. ${ }^{1}$

Jesus quotes Exod 3:6. Abraham, Isaac, and Jacob died with a hope of the resurrection. God is not the God of the dead, because those who die in the faith, rest with the assurance of being raised from the dead. God had made a covenant wich each of these patriarchs, which they faithfully kept. They all, like Abraham, looked for a better world (Heb 11:19). They trusted and hoped in the resurrection, after which they would see a better world (Heb $11: 8-10)$. Richard Gardner remarks that Jesus' argument is that "those whom God calls, he maintains in an unbroken covenant relationship that death cannot destroy, and that resurrection will fully renew."2

The Sadducees believed that when one died, that was the end. ${ }^{3}$ But the listing of these patriarchs is an

${ }^{1}$ N. T. Wright, The New Testament and the People of God, vol. 1 (Minneapolis: Fortress, 1992), 212.

${ }^{2}$ Elmer A. Marteus and Howard H. Charles, eds., Matthew: Believers' Church Bible commentary (Scottdale, PA: Herald, 1991), 328.

${ }^{3}$ Douglas Hare, Interpretation: Matthew (Louisville, KY: Knox, 1993), 256. 
argument designed to shift attention away from human solutions to the power of God and His ability to intervene in human affairs and bring divine solutions. ${ }^{1}$ God is able to call into existence the things that did not exist. ${ }^{2}$ Had the Sadducees known their own Scripture and the power of God, they would have come to learn that not only is it possible for God to raise the dead, but He is also able to make life radically different after resurrection. ${ }^{3}$

The text under consideration emphasizes the fact that Exod $3: 6$ is proof from the Torah that the righteous dead will rise. It also confirms the idea that death is but a short sleep. Those who are in the sleep of death count not time by years. They have no knowledge of the passage of time. As Christ comes to resurrect them, it will be like they had just blinked and all things have changed in a moment, in a twinkling of an eye. In this way, God is not the God of the dead, but of the Iiving.

${ }^{1}$ Robert Smith, Augsburg Commentary on the New Testament: Matthew (Minneapolis: Augsburg, 1989), 264.

${ }^{2}$ Biare, 441 .

${ }^{3}$ Paul S. Minear, Matthew: The Teacher's Gospel (New York: Pilgrim Press, 1982), 115. 
The text under consideration does not address ancestral worship; it does not justify the idea that spirits of the dead are around the dwelling places of people. On the contrary, it confirms the idea that, when people die, they wait for the resurrection in a state of nothingness. It also supports, by implication, that widows ought to be cared for after the death of their husbands.

\section{Summary}

Death was viewed in both the old and New Testaments as a historical event marking the end of a person's existence. Israel as a nation was to accept this reality as God's design and to forbid activities that were concerned with the dead and out of harmony with God's design.

Cultures surrounding Israel believed that the dead continued living outside the body. Israel in idolatry practiced foreign rituals that supported the idea of an immortal soul. Both the old and the New Testaments show that there is no support for man, after death, to become a disembodied, immaterial spirit. Death in Scripture is shown as real. The Hebrews never saw it as beautiful. A dying 
person was seen as going into the land of no return, a land of gloom, darkness, and chaos (Job 10:21-22).

Hebrew and Greek words for soul and spirit also leads us to an understanding that neither of these words in both their original language usages entertains an idea of the immortality of the soul or spirit, as a separate entity, from the body.

Textual considerations confirm the truth that the Bible refers to death as sleep. As sleep presupposes a waking up, so does death presuppose a resurrection.

In the Bible, Hebrew funeral practices are not fully described. Isolated texts in various places give glimpses of funeral practices. These isolated texts must be collected and arranged in an effort to produce an outline of rituals. The New Testament is a carryover of many old Testament practices, with an emphasis on the future resurrection. Life after death is demonstrated by the resurrection of Jesus. His resurrection was a clue to what humanity ought to expect after death (1 Cor 15:22). Just as Jesus rose, taking up His body with flesh, bones, and everything pertaining to human nature, so shall it be when believers shall rise at the last day. This does not support 
the idea of an imprisoned soul in the body that becomes freed at death.

This chapter concludes that funeral customs of the Hebrews were a mixture of what God did not condemn and what He forbade--which Israel may have adopted from the heathen nations around.

Chapter 4 compares the funeral practices in Zambia and funeral practices in the scriptures. It points out differences and similarities. It states the zambian practices that can be accepted and continue to be practiced according the culture. These rituals do not conflict with biblical principles. The chapter also brings out practices that can be termed un-Christian, that should not be practiced by Adventist Christians in Zambia. 
CHAPTER 4

\section{ANALYSIS OF TRADITIONAL VIEWS IN THE \\ LIGHT OF THE BIBLE}

The task of this research is to understand pagan funeral rituals and replace them with Bible-based Christian practices. Now that both cultural and biblical practices have been studied and understood; the task of this chapter is to compare the differences and similarities of the practices. It brings out cultural practices that do not conflict with biblical principles, and unveils practices that conflict with the Bible.

There are other cultural practices that the Bible does not address. In such cases, an effort is undertaken to determine principles behind such activities. These principles contribute to determining whether the practices in question can be accepted or discouraged.

The principle of selecting what is worth retaining in customary matters, and what is not, was ratified at the Jerusalem council. At this council, believers discussed and 
decided on what to do with the uncircumcised Gentile converts. Ellen white points out that "the Gentile converts, however, were to give up the customs that were inconsistent with the principles of Christianity."1 They were urged to keep the commandments and lead holy lives by not eating food offered to idols, abstaining from fornication, unclean meats, strangled meats, and from eating blood (Acts 15:29). By implication, what was left out on this list was apparently allowed and hence retained.

In dealing with the Jews in Rome, Paul "did not find fault with their observance of forms and ceremonies, "2 but showed that they were not supposed to reject Christ who was the antitype of all that system. It seems to indicate that there is nothing wrong with rituals if they point to God and promote religious morality in keeping with God's word.

Rites and ceremonies have value only as they fulfill the task of pointing sinful men to righteousness, "elevate the thoughts and ennoble life." ${ }^{3}$ It is in this way that the

${ }^{1}$ Ellen G. White, The Acts of the Apostles (Boise, ID: Pacific Press, 1989), 195.

${ }^{2}$ Ibid., 451 .

${ }^{3}$ White, The Desire of Ages, 310. 
rites required in the service of God differed from the unChristian rituals.

There are, in the Zambian cultural practices, funeral customs that can help Christians grow in their worship of God and Christian experience. This is what Zambian Christianity means: to accommodate some of the traditional cultural practices that are helpful to Christian growth and community harmony. All that are good in Zambian practices are not against God's commandments. This chapter finds principles behind every cultural action and marries them to biblical principles.

This chapter is divided into three major sections. In all three sections, similarities and differences between cultural and biblical funeral practices are drawn. The first section deals with pre-burial activities. The second section analyzes burial rituals. The third focuses on postburial practices.

\section{Pre-Burial Activities}

\section{Similarities}

In both the Zambian traditional practices and the biblical way, soon after death, a close relative is present 
to close the eyes of the deceased. In both cases, either the eldest son or eldest relative closes the eyes of the person (Gen 46:4). This action seems to be a universal one. Not only do people dislike seeing the dead lying with eyes open, this is in agreement with the biblical concept of death as sleep (Matt 27:52; 1 Thess 4:13-17; Job 7:21; 14:10-12). As in sleep, eyes close; so it is with death. A loud shrill of wailing announces the death of a person. This weeping and wailing is common in both the Hebrew and Zambian cultures (Jer 9:17-18). Weeping provides for the emotional need of the moment. Repression of grief is not encouraged in either the Bible or the Zambian culture. Metcalf and Huntington put it even better: "Noise production is a cultural feature, yet its use in funerals achieves the same kind of universality as the emotion of grief."1 It is a cultural requirement for all female mourners to weep and wail. People would wail upon arrival at the funeral house, and at burial. This "weeping is a

${ }^{1}$ Peter Metcalf and Richard Huntington, Celebrations of Death: The Anthropology of Mortuary Ritual (Cambridge: Cambridge University Press, 1991), 68. 
symbol not only of sorrow but of social ties." I " "affirms the existence of a social bond between two or more persons."2 Ellen White says, "There is no sin in weeping."3 Paul, speaking on grief, counsels believers to grieve with a hope of resurrection (1 Thess 4:13). He seems to imply that people without hope were weeping and grieving in a manner that may not have been healthy. Christian grief allows for weeping, yet it leaves room for the hope of resurrection. Hebrews were forbidden to grieve too much. ${ }^{4}$ A Hebrew who learns about a close relative's death would immediately tear the garment and put on sackcloth (Gen 37:34). For Hebrews, this was a symbol of grief. Zambians may not tear their own garments but women tie a black piece of material around their head; for men, it is around the arm, or they sew a piece on their shirt. ${ }^{5}$ In both the

Ibid., 47 .

${ }^{2}$ Ibid. , 45 .

${ }^{3}$ Ellen G. White to Sr. Peck, 21 November 1898, Letter 103, 1898, Ellen G White Research Center, Andrews University, Berrien Springs, MI.

${ }^{4}$ Jack Riemer, ed., Jewish Reflections on Death (New York: Schocken, 1974), 23.

${ }^{5}$ Kaoma, interview, 1995. 
Zambian setting and the Bible, there is a change in garments worn during the funeral. As in other cultures, wearing mourning clothes symbolized mourning and "facilitated the identification of recently bereaved people and thereby elicited appropriately supportive behavior from the wider community." 1

As a cultural response to death, members of the community attend a funeral without invitation. This attendance without invitation is social support provided to the bereaved. As people gather, they extend sympathy and empathy, recognition of loss, and communicate care and support to bring comfort and ease to the bereaved. ${ }^{2}$ This is done through material provision, joining in singing and praise of the departed. The Bible reveals that Hebrews also sang songs of praise for the deceased at their funeral gatherings (Mark 5:38; 1 Kgs 13:30; Jer 9:20-22).

Preparation for burial in both Zambian culture and the Bible involve the washing of the body, anointing it with

Jane Littlewood, Aspects of Grief: Bereavement in Adult Life (London: Tavistock, 1992), 31.

${ }^{2}$ Therese A. Rando, Grief, Dying and Death: Clinical Intervention for Care Givers (Champaign, IL: Research, 1984), 174 . 
oil, and wrapping it in some linen cloth (Mark 16:1). Only after this can burial take place.

\section{Differences}

Rending of cloth is done in the Bible but does not happen in zambia. It has been pointed out earlier that tearing of cloth signifies a broken heart within. Nothing is done in the Zambian culture to be equated with cloth rending.

The second difference is in beating drums. In the Scripture there is no mention of drums being played at a funeral. In the Zambian cultures, drums are played for summoning people in other nearby villages for a funeral; drums are played during funeral dances as people express the virility and courage of the deceased. There is another, more important reason: like in other African tribes, drums and dances are intended to drive away evil spirits. ${ }^{1}$ It appears that drums can still be played for various reasons and functions. The playing of drums becomes questionable when it is used to drive away spirits of the dead. This contradicts the biblical revelation concerning the state of

${ }^{1}$ Metcalf and Huntington, 55. 
the dead.

The biblical understanding reveals that the dead know not what happens on earth and have no influence over the living; a Christian would do well to heed to the scripture. This brings redemption from fear of spirits. It is true, however, that demonic powers affect human beings. For the Christian, the victory of Christ on the cross has brought victory over all demonic forces.

\section{Burial Activities}

\section{Similarities}

Both the Bible and Zambian cultures bury their dead within the same day of death. While the Hebrews had a theological reason for this, most Zambians do it to avoid body decomposition and stench. The family burial ground or family tomb was as important to a Jew as head direction was to a Zambian. In the Tonga tradition, most people who die away from their home areas are transported to their home villages. The Tongas do this because of the belief that the dead have power to make rain in their home areas.

$$
\text { Other tribes take it that the head pointing a }
$$

certain direction would make the dead to rest in their 
graves. If the head pointed a wrong direction, the spirit of the dead would rise to torment the living. Burial within the perimeters of the house or the home of origin, and the head pointing toward the direction of the clan's origin, ensures perpetual claim to the land, and empowers spirits to bring rain. The Bible however does not support the idea that the spirits contribute to the fertility of the land and the making of rain. Therefore, biblically, it does not seem to matter which direction the head points. Christians can bury with the head pointing in any direction as long as there is no fear of a haunting spirit coming back. Christianity believes that all believers will rise at the coming of Christ regardless of burial position or direction. Another similar belief is burial in the ground without cremation. In agreement with Gen $3: 19$ and Deut 21:23, the Zambians look at cremation with abhorrence. Burying in the ground is the only practice traditionally accepted.

The ritual of shaving hair off sometimes comes shortly after burial. In the eastern part of the country, the Ngoni and their related tribes shave their heads at funerals of close relatives. This is similar to what the 
patriarch Job did at the funeral of his children (Job $1: 20$ ) as a sign of mourning. In Zambia, it is an expression of losing a part of one's self.

One more comparable cultural expression is the mourning meal. The Israelites did not eat the mourning meal at the grave, they ate the meal at home (2 sam 3:35; Jer $16: 7)$ because the meal was to comfort the mourners. ${ }^{1}$ Zambians also eat their mourning meal at the funeral house. Providing food for the bereaved and the mourners is in line with the gospel culture of caring for the needy (Matt $10: 42)$.

During the intense period of mourning, bathing and wearing clean clothes are not done. Like in many other cultures, the chief mourner does not groom himself. The use of soap, oil, and shoes are discouraged. Parry observes that "throughout the mourning, he must wear a single garment, sleep on the ground and avoid 'hot' food."2 This marks the difference between one who is sorrowing and one who is

${ }^{1}$ Fieldman, 83.

"Jonathan Parry, "Sacrificial Death and the Necrophagous Ascetic," in Death and the Regeneration of Life (Cambridge, London: Cambridge University Press, 1982), 85. 
happy.

\section{Funeral Fire}

Both in the Bible and Zambia, fire is mentioned at funerals. Funeral fires come in many forms; fire is lit at the funeral home to provide warmth and light to the mourners who sleep outside the house as long as burial is yet to be done, and shortly after. The size of the fire depends on the number of people attending the funeral, which is commensurate with the honor vested upon the deceased. The fires mentioned in the Bible, in honor of king Asa, are not condemned by God or His prophets. These fires and the activities associated with them do not contradict the normative faith of the scriptures.

This section concludes that if the practices are similar in being condemned they need to be discarded. If however their similarities are positive, then they are promoted.

\section{Differences}

Villages in Zambia make an issue of burying a person in a grave dug the day before. The Bible, however, does not mention covering up the grave dug previously. In fact, 
sepulchers were hewn out of rocks several years before. Caves in which some were buried were always open and ready to receive the dead. The Bible seems to take a position that the grave is never affected by the passage of time before burial. No enchanter or medium can use the grave for anything. The dead, who sleep, have no knowledge of the time when the grave was dug.

In addition to this, the Bible has resurrection at the end of everything. Zambian cultures have no resurrection in their traditional belief about the dead. They instead see a continuation of life in a different form: to serve the living with furthering their mortal life. ${ }^{1}$ While the ancestors are to be remembered until their resurrection, the Zambian ancestors have a continuous existence among their own; there is no bodily resurrection in this culture.

Many tribes in Zambia offer some gifts to the dead at the funeral. Many of these gifts are placed in the grave and buried together with the dead. Some items are placed on

${ }^{1}$ Victor C. Uchendu, "Ancestrocide! Are African Ancestors Dead?" in Ancestors, ed. William H. Newel (Chicago: Mouton, 1976), 291. 
top of the grave. The Bible has only grave markers placed on top of the grave. Sometimes trees are planted there for identity. Some of the items placed on top of the grave in the Zambian situation are there for identity purposes, but many are placed there for use by the dead. Since the Bible is clear on the matter concerning the state of the dead-that they have no dealings with what happens under the sun-placing items on the grave is a mere waste of things that could benefit the living. The Bible principle of not being wasteful (John $6: 12$ ) should be considered seriously. It would be much better to encourage people to give gifts to one another while living, because, as the Bible reveals, the dead having no knowledge of what happens on the land, and certainly do not appreciate gifts given while in the grave. The Tonga, kuzemba, running or walking on top of the grave, has no support of the scriptures nor a positive equivalent for it. This cultural practice is difficult to understand. It seems to stand in contradiction with honoring the ancestors. The Bible respects the burial places of people. While no worship at such places is indicated, desecration of these areas is unheard of either. In life, people do not jump over or step on people while 
they sleep. If this were to happen, it would be taken as utter disrespect of the one sleeping. In the same way, walking or jumping over the grave of the dead does not show respect to the deceased or the bereaved.

\section{Post-Burial Activities}

\section{Similarities}

The mourning period for most Zambian cultures and what the Bible reveals is basically the same. The first seven days are most often regarded as the funeral time; this is the intense period. After which, thirty days constitute the second phase. The last phase continues for a year. Hebrews have the same time frame for mourning. Without much elaboration, God gave a law that man should never touch a dead person. If one does so, one becomes unclean for seven days (Num 19). When Jesus came, He lived differently and touched even the dead (Luke 7:1115). Jesus touched the dead without considering Himself unclean for seven days; He did not see the need of going to wash in the river. By this He demonstrated that true religion is not of rules and regulations, but a heart of service in love and dedication to alleviate humanity's 
misery and woe.

The many cleansing rituals that involve washing in treated or plain water ought to be looked at in the light of the gospel and the life of Christ. It is a healthful thing to wash after touching any foreign item, to prevent crosscontamination. If, however, washing is for the removal of a spirit, such cleansing rituals must fall into disuse.

One important activity noted earlier is the levirate marriages. As Lewis puts it, "True levirate enables the dead man's widow to be taken over by his surviving brother (or cousin) so that the survivor can give her children in the name of the deceased."1 The Bible seems to focus on giving children to the woman who could not have children with the deceased husband. The Bible does not, however, speak of abandonment of the woman after children have been born. It seems to support the idea of marriage.

The children to be born from the levirate were to support the mother. In the African situation, marriage was considered, whether there were children or not. The

${ }^{1} I . M$. Lewis, Social Anthropology in Perspective: The Relevance of Social Anthropology (London: Cambridge University Press, 1985), 136. 
Africans need children not only to care for their widowed mother but to have children who can venerate them so that they can fully become ancestors ${ }^{1}$ and continue the lineage. ${ }^{2}$ Booth points out that at times the dead may choose to come through the new-born child; this child bears the name of the deceased, thereby forming a link between the dead and the living. ${ }^{3}$ Dying childless in the Lozi culture was considered bad luck; the dead was buried with a piece of charcoal between the buttocks to go with bad luck. ${ }^{4}$ When Jesus was asked a question that implied the levirate (Matt 22:23-28), His response to the Sadducees did not condemn or disallow the levirate in this life. The principle of caring for widows and childless women was underscored when Christ on the cross gave His mother to John to care for (John 19:2627). Done properly, the levirate system in the African culture contributes to the beauty of the gospel. Cultural

${ }^{1}$ Ibid. , 135.

${ }^{2 A}$. Shorter, "Conflicting Attitudes to Ancestor Veneration in Africa," AFER 11, no. 1 (1969): 29.

${ }^{3}$ Newell S. Booth, Jr., "Time and Change in African Traditional Thought," Journal of Religion in Africa 7, no. 2 (1975): 87.

${ }^{4}$ Imasiku, interview, 1995. 
relativity in this case does not undermine biblical authority. ${ }^{1}$

\section{Differences}

One very notable cultural issue that stands out against the word of God is the ritual sex for cleansing the bereaved. The Bible's command is clear (Exod 20:I4); adultery or fornication is strictly prohibited. Since the issue in this discussion is fear of spirits that rise from the dead, a proper understanding of two important theological facts clarifies and settles the matter.

First, the Bible sees spirits not as the dead coming up from the dead, but demons masquerading as dead relatives (1 Sam 28:11-16). White clearly reveals that the devil has power to let evil spirits appear purporting to be dead relatives or friends. ${ }^{2}$

Second, the Bible presents the dead as sleeping, unconscious, and unaware of their surroundings (Eccl 9:5-6).

${ }^{1}$ Stephen A. Grunlan and Marvin K. Mayers, Cultural Anthropology: A Christian Perspective (Grand Rapids: Zondervan, 1988), 253.

${ }^{2}$ Ellen G. White, Early Writings (Washington, DC: Review and Herald, 1945), 262. 
The only time the dead will be alive is at the resurrection (John $5: 29$ ).

Once these two facts are understood, then Christians ought to believe in the power available to combat evil demonic forces (Luke 10:17-18; Matt 10:1). Power both to proclaim the gospel and defeat spirits is in one package, given to Christian believers before Christ ascended to heaven (Matt $28: 18-20$ ). ${ }^{1}$

Therefore the sin of ritual sex, regardless of its being cultural and deep-seated, has to be weighed by biblical standards. Since all Christians are to be judged by the law, there should be no compromise of any kind.

Another dehumanizing practice is letting the bereaved crawl on both hands and knees, either towards the funeral house, as in the Bemba-Ushi culture, or around the house in the Ngoni practice. This practice does not seem to have an explantion as to its meaning in the whole funeral ritual. It seems only to serve the purpose of punishing the bereaved. The Bible seems to be more sympathetic to the

${ }^{1}$ Carolyn Butler, "To Turn Them from the Power of Satan to God," in The Gospel Unlimited (Pasadena, CA: William Carrey, 1994), 199. 
bereaved and provides comfort, not punishment. God specifically commanded never to take advantage of a widow (Exod 22:22); God Himself takes the responsibility of defending the widow and the fatherless (Deut 10:18). As the New Testament church was growing, care for the widows was one of its top priorities (Acts $6: 1$ ). James even defines true religion as one that takes care of widows (Jas 1:27). To let widows and widowers be subjected to dehumanizing experiences, while the church watches in silence, is a denial of the faith of our fathers.

The biblical principles above apply in the situation when property of the family is being taken by unfriendly relatives, leaving the widow penniless and in despair. In the Hebrew economy, the levirate marriage took care of the bereaved woman. All children of the deceased were covered in receiving the inheritance; none were left in despair (Deut 29:9; Num 27:5-11). This culture of depriving the wife and children of property they struggled to acquire together with the deceased must be addressed in the light of both Old Testament principles and the Christian gospel. 


\section{Strictly Forbidden Practices}

Some practices are detestable to the Lord. The Lord counseled the children of Israel not to imitate the detestable ways of the Canaanites (Exod 34:11-16). By implication, some ways were not detestable. The Lord specified some of the detestable ways. When Jews went into Babylonian captivity, "many of the people had received heathen ideas, and customs. . . In many things they conformed to the practices of idolaters." 1 These practices they brought with them and practiced in their communities. During mourning, Israel was not allowed to cut and mutilate themselves for the dead (Deut 14:1-2; Lev 19:27-28). Such behavior was against God's holiness. This might have been so because the heathen cultures might have been practicing such ways, as implied in the Mt. Carmel episode ( $1 \mathrm{Kgs}$ $18: 28)$

In some African funerals, the bereaved torture themselves by throwing their bodies to the ground, hitting their heads against hard objects. In some cases, they badly hurt themselves. Such mourning practices were discouraged

${ }^{1}$ White, The Desire of Ages, 29. 
by Paul ( 1 Thess $4: 13$ ) because they evidenced a lack of hope and faith in the power of God to bring resurrection to those who die. Ellen white points out:

We are not like the heathen, to have days and nights of mourning when nothing is heard but dismal chanting for the dead, for the purpose of arousing human sympathy. We are not to clothe ourselves with a mournful countenance, as though our friends and relatives were forever parted from us. ${ }^{1}$

Ellen White raises another point supporting Paul in regard to Christian funerals. She calls a customary mourning without restraint, which involves more sorrow and distress, as an evil she was determined to shun. ${ }^{2}$ It is sin, she says, "to indulge without restraint, in mourning and lamentation." ${ }^{3}$ Christians, therefore, ought to be examples in practicing funeral rituals that do not contradict the Bible faith.

One common practice among many Zambian traditionalists is the consultation of diviners to explain

${ }^{1}$ Ellen G. White to Friends on Pitciarn Island, I January 1894, Letter 65a, 1894, Ellen G. White Research Center, Andrews University, Berrien Springs, MI.

${ }^{2}$ Ibid.

${ }^{3}$ Ellen G. White, "Cheerfulness in Affliction, " Review and Herald, November 1, 1881, 273. 
the cause of death and possibly punish the suspected witch. The scripture forbids divination and medium consultation (Deut $18: 10)$

The Tonga have basangu, which are true mediums. These choose certain people through whom they "bring messages from the spirits of dead to the world of the living.". The messages they bring are usually complaints about the neglect of certain old customs or breaking of some taboos. ${ }^{2}$

The Bible uncovers that the Devil and his angels have power to speak through mediums (Gen 3:1-4). The Lord, knowing that the Devil would continue to use this trick throughout history, forbade the consultation of mediums (Exod 22:18). In line with God's directives, King Saul expelled all mediums and spiritists in Israel (1 Sam 28:3). After his fall and in desperation, Saul, against God's command which he knew very well, consulted the witch of Endor with disastrous results (1 Chr 10:13-14).

The consultation of spirits is in direct opposition

${ }^{1}$ Wendland, 45 .

${ }^{2}$ Ibid 
to the belief in God's Spirit (John 14:15-18; 15:26; 16:13) and an expression of lack of faith in God and His promises (John 14:14). Since God has promised to give His people whatever they ask for through the prayer of faith, consulting dead spirits is despising God, and perpetuates the pagan idea of the survival of the soul after death. Another forbidden practice is offering food to the dead and eating the Lord's tithe during funeral time (Deut $26: 14)$. It is a common practice among many tribes in zambia to slaughter a lot of cattle for the funeral at burial and several months later at a memorial service. ${ }^{2}$ Both these occasions carry with them an idea of pleasing the dead. The Bible forbids the practice of offering food to the dead because it is wasteful. The dead cannot eat the food given to them. It is a better choice to let the people eat the food. The provision of food at a funeral for people to eat should not be confused with offering food to the dead. In offering food to the dead, no human being living is allowed to eat any of it; while the food eaten at a funeral is for

IIbid. $8 \dot{8}$.

${ }^{2}$ Ibid. 
the nourishment of the mourners. The tithe is sacred, it is for the Lord. A terrible calamity such as death cannot be used to divert the tithe from the purpose it was intended (Mal 3:6-11), as important and urgent the funeral may be.

\section{Ancestral and other spirits}

In chapter 2 beliefs of the four Zambian tribes in focus were discussed. Common in all of them is the belief in spirits. Various names have been given to different spirits, according to their activities and influence on human beings. It is important to note that spirits are placated, whether they are ancestral or not. This section of study evaluates ancestral and other spirits in the light of what the Bible says.

Ancestors are respected men or women of society who, after they die, attain a higher status as they leave their visible bodily forms. These dead are respected and remembered because of their deeds that hold special places in the lives of the living. ${ }^{1}$ At death the individual becomes idealized, his faults are disregarded, and he

John A. Kisaka, "The Adventist Church's Position and Response to Socio-cultural Issues in Africa" (D.Min. project dissertation, Andrews University, 1979), 39. 
becomes elevated to a level of high morality. ${ }^{1}$

Ancestral rituals as practiced in Zambia focus on the dead's spirit rather than genealogy. Rituals are there to provide for the needs of the spirits, especially those who died recently, because those who died long ago tend to be forgotten after some generations and do not seem to affect the living after such a long time. ${ }^{2}$ Staples sees ancestors as spirits of the deceased who are members of lineage, ${ }^{3}$ meaning those within the extended family circle. What does the Bible say about these spirits? The term "ancestor" in the Bible is understood in the context of genealogy. Israel, in both the old and New Testament, remembered and respected their predecessors whom they talked about in their homes and religious gatherings. ${ }^{4}$ Jews glorified themselves in being descendants of Abraham (John

${ }^{1}$ Ronald Green, "Religion and Morality in the African Traditional Setting," Journal of Religion in Africa 14, no. 1 (1983): 7 .

${ }^{2}$ Bruce Lincoln, "Two Notes on Modern Rituals," JAAR 45, no. 2 (1977): 152, 153 .

${ }^{3}$ Russell L. Staples, "Christianity and the Cult of the Ancestors: Belief and Ritual among the Bantu-speaking Peoples of Southern Africa" (Ph.D. dissertation, Princeton Theological Seminary, 1982), 476.

${ }^{4} \mathrm{Kisaka,} 39$. 
$8: 33,53)$. "Father" in this context meant forefather or ancestor. ${ }^{1}$ The Jews never worshipped their dead relatives. Kisaka, an African, looks at ancestral veneration in the same way Jews look to Abraham with respect and Christians look to Christ in genealogy. Having been born as a man, He now is our ancestor. We are descendants of Christ. ${ }^{2}$ Shorter, a Catholic priest, looks at ancestors only to mean a deceased relative who in death continues to exercise authority and responsibility in a different way. ${ }^{3}$ The author agrees with Kisaka and adds that any belief that contradicts the scripture in this case, a belief in the dead living, must be discarded and preached against.

Kisaka puts it well: "Ancestor veneration may go to an extreme and place their ancestors in the place of God, thus breaking the law"4--the law of not having other gods before Jehovah. The other problem with ancestral spirits is a

${ }^{1}$ Ibid. , 40 .

${ }^{2}$ Ibid., 41

${ }^{3} \mathrm{~A}$. Shorter, "Ancestor Veneration Revisited," African Ecclesial Review 25, no. 4 (August 1983): 198.

${ }^{4} \mathrm{Kisaka,} 41$. 
belief that the dead return home in nonphysical bodies. ${ }^{1}$ It is important to remember that the Bible preserves the history of people, especially forefathers. Zambians keep the memory of the dead in their minds and through activities known as rituals. If these were only for the purpose of remembering the good deeds of those who lived before and to learn from them lives of service to fellow human being, then ancestral veneration would be a positive way of life.

At certain periods Zambian traditionalists go to the graves of the dead, which are marked by a tree or stones. These trees and rocks are identifying marks of the grave. During such visits, the acts and deeds of these dead are recalled. Christians in this contemporary society have memorial days when the deceased are remembered, not because they live as spirits, but to keep their good works remembered as examples for those living to emulate. African ancestral beliefs have one positive outcome, which is the

${ }^{1}$ Bong Rin Ro, ed., Christian Alternatives to Ancestral Practices (Taiwan: Asia Theological Association, 1985), 22 . 
unifying and solidifying of society. ${ }^{1}$

The Bible teaches that the dead have no existence at all in this world. However, the Bible shows that ghosts exist (Luke 24:37-39). These ghosts are the same fallen angels who in ages past were driven out of heaven after they had rebelled against God together with the Devil (Luke 10:17-18). Jesus on various occasions cast them out of human beings they possessed, and gave power to His followers to do the same (Matt 10:1-2).

From a biblical perspective, ancestral worship can properly refer to religious acts rendered to God as a creator, not to ancestors as spirits. Spirits of the dead people should never be objects of worship. Africans would prefer to use the word veneration, which means honor or respect (Exod 20:12; Deut 5:16), like we respect our earthly parents. Even in the New Testament, respect or honor goes to human parents or elders (Matt 19:19; 1 Tim 5:17; 6:1). In this sense ancestors may be venerated and ought to be rightly so, in the sense, of respect with no attempt to

${ }^{1}$ David A. Mclean and Ted J. Solomon, "Divination among the Bena Lulua," Journal of Religion in Africa 4, no. 1 (1971): 28 . 
manipulate any supernatural powers.

Ancestors are respected as their words, actions, and deeds are remembered for the purpose of inspiring the living towards right living in the community. This way even biblical ancestors were honored by Jews. Christians today read about their lives in the Bible and try to imitate their examples of righteousness. In some Zambian societies, however, ancestral veneration is seen only in terms of the spirits of the dead that come to haunt us and therefore need placating.

\section{Cenclusion}

This chapter concludes that some activities that Zambians practice at funerals are evil and can be termed unchristian. There are, however, other practices that are in total harmony with biblical principles and as such can be accepted in Christianity. The focus in this research is on the practices that are unchristian and what can be done about them. Chapter 5 answers this question, and outlines a possible solution or reaction to these unchristian rituals. 
CHAPTER 5

\section{A CONTEXTUAL, CHRISTIAN RESPONSE}

TO FUNERAL PRACTICES

The previous chapters have helped us understand the Zambian cultural practice of death and its rituals. Issues have surfaced that need attention. The biblical understanding of death and death rituals answered some of the issues raised in the cultural practices. A comparison between cultural funeral practices and biblical funeral practices led to a conclusion that there are some practices that are outright evil and pagan. It also concludes that there are some socio-cultural elements that are good and could contribute positively to Christian life. What method can be effective in selecting the good from the bad?

This chapter presents a method that may prove helpful in confronting pagan practices. It first discusses a one weekend seminar program that is designed to educate both pastors and laity in ethnotheological issues (see 
Appendix E). During this weekend, eight lessons are presented, in which Bible study lessons are included. These are designed to combat eight issues that surfaced from the questionnaires, interviews, and the analysis of traditional beliefs.

Second, a model contextualization process is suggested to confront the pagan rituals and beliefs behind the cultural practices.

\section{Target Audience}

This study relates to all the tribes of Zambia. The main concern is not to directly reach the whole population of the country, but to go through Seventh-day Adventist Christians. I believe that if the Adventist Christians would learn the issues involved and live by what the Bible dictates, their Iifestyle would permeate the communities they live in and as such have a greater impact upon the society.

In Zambia, there are more churches than pastors can handle; therefore, the involvement of lay leaders from the 
local level becomes a necessity. ${ }^{1}$ There are 1,120 churches and companies and a total of 168 pastors to manage these churches. ${ }^{2}$ At an average, one pastor cares for about six churches and companies, which is much more that pastors can effectively manage. Many of these churches are in distant places, that are hard to reach due to transport problems, affecting all people in the rural areas of the country. Because of this problem, it is more convenient and costeffective to have a one-weekend seminar at a central place where representatives from various churches would gather. At first I thought I would need two weekends for the seminar; I have discovered, however, that the lessons that need to be taught can be adequately dealt with on one weekend. Second, lack of finances on the part of the local churches and the long distances members would travel led me to decide on a one-weekend seminar.

\section{Selection of Topics}

The topics for the lessons were selected through

${ }^{1}$ Pardon K. Mwansa, "A Training Program in Pastoral Responsibilities for Church Elders in Lusaka, Zambia" (D.Min. dissertation, Andrews University, 1993), 1.

${ }^{2}$ Ndatoya, interview, January 31, 1996. 
popular demand. There were fifty questionnaires sent to Zambia: twenty-five for pastors and the other twenty-five for the laity to respond to. Out of the twenty-five sent to pastors, fifteen responded, and of the ones sent to the laity, twenty responded, bringing the total number of responses to thirty-five out of fifty. When the responses were examined, the topics that were chosen most often were selected for our lessons.

Four former missionaries to Zambia were interviewed, who felt that the ritual of cleansing stood out as significant in their experience with funeral customs. They also indicated that the teaching on the state of the dead and spiritualism needed a lot of emphasis. ${ }^{1}$

Eight Zambian students studying at Andrews were interviewed. They also agreed that the state of the dead and spiritualism need clarifying in the minds of the local believers.

Having selected the eight lessons that needed attention, the next step was to determine the method of

${ }^{1}$ Donna and Richard Worley, Dorothea Amey, Paul and Lean Eagan, Ken and Shirley Thomas, missionaries to Zambia, interview by author, January 3, 1996. 
teaching that would be employed in the transmission of information to the laity and pastors. The questionnaires received back had an overwhelming response that seminars needed to be organized where these issues would be addressed. Therefore, I chose to organize a seminar in which to educate the people on these ethnotheological issues.

\section{Teaching Method}

It is hoped that all elders of the churches with their pastors will attend these seminars. Only the adults are expected to attend. It has been observed that adults learn differently from children. Cross has observed that adults learn more when they aim at solving a particular problem. ${ }^{1}$ This dissertation has several problems to solve, therefore this method of teaching is fitting. The process of learning chosen is a combination of lectures, on-the-job training, and workshops. These three were chosen because an education testing service survey, conducted by Cross and Valley, showed these three at the top of the list as the

${ }^{1}$ Patricia K. Cross, Adults as Learners (San Francisco: Jossey-Bass, 1981), 189. 
most effective ways of teaching adults. ${ }^{1}$ Dunbar also agrees that on-the-job training is one of the most effective methods of teaching preferred by most adults. ${ }^{2}$

The nature of the seminar requires a sharing of information. Adults feel useful and appreciated if their experience is called into play. ${ }^{3}$ In this seminar their experience is tapped on to draw from their wide and varying experiences. A less formal atmosphere of learning is created and in their smaill groups they actually make decisions and formulate principles that can be used in their local churches. By doing this, the adults learn more-George and Logan discovered that adults learn better in the context of doing. ${ }^{4}$ Not only do they learn more, they also teach a lot as they share information.

\footnotetext{
${ }^{1}$ Patricia K. Cross and John Valley, eds., Planing Non-Traditional Programs (San Francisco: Jossey-Bass, 1974), 30 .
}

${ }^{2}$ Colin Alfred Dunbar, "The Bible Instructor: A Manual for the Training of Lay Bible Instructors" (D.Min. dissertation, Andrews University, 1992), 80.

${ }^{3}$ Malcom Knowles, The Adult Learner: A Neglected Species (Houston: Gulf, 1984), 57.

${ }^{4}$ Carl F. George and Robert E. Logan, Leading and Managing Your Church (Old Tappan, NJ: Fleming H. Revell, 1987), 110 . 


\section{Preliminary organization}

The central place where the meeting is to be held is chosen during the workers' meeting. The workers, being pastors, vote to select the central place and the dates for the meeting. The chosen place is a district with several churches around. The church members in that area are requested to volunteer to host one or two seminar participants as a cost-saving measure on the part of the church. The churches are asked to choose their representatives, preferably a man and a woman.

All the seminar participants are asked to come to the central church where the meetings will be held. All seminar participants are to arrive on Friday before sunset because at sundown all will be gathered at church to start the seminar. As the people arrive, they are taken to their hosts where they will be accommodated.

At sundown every participant arrives at church and receives a name tag and a printed seminar program (see Appendix E) .

\section{Model Contextualization Process}

This part of the study gives a quick overview of 
various approaches used in the process of communicating the gospel to people of different cultures. There are several improper methods of contextualization. These are defined. Finally, a model contextualization process is outlined, which the local churches can use to evaluate all their cultural funeral and non funeral practices in the light of the Scriptures and develop their own Christian practices. The first danger in contextualization is syncretism.

\section{Cultural syncretism}

This is the amalgamation and accommodation of nonChristian practices with Christian practices. Syncretism refuses to break with the traditional practices whether they agree with the Bible or not. It instead mixes all practices and calls them Christian. This is done basically by those with deep respect for other cultures who do not want to let the gospel seem foreign to them. This approach overlooks the fact that sin can be found in the cultural practices of a society. ${ }^{1}$ This mixing of cultures produces a kind of neo-

\footnotetext{
${ }^{1}$ Paul G. Hiebert, Anthropological Insights for Missionaries (Grand Rapids: Baker, 1985), 185.
} 
paganism. ${ }^{1}$ Syncretism tends to accept everything done at funerals in the Zambian culture and mixes them with what Christianity accepts, without removing anything whether sinful or not. One study indicates that the Catholics take this approach. ${ }^{2}$

\section{Cultural Relativism}

Charles Kraft's ethnotheological approach to contextualization has a dynamic understanding of scripture and its authority. ${ }^{3}$ He sees the Bible as an inspired casebook. This approach does not deny the existence of God's absolute truths; it affirms that these absolutes might be realized differently from culture to culture. Kraft would like to see the Bible freed "from the historically conditioned forms in which it is clothed"4 and clothed in forms appropriate to the contemporary culture. The problem

\section{${ }^{1}$ Ibid.}

${ }^{2}$ Zebron M. Ncube, "Ancestral Practices: A Program Designed to Create Faith among Adventists in Zimbabwe" (D.Min. dissertation, 1988), 117.

${ }^{3}$ Charles H. Kraft, Christianity in Culture: A Study in Dynamic Biblical Theologizing in Cross-cultural Perspectives (Maryknoll, NY: Orbis, 1979), 221.

${ }^{4}$ William Larkin, Jr., Culture and Biblical Hermeneutics (Grand Rapids: Baker, 1988), 142. 
with this is that it tends to be selective about what it can accept from scripture, and often rejects what culture does not seem to support. It tends to overlook the original context and ends up losing the original meaning and message. Regarding the Bible as "the word of God only in a potential sense"1 one may tend to inject one's own meaning into it to fit one's culture. Bosch adds that relativism has a danger of creating "mutually exclusive theologies."2

\section{Cultural Rejectionism}

Cultural rejectionism is when everything done in a particular culture is judged evil. In this case, all the rituals practiced at funerals are judged as evil. This can create a lot of problems: first, it strips the local people with everything they know and leaves them with a "cultural vacuum."3 Second, this suppression sends the old ways underground and they are practiced in secret. ${ }^{4}$ This happens

${ }^{1}$ David J. Hesselgrave and Edward Romen, Contextualization (Grand Rapids: Baker, 1992), 61.

${ }^{2}$ David J. Bosch, Transforming Mission (Maryknoll, NY: Orbis, 1993), 427 .

$$
{ }^{3} \text { Hiebert, } 184 \text {. }
$$

${ }^{4}$ Poovelingan R. Solomon, Ashram: A Contextualized Model for Discipling the Hindus of Tamil Nadu (D.Min. 
in situations where not enough teaching was done about the evils of certain practices. Third, it denies the new converts the privilege of making their own decisions about what is evil in their culture.

\section{Other}

In conclusion, Solomon adds distortion of meaning to this list, when Christian symbols are changed to accommodate local practices, cultural captivity, primacy of culture, and accurate translation ${ }^{1}$ as other ways of contextualization that are unsatisfactory.

\section{Critical Contextualization}

In this section I suggest the process of contextualization that the local churches in Zambia can use to critically examine every cultural practice before it can be rejected as evil or accepted as good.

\section{Awareness}

The first step to critical contextualization is for the Church to be aware that there is a problem. The Church

dissertation, 1994), 41-43.

${ }^{1}$ Ibid. 
must recognize that there is a need to do something about a ritual. This awareness may come as Christians face funerals. To be aware of a need involves the participation and guidance of the church leadership. Awareness may come as people meet and interact with others from different cultures. It also comes through the influence of the Holy Spirit upon the human heart. Finally, awareness comes as preachers communicate the gospel, showing how man is "forever making mistakes and committing sins at the level of group life."1 The congregation must be aware about the need for change.

\section{Information}

The second step is to gather as much information about the ritual as possible. This is to find areas that need changing in that ritual. To understand the ritual, the Church must call for specialists in cultural rituals. These should be invited to a Bible study to describe the rituals in detail.

At this stage, there is no evaluation, critiquing,

${ }^{1}$ Haskel M. Miller, A Christian Critique of Culture (New York: Abingdon, 1965), 10. 
or analyzing involved. Here, just the uncritical description occurs of songs, dances, recitations, and other activities. The church needs to make use of the senior members of society to get this information. Once the information is in, then discussion proceeds.

\section{Discussion}

The purpose here is to understand the old ways by defining the meaning and function of each activity. Each described song, dance, or recitation is now dissected for its meaning and function in the whole ritual. At this point, there is still not criticism of the customary beliefs and practices. People are free to openly talk about their traditional practices as they best know and understand them. People understand issues differently, and as the church openly discusses the ritual, people harmonize their understanding of their practices. The best people to reveal the meanings underlying the funeral practices are the older members. It is advisable to invite non-members of the church or experienced anthropologists from the local university to share their knowledge in this area of death rituals. 
4. Education

As the Church reaches this step, it must take the Bible as supracultural and authenticate its validity as absolutely non-negotiable. The Church must first understand that there are aspects of truth in the word that need to be accepted just as they are by any culture. For example, the sacrificial death of Christ being the sole source of salvation must remain this way in all cultures.

Consider that there are activities whose symbols and meanings go together and cannot be separated. The sacrament of baptism with water, for example, has its symbol tied in with the meaning and cannot be separated even in the process of contextualization.

During this step, a Bible study is organized, and texts must be gathered that address the issue in consideration. The local leaders invite all members to gather texts about funeral rituals, the nature of man, the state of the dead, spirits, and spiritualism, depending on the question to be addressed. The minister's expertise is required in this step for proper exegesis of the texts.

This step is crucial: the Church must clearly understand and 
accept what the Bible says in order for contextualization to be effective.

\section{Consultation}

The fourth step is just the beginning of evaluation. Now that the people can see both what culture intends and what the Bible says, to avoid biases, the involvement of Christians from different cultures is recommended.

Sometimes an outsider can see more in the practices of others than the owner does. These outsiders can make the local people aware of what they could not see in their own culture, positively or negatively. Missionaries can offer a lot to the local community at this point in

contextualization. People from other cultures can guide and probe for better clarity and understanding of rituals.

\section{Evaluation}

The congregation goes through the process of critically evaluating their funeral rituals in the light of the biblical understanding of the particular aspects of ritual activities. In this step, both the people and leaders critique the old practices. This helps the local people grow spiritually as they apply biblical teachings to 
their own lives. The missionary can assist even at this point in raising questions that the owners of culture may have glossed over.

\section{Decision}

Once evaluated, the congregation may decide to discard the activities they see as unbiblical and sinful, and keep the ones they perceive as all right. In making these decisions, the congregation might substitute symbols with new symbols borrowed from other cultures. These functional substitutes help fill up the vacuum left by the rejected unchristian symbols. The local believers may decide to add some aspects to their ritual with a foreign activity. For example, the Lord's Supper is an addition to cultural activities, but brings in a new meaning in the newfound faith. The congregation may see a funeral ritual in the Scripture that can be added to their own ritual but with a new Christian meaning.

Believers may decide to "create new symbols and ritual to communicate Christian beliefs in forms that are indigenous to their culture." 1 Whatever decision the local

${ }^{1}$ Hiebert, 189. 
people come up with, as long as it is theologically and culturally sound, the missionary cannot discourage or disallow. The congregation may even modify the old practices to give them explicit Christian meanings.

\section{Implementation}

The final step is arranging the new practice the people have created into a new ritual that expresses Christian meanings of the events. From this point on, the congregation begins to teach these to children, the community, and new converts. Whatever they decide must be put into practice whenever the occasion of a funeral occurs. 
CHAPTER 6

SUMMARY, CONCLUSION, AND RECOMMENDATIONS

\section{Summary}

The task of this study was to develop a program for equipping pastors and laity in Zambia to understand unchristian funeral practices and replace them with acceptable Bible-based Christian practices. This task was undertaken because at funerals many rituals practiced are in direct contradiction to Christian beliefs and practices. Regardless of this, there are some practices that were discouraged at the coming of early missionaries and judged as bad, which are in fact good moral practices. In order to develop this program, a traditional understanding of death and death rituals was studied.

It was discovered that all the funeral practices done in Zambia have a bearing on their beliefs about spirits. Although rituals practiced vary from tribe to tribe, the principles behind these rituals are more similar 
than different. This, it was unveiled, is due to numerous wars between tribes, trade, and early migrations of people that led to mixing of cultures. The basic issue is the fear of the spirits of the dead. All tribes believe that the dead continue their existence as supernatural beings in a ghostlike state. Because of the fear of these spirits, cèrtain practices are done in the traditional society to either appease or drive away spirits.

The study points out some basic practices that are done before burial, at burial, and after burial. Several issues affecting the Church are raised. These issues can be summarized into three classes. The first class have to do with an understanding of the state of the dead. The second class concern an understanding of spirits and spiritualism, and the third class concern the understanding of the morality of cleansing.

The Bible is very clear on the state of the dead. A person does not become a disembodied spirit at death. Death is shown as the end of thoughts, feelings, and activity. It compares death to sleep where there is no motion, cognition, or motivation.

The words "soul" and "spirit" have been misused to 
mean an immortal part of a human being. This study analyzes these words in both their Hebrew and Greek usages and concludes that they have nothing to do with immortality in their many appearances in the Bible. The meaning of immortality seems to have been injected into them later.

Although the Bible does not have a theology of death and death rituals, isolated texts give us a glimpse of funeral practices as they were done in Bible times. None of the rituals in both the Old and New Testaments portray an idea of belief in the survival of the soul or spirit. They all point to a future resurrection and hope in the new life to come.

In comparing Zambian traditional funeral practices and biblical funeral practices, there are notable similarities and differences. The similarities that have no conflict with the normative faith of Bible-based Christians are encouraged. The differences that contradict Israel's faith or are not in support of Christian principles of righteous living are discouraged. A principle surfaces that, in every situation, activities are to be measured against the biblical revelation and, if within the cultural practices are found some practices that are not explicitly 
biblical but are helpful to Christian growth and community harmony, they need to be kept. The process of contextualization was suggested to use when deciding which activities to keep and which ones to discourage or change. The suggested steps to contextualization are: (1) learn everything about the ritual and understand it well, (2) consider the Bible passages that address the same activity, (3) compare the traditional ritual practices with what the Bible says, and (4) decide and formulate a new ritual.

\section{Conclusion}

When Christ ascended, He gave a promise to the disciples and believers concerning His continued presence in the Church. He then sent the Holy spirit to equip every believer with gifts for the propagation of the gospel and Christian growth. This included the understanding and interpretation of God's word. As the Church grew and missionaries were sent to spread the gospel, every newly planted Church was equiped with gifts, even to understand and interpret the scriptures.

Ever since Christian missionaries arrived in Africa, theology has been taught to the native Africans. They were 
told what to believe and what not to believe. They were also told what to retain in their cultural practices and what not to. Believers, however, of every age and culture must be trained to be responsible, and must be equiped to handle their own situations and indeed be trusted with the fact that the ever-presence of the spirit will guide the African Church into making the right decision as to what to retain in their culture and what to discard.

In death rituals practiced in Zambia, the local believers must be involved in the process of deciding the valid cultural practices. The presence and participation of local believers is very important so that they understand the issues, and when the final contextualized ritual is produced, they are able to support it as theirs. This prevents unwanted rituals from going underground, strengthens the spirituality of believers, and allows the Church to propagate itself, manage itself, and finance itself. Contextualization will wean the Zambian Church from Mother West and its cultural baggage that comes mixed with Christianity. Contextualization will assist the African Church in dealing with its own theological and missiological problems. 
In funeral rituals, the local church need not discard everything practiced, because this makes Christianity a foreign religion--which should never be. The local church should not be afraid of keeping good and moral practices that people would identify with. In every decision the Church will make, the Bible should have the final word. It is the degree of allegiance to the word of God that makes the Church strong and spiritual, or weak and irreligious.

This study concludes that the tribes of Zambia believe that when a person dies, he continues to exist in a much stronger and invisible form. The dead are ready to take vengeance upon their enemies unless placated. This belief has resulted into numerous and varying rituals. The Bible, however, shows conclusively that the dead know nothing and have no part in whatever happens under the sun. The dead will only exist when Christ will resurrect all the dead. The appearance of forms of spirits of the dead is the Devil's scheme to perpetuate the lie that the dead do not die. If this lie can be believed, then he would have people gripped with fear and involved in endless rituals. 


\section{Recommendations}

This dissertation has been an eye-opener to me. I have discovered that not much has been written on the subject of death and death rituals in Zambia. This study is not an exhaustive study on the subject, it is just the beginning of what I recommend for Africans to start doing. Much of what has been written on cultural issues in Zambia has been done by people from outside the country. While there is a lot of truth in what they have written, there is a lot of misunderstanding and misinterpretation in their analysis of local practices. This could be minimized if the owners of cultures would write. Therefore the leadership of the Church should encourage people to write on issues that affect the Church in Zambia.

Leaders should encourage the ministerial school to teach and discuss these cultural issues freely.

Campmeeting programs should include Bible discussions centered on some aspects of cultural issues troubling the Christians in their area.

Christian leaders, ministers, or local pastors should have retreats or workers' meetings where cultural issues can be discussed with the aim of finding possible 
solutions to the problems.

Periodic seminars need to be called for to discuss and train Bible workers in areas that affect believers in their traditional beliefs and practices.

This study of funeral rituals should not be limited to funerals, but should be extended to other rituals in the other areas of life such as birth, puberty, and marriage.

To solve the problem of spiritualism, believers must be encouraged in power encounters and exorcism as a public testimony of God's power over the Devil and all demonic forces.

The local church should be encouraged to have functional substitutes for every practice removed, to avoid a vacuum in their members' spiritual or social activity lives.

With proper contextualization, and the willingness of local believers to venture into studying and writing about their local beliefs and practices, the Church in Africa in the twenty-first century will emerge as a force unconquerable for the Master Jesus Christ. 
APPENDIX 
APPENDIX A

LETTER 


\title{
APPENDIX A
}

\section{LETTER}

4875 Highiland Dr.

\author{
Cornelius Matandiko
}

\section{Berrien Springs \\ MI 49103}

Dear Sir/Madam.

My name is Cornelius M Matandiko. a Doctor of Ministry student at Andrews University Theological Seminary. I am involved in a research regarding Zambian traditional activities (rituals) done at funerals. I am looking to you for information vital to this research.

Enclosed is a brief questionnaire. I would apprecate it if you would take the time to fill it out and return it at your earliest convenience.

Thank you for your cooperation.

Cornelius Matandiko. 
APPENDIX B

QUESTIONNAIRE 
QUESTIONNAIRE.

Please Circle One.

1. Tribe:

_Tonga

_Ngoni

-Lozi

-Bemba

-Other

2.Age:

$-15-25$

$-26-35$

$-36-50$

$-51+$

3.Sex:

- Male

_Female

Listed Below are some of the cultural practices done at funerals. Space is provided for any possible additions you may be familiar with. Please indicate which practice is done very often in your culture. Write on the line beside each item. Use the key. 1 = Very often. 2 = Often, $3=$ Sometimes $4=$ Not done.

\section{A. PRE-BURIAL PRACTICES.}

Gun fire.

Piece of material around the head/arm. Dressing in black.

No shave.

_Drum beat.

No burying in a grave dug the day before.

_ Crawling towards the funeral house (Ukulamba)

- (Add your own)

(Add your own)

B. BURIAL ACTIVITIES.

Head toward a certain direction.

Items placed on the grave. 
Mourning songs and dancing.

Relatives throwing soil in the grave.

Walking over the grave(Kuzemba)

- (Add your own)

- (Add your own)

C. POST-BURIAL ACTIVITIES.

Hand washing in ritually treated water.

Family elder's meeting - case review. (Isambo Lyamfwa)

—Cleansing of the surviving spouse(Ukuwamya)(Kusalazya)

Dividing the dead man's possession.

Inheritance.

The Feast.(Ukupupa)(Icikoloti)(Mweezyo).

_ Spouse crawling around the house (Muyeni)

- Shaving hair off(Kugela)

_Dancing ghosts(Nyau)

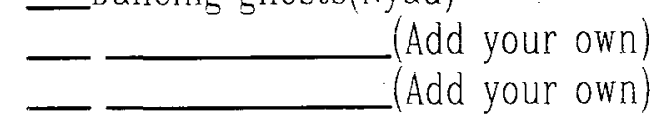

On spaces provided please answer the following short questions

1. Do you feel there is any activity Christians should not participate in?

Explain briefly (use the back of this paper)

2. Has your Church studied any of these in the light of the Bible?<smiles>C[As](C)(C)[Mg]</smiles>

3. Out of each section choose one(1) about which you would want to have a Bible Study.

Section A

Section $B$

Section

4. Out of all the items in sections A.B and C. choose one you best know about and explain it in detail. (use the back of this paper).

5. Out of all of the items listed which ones pertain to fear or respect of spirits? Explain briefly.

6. Do you think the Church should address some of these issues? Yes. 
No.

If your answe: is yes, How should the church do it? explain briefly. 
APPENDIX C

MAP OF ZAMBIA 


\section{MAP OF ZAMBIA (Tribal Settlement)}

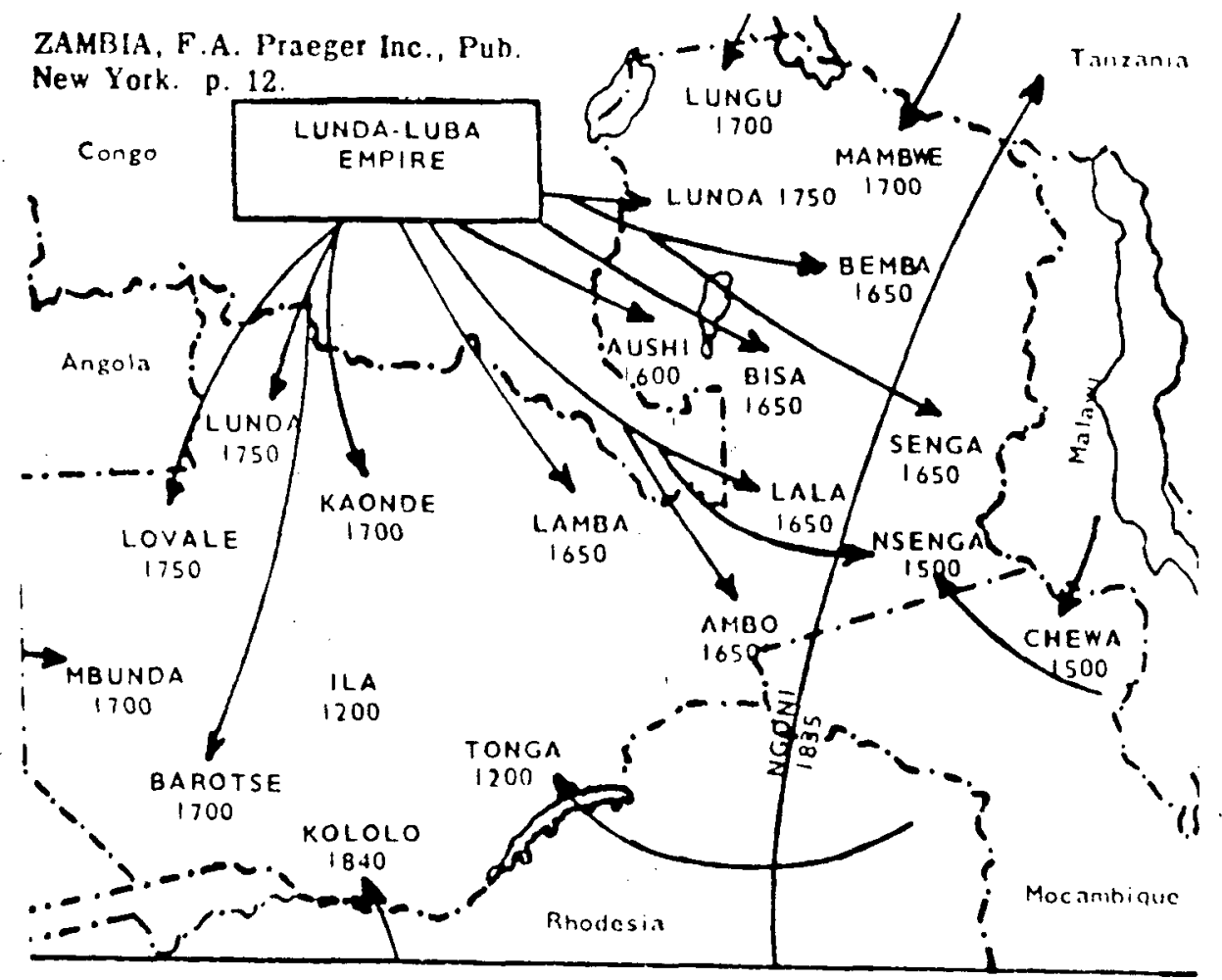

Routes by which Zambia's principal tribes reached their present homes, with tentative migration dates 


\section{APPENDIX D}

NEWSPAPER CLIPPING ON

FUNERAL PRACTICES 
NEWSPAPER CLIP (Funeral Practices)

TIMES OF ZAMBIA, Wednesday, Novemoer 15, 1945

FEATURES

\section{Women act to safeguard}
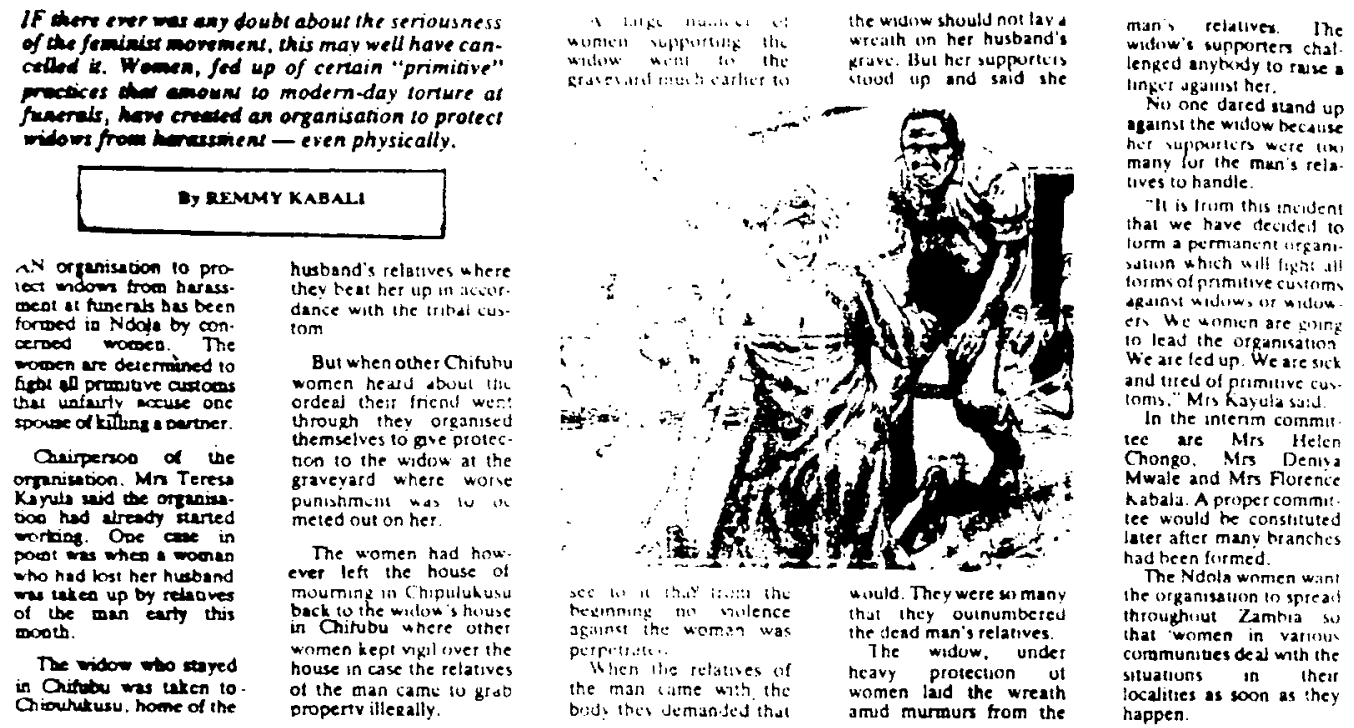

\section{their interests}

The wumen sald there were many laws that pro tecied wumen but were not being implemented because women who wete
attected wete nut pruperly organised.

In the past. there was a custum - llit actuxid aus dink. If thit person died. that wds prewh that ne ur he us gulty of an
offence. It wascalied "um. offence. It mascalied "um. havit done awas with this have done away with this
custum because il is pnmicustum

\section{PRACTISED}

The women said promitive customs must be were practised by local tribes.

Mrs kavula pointed out that in Bemba, fot exam. ple. there was a custom calted "ukusona bandic Acoording to this custom when a person died hun ters would be asked to $k_{i l l}$ the animel they rulted female the worman was blamed for the death ind if the animol was male the man's

blame. Male and is wos time that women tough gainst oppression when organisation should be organianion should be Zambia." she said. Mrs Kayula sayd men
should aiso realise that their relatives will strin their houses bare and throw their children out Men too. who really live their ehildren. nicid in support our organisation. customs whe some triso haras customs which also hatass stand up and fight. On our par, war has stared we ate not gong to be making resolution after making tion. We have starict act ing and we shall continue acting. "Mrs Kavula said The widow who under went beating has dis joined the organisation and will be co-opted in the The cownsee. leace are already there and there is no need to pass resolutions agains nolence. they said. Theie are many tuneral " policemen cannot be houses but organixed homen bust all tranised heip stop violence," the said.

\section{POLITISATION}

The women ruled agannst politicisation of
the association. The name the association. The name of the organisation is Pro-
tectuon of Widows Agaist Primitive Customs Agast Primitive Customs

custom whibes a were is torced 10 do a leopard crawl on her knees and ellorws when the husband dess. The woman is denued food or water for some

days. big conferences to erado. cule. The law does on lured al we womeno co do is to phys ally iocesvene and ston the iorture until police come," Mrs

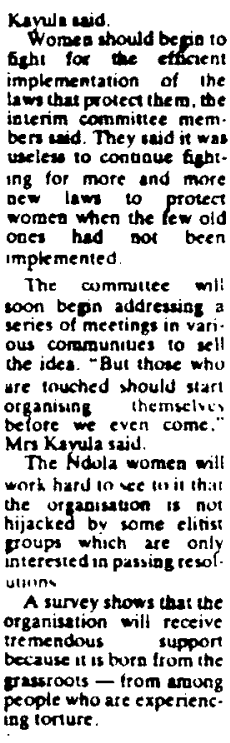

Worces should begio to mplementation of the wo chat protect the m, the ben und They end it was aciew to conanue taght ger more end more vomes when the lew old wes hor been The commultee mil won bepn audrescing a

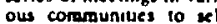
the ides -But thoue who ure touched should star organisug themselvo Mrs Kerula sajd.

women will woth hard io wee it it thit hijacked by some elitist troups which are only tremendous suppon grasroots - from ariong ing torture. 
APPENDIX E

SEMINAR LESSONS 
APPENDIX E

WEEKEND SEMINAR LESSONS

Weekend Seminar Program

Friday: 7:00 - 8:00pm Preliminaries and Introductions.

8:00 - 9:00pm Seminar Lesson 1.

Sabbath: 8:00am - 2:00pm Local Church Program.

$$
\begin{aligned}
& \text { 2:00-4:00pm Seminar Lesson } 2 . \\
& 4: 00-4: 30 \mathrm{pm} \text { Break } \\
& 4: 30-6: 00 \mathrm{pm} \text { Seminar Lesson } 3 . \\
& 6: 00-7: 00 \mathrm{pm} \text { Supper } \\
& 7: 00-9: 00 \mathrm{pm} \text { Seminar Lesson } 4 .
\end{aligned}
$$

Sunday: $8: 00 a m-9: 00 a m$ Worship

$$
\text { 9:00 - 11:00am Seminar Lesson 5. }
$$$$
\text { 11:00 - 11:30am Break. }
$$$$
\text { 11:30 - 12:30pm Seminar Lesson } 6 \text {. }
$$$$
12: 30-2: 00 \text { pm Lunch }
$$$$
\text { 2:00 - 4:00pm Seminar Lesson 7 }
$$$$
4: 00-4: 30 \text { pm Break }
$$$$
4: 30-6: 00 \text { pm Seminar Lesson } 8
$$$$
\text { 6:00 - 7:00pm Closing, Commissioning }
$$ 
And Dismissal.

A note to all seminar participants. You are very welcome to this mission district and we wish you all God's blessings during your stay in this district. Please if you have any question, contact the District pastor of this place he will assist you as much as he is able.

\section{LESSON 1: THE STATE OF THE DEAD}

\section{Issue to Discuss}

Do dead people continue to live on as spirits outside the physical body?

\section{$\underline{\text { Aim }}$}

To introduce the pastors and laity to the Biblical passages that will convince and equip them in the knowledge about the unconsciousness of the dead.

\section{Lesson content}

1. The Bible on Death.

Soul and Spirit.

2. Greek Philosophy.

3. Church History in the middle ages.

4. Group Activity.

\section{Objectives}

After studying this lesson the pastors and laity

should:

1 .

Be able to understand that the dead have no influence on the living.

2. Understand that spirits of the dead are not from the people that die but from some other source.

3. Have a ready made bible study which they can use in 
their local Churches.

\section{Presentation.}

Introduction

How many of us here would be comfortable spending a night in a grave yard? This question was asked by one of the evangelists to a congregation. In response to this question no hand went up. The fact that we can not be at peace at night in the grave yard tell us that many of us still fear the dead.

In our society, we are faced with deaths, and at funerals there are a lot of activities happening.

Activities like cleansing rituals, mistreatment of the bereaved, property inheritance and many others. Some of the activities are quite disturbing like the ones described in a Newspaper clip. [see appendix D] In this article several points come to surface.

(A) Bereaved are subjected to a lot of torture and humiliation.

(B) Belief in spirit mediums to reveal the cause of death.

(C) The Church's silence in reacting to these.

(D) Many people know that these activities are unfair and based on superstition.

We are gathered at this seminar to address such issues and go back with ideas on what to teach the congregations we represent. Our first lesson is helping us understand whether or not, the dead people continue to Iive outside the physical body after they die.

The Bible on Death

Gen. 2:17 The certainty of death.

Gen. 3:4,5 The Devil's lie. There is no death, but continued existence as gods. Many people today agree with this lie that dead people become living gods.

Job 14:10 When a man dies he is nowhere.

Psm 146:3,4 The dead are unconscious. 
Psm $6: 5$

There is no activity in death.

$\operatorname{ECC} 9: 5,6$

The dead know nothing.

These verses build a very strong foundation about the condition of man in death. The dead are unconscious, their love or hate are forgotten and they cannot participate in activities that happen on earth.

Psm 13:3 Death is defined as sleep.

John 11:11-14 Jesus refers to the dead Lazarus as sleeping.

1 Cor 15:6 Paul sees the dead as sleeping.

1 Thess 4:13 Again Paul on the dead as asleep.

Dan 12:12 Resurrection as awakening from sleep.

The dead are certainly not shown as living

somewhere. Much confusion on the certainty of life after death has been brought about by the words soul and spirit, and the influence of the Greek philosophical thought.

Soul and spirit

It is now important to examine the words translated soul and spirit to see if these words in their original meaning carry any idea of a never dying entity.

From the Hebrew old Testament, comes the word

Nephesh. This word is translated, living being. It is also translated to mean life principle. In many cases it is used to describe a person who is alive. This nephesh as describing a living being is shown that it can die. Lev. $19: 28$ and Num. 9:7,10 a dead corpse is referred to as a Nephesh. This is important to understand because it helps learn that the word soul does not carry a meaning of continued existence.

In the New Testament, the Greek word Psuche is translated soul. This word denotes the whole person or life itself. Psuche is not immortal either, it can be destroyed as shown in Math. 10:28. The New Testament word psuche and old Testament word Nephesh both mean a vital principle common to all living beings. In addition to these words come the words translated spirit in both the old and New Testaments. 
The old Testament word Ruach translated spirit is the animating principle of all that lives. It is the power of God which enlivens both man and beast. No human or animal being can live unless sustained by God's life-giving Spirit which is this Ruach.

In the New Testament the word pneuma is translated spirit. From this word comes the term pneumonia, a disease believed by the Greeks to have been brought by an evil wind. It is associated with air. This pneuma, is the power that God bound in man and at death returns to God who gave it.

\section{Greek Philosophy}

Greek philosophy divided the world into two realms, the physical and the spiritual realms. The physical was seen as evil and perishable, while the spiritual was good and imperishable. The human body is part of the physical and hence it dies and rots, while the spirit (inner being) is spiritual and cannot die. It is the part of a person that leaves the body and joins the spiritual realm to continue its existence separate from the body.

Socrates [469-399] assumed that man has a dual nature composed of soul and body. The soul does not die while the body dies. This teaching was picked up by his disciple Plato whose writings influenced Aristotle, the stoics, Cicero, Plutarch Christian fathers, Scholastics and the Renaissance. This belief then was adopted into the church.

\section{Church in the Middle Ages}

Following the Greek philosophical thought of a never dying soul, the Church in the middle ages taught that people who die go to purgatory for soul purification and if relatives pray and pay for them, their souls may go into heaven. This teaching was propagated throughout the world much to the financial benefit of the church and the corruption of the word of God. 
Let us understand therefore that the words translated soul and spirit in both the New and Old Testaments never carry a meaning of a never dying entity. When a person dies he is gone and never exists. The dead have no influence upon the living. The question is what about those spirits that come as demons or as ancestors? If the dead know nothing and do not take part in the activities of the earth, then the demons and spirits that come into our daily lives come from somewhere apart from God. This subject will be dealt with in due course.

\section{Group Activities}

Let us now divide into small groups of say fives. This is how we shall do it, so that we do not group ourselves as we came from our Churches or as friends. We need to mix up so that we can get to know each other better and share a variety of experiences. We will start by counting $1,2,3,4,5$ then start again $1,2,3,4,5$. Then the ones will gather in the left front of the Church. The Twos will be in the right front. Threes in the left back. Fours in the right back and the fives in the middle or center part of the Church. [Group sizes will vary depending on the number of people attending the seminar.]

In our groups, first we need to introduce ourselves to each other. We would like to know where you come from, how many you are in the family and what you do for a living. After that we will get in our first assignment which is to look for five biblical texts, other than the ones we have discussed during the seminar presentation. These texts, should be able to show that the dead do not live on. Each group will choose a secretary who will record and report your discoveries. We shall have fifteen minutes to do this. After the fifteen minutes are over we will come together and give our reports to the whole group. We will then list all the texts from the groups and this way will share information that we will need when we get back to teach in our Churches and the communities. 
Prayer and Closing

At the end this lesson, we will all stand and sing our closing song, after which prayer will be offered. Recommended Reading

White, E. G. The Great Controversy. Boise, Idaho: Pacific, 1950.

1940.

The Desire of Ages. Boise, Idaho: Pacific,

Seventh-day Adventist Believe. Hagerstown, MD: Review \& Herald, 1988 .

Dwyer, John C. Church History: Twenty Centuries of Catholic Christianity. New York: Paulist, 1985.

Morris, Geo. S. Philosophy and Christianity. New York: Robert Carter \& Brothers, 1975.

Page, Allen. Life after Death: What the Bible Says. Nashville: Abingdon, 1987. 


\section{Issue}

What is wrong with ancestral veneration? Are the spirits really called back into the society to protect their relatives?

\section{Aim}

The aim of this lesson is to show the difference between ancestral worship and ancestral veneration and show the danger in relying upon the revelations of spirit mediums.

\section{Lesson contents}

1. Definitions.

2. The Bible and Ancestors.

3. Group Activity - Traditional ancestral veneration. Christian alternatives to ancestor worship.

4. Spirit mediums and spiritualism.

5. Ellen $G$. White on spiritualism.

6. Question and answer session.

\section{objectives}

Seminar participants should be able to:

1. Find the difference between ancestral veneration as found in the Bible and ancestral worship as practiced in traditional circles.

2. Select good activities pertaining to ancestors and discard the superstitious ones.

3. Be stimulated to seriously review all the traditional practices they know of in the light of the Bible and what has been studied.

4. Have a ready made Bible study to use in their local Churches and their communities. 


\section{Presentation}

\section{Introduction}

Last period we dealt with the question of the state of the dead. We learnt that the dead are gone no more to return. The dead have no more dealings with the living. They can cause no harm or danger neither can they protect any one of the living. The questions we left unanswered were, what about the spirits of our relatives and demons? Is there anything wrong with ancestral veneration? What spirits are those that seem to protect and bring rain at the people's performance of rituals?

Let us open our meeting by the use of our theme song. After the song I will ask all to kneel in twos and call upon the Holy spirit to guide in our study this afternoon.

\section{Definitions}

Let us begin our study by definitions that will help clarify some issues. What is ancestral worship? What is ancestral veneration? Worship is reverence offered a divine being or supernatural power. Worship is to regard with great devotion to a being of esteem.

Veneration is respect given to someone of high status or elderly. Veneration includes remembrance. To make a distinction, worship is given to God because he is the only supernatural, prime mover. Veneration is respect given to any person, dead or living. This includes emulation of the words, actions and works the elders living or once lived, did that were outstanding in the community and for the people's benefit.

The Bible and Ancestors

Gen. 5:10,11 Genealogies from Adam to Abram. These people kept records for remembrance.

Ezra 7:1-5 Genealogy from Aaron to Ezra.

Math. 1:1-17 Jesus' genealogy revealed. 
Scripture allows that the dead be remembered by the living.

Ex. 6:2-8 Jehovah is called God of Abraham, Isaac, Jacob.

Deut. 21:18-21 Filial piety for parents.

Gen. 35:20 Pillar for Rachel's remembrance.

2 Sam. 18:18 Absalom's monument.

Math. 26:19, 26-29 The Lord's supper reminds us of Christ our ancestor.

Jews were proud of their great

founders of faith and ancestors.

John 8:33 Abraham is seen as a great father

unequaled. He is a forefather or ancestor. David also was highly respected or venerated although he was long dead. Jesus was even called Son of David (Mark 10:47).

Ancestral veneration becomes bad when it starts placing ancestors in the place of God. When it starts believing that the dead ancestors return home in a nonphysical state, more powerful than before, and we ought to solicit help from them as from God. This breakes the law in Ex $20: 3$.

\title{
Group activity - Traditional Ancestral Veneration.
}

We will break into our small groups again. Please remember those groups we were in yesterday, groups of fives. In these groups we will discuss these questions; (a) list some ways we venerate our ancestors as Zambians. Example we keep their photo in our albums. (b) what can we have as alternatives to ancestral worship? Let us use fifteen minutes to do this.

We will take 10 minutes break. After break we will continue with: what about spirits that cause sickness and death?

\section{Spirit Mediums and Spiritualism}

\author{
Gen. 3:1 First seance - devil in a serpent. \\ The devil's schemes are subtle and \\ crafty. \\ 1 Tim. 4:1 Last days warning about seducing
}


spirits.

Rev. 16:14 Spirits of devils.

2 Thess. 2:9-12 Satan working with power.

2 Cor. 11:14-15 Masquerading spirits.

1 John $4: 1 \quad$ Test spirits.

Isa. 8:19-20 Test of a true spirit.

Lev. 19:31 God forbids the practice of spiritism.

Deut. 18:10-12 Necromancy - Communication between the dead and the living condemned by God.

1 Sam. 28:3-25 Samuel consulted a seance with disastrous results (1 Chr. 10:13,14; 1 Sam. $31: 1-6$ )

Points Noted

Spirits that seem to help us are spirits of the devil. The devil has power to work miracles through the spirits. It is important to note that God expressly forbids any alliance with these who practice divination. These spirits can pretend to be of help and do good but they end up causing more harm than good.

\section{Ellen G White's Statement on Spiritualism.}

"I saw that the saints must have a thorough understanding of the present truth; which they will be obliged to maintain from the scriptures. They must understand the state of the dead; for the spirits of devils will yet appear to them, professing to be beloved relatives or friends, who will declare to them unscriptural doctrines. They will do all in their power to excite sympathy and will work miracles before them to confirm what they declare." EW 262

Here is a warning that we need to take seriously. The spirits will use lying power especially in these last days to deceive those who do not study the word of God. 
Question Time

On this note we would like to pause for questions and contributions. After the question and answer time, we will close our lesson with a song and prayer.

Recommended Reading

White, E. G. Early Writings. Hagerstown, MD: Review \& Herald, 1945 .

Mbiti, John S. African Religions and Philosophy. Oxford: Heinemann, 1990 .

White, E. G. The Great Controversy. Boise, Idaho: Pacific, 1950 .

Wendland, E. H. Of other Gods and other spirits.

Milwaukee: Northwestern, 1977. 
LESSON 3: POWER ENCOUNTER

\begin{abstract}
Issue
A lot of what is practiced at funerals and thereafter is associated with fear of evil spirits and demonic influence.
\end{abstract}

\title{
$\underline{\text { Aim }}$
}

The aim of this lesson is to introduce seminar participants to the miracle healing power of Christ and the authority to cast out demons that He left to the Church.

\section{Lesson Content}

1. The reality of demons.

2. Masquerading demons.

3. Our power and authority.

4. Power and Healing in early Adventism.

5. Fear of fanaticism.

6. The latter rain.

7. Group Activity - Prayer session for the Holy Spirit.

\section{objectives}

able to:

By the end of the lesson, participants should be

1. Start serious prayer encounters leading to removing doubt and fear of spirits.

2. Start deliverance ministries in their local Churches.

3. Go back to their local churches convinced that it is God's will to drive out demons and heal the sick.

4. Begin to exercise faith in praying for the sick and demonized, and expect God to honor their prayers and heal the sick. 
Presentation

\section{Introduction}

In the last session we noticed that the devil will increase his lying wonders through demonic forces called spirits. In our Zambian situation, the devil has caught us into believing that the dead are still alive and can have effect on our lives. He has through witches, mediums and spiritists come up with a lot of ritual activities aiming at instilling fear in us so that we can believe that without rituals we are doomed.

Today we want to discover that He that is on our side is greater and much more powerful than the demonic forces. We have the authority to cast out demons, bind demons so that they may have no influence on us at all.

\section{Reality of Demons}

Acts 16:16-18 The demonized slave girl.

1 Cor. 10:21 Table of demons

2 Cor. 4:4 Demons blinds those who do not believe.

1 Tim. 4:1 Teachings of demons.

John 14:30 Jesus refers to the devil as ruler of this world.

Eph. 2:2 Paul sees the devil as ruler of spiritual powers in space.

1 Pt. 5:8 The devil as a roaring lion seeking anyone to devour.

1 John 5:19 The devil as one who rules the whole world.

Eph. 6:12 Wicked spiritual forces in the world.

The verses we have read makes it clear that satan has a powerful kingdom that Christians must reckon with at every turn. He has various strategies that Christians must be know and be prepared to counter. 
Math. 12:43-45 They seek to live in people and use human bodies as instruments.

Mk. $9: 17-29$ They have different personalities and are destructive.

Mk. 5:4 \& Mth. 12:45 They differ in power, some are more evil and destructive than others.

Lk. $13: 11$ They affect health.

Lk, $8: 22-25$ They affect weather.

We must understand that the devil is tricky and subtle, he can cause rain to come down, that is why we should never be surprised when we hear of some witch, medium or chief who is able to make rain. The devil uses such instrumentalities to get through to us to redirect our homage from God.

\section{our Power and Authority}

Regardless of what the devil is able to do; we as Christians are equipped with the heavenly arsenal to combat and be victorious over these demonic forces.

Lk. 4:18 Jesus was sent to set the captives free. We are also sent to set the demonic captives free. Let us note that when Christ commissioned his followers to preach the kingdom of God, he also commanded them to heal the sick and cast out demons (Lk. 9:1,2; 10:8,9; Matt. 10:7,8; Mk. $6: 12-13)$

As Adventists, we love Jn.14:15 and 15:10, keeping God's commandments is on top of our priority list in spiritual matters. Does it not surprise us that many of us are not keeping the command to pray for the recovery of the sick and cast out demons? Read again Lk, 9:1-2 and Matt. $28: 20$, God expects us to use his power and authority to cure diseases and drive out demons. Apparently every believer is empowered to do this. God expects each one of us to exercise our faith.

Some illnesses are brought about by evil spirits. That is why healing and casting out demons must go hand in hand. Although healing may not seem to be wide spread among Adventists today, this does not mean, the church does not believe in deliverance and healing. Note healing in early 
Adventism.

Power and Healing in Early Adventism

Healing and joyful manifestations were believed by Adventists to be evidences of the presence of God. The power of the Holy Spirit was not a mere theory, many people were healed as a result of prayer. Ellen white notes that those who prayed also gained victory over evil spirits.

"The careless and indifferent who did not join with those who prized victory and salvation enough to perseveringly plead and agonize for it did not obtain it, and they were left behind in darkness, and their places were immediately filled by others taking hold of the truth and coming into ranks. Evil angels still pressed around them but could have no power over them." EW 271

Note that in the vision E.G White saw that Christians were victorious over evil spirits. They believed in prayer for healing, She again points out that disease brought by evil spirits can and even today be healed by Christ.

"When evil spirits rend a human frame, Christ feels the curse. When fever is burning up the life current, He feels the agony. And he is just as willing to heal the sick now as when he was personally on earth. Christ's servants are His representatives, the channels for His working. He desires through them to exercise his healing power." DA. 824

Ellen white related the healing of Brother Mead's sister's child and Brother Baker who had a heart disease. Letter H-8 1851. There are many instances of miracle healing that can be recounted in early Adventism. The Church today seem to have lost that power - why?

\section{Fear of Fanaticism}

As time progressed, Ellen white saw a danger in people relying on manifestations and leaving the word of God and she warned against such. There were cases like the 1908 one, in which Ralph Markin and his wife were involved in fanatical exercises. Ellen white warned them and the believers. While some people took her warning to an extreme 
so much that they gave up efforts of strong prayer and healing sessions, others were prejudiced against the visions of Sister white and became unwilling to follow her counsels. This was the beginning of the decline of power manifestation. Ellen white did not wish for a decline of power manifestation, but the leadership of the Church fearing fanaticism, and in an effort of drawing people to reliance upon the Bible, discouraged what ever seemed fanatical. Following this, the state of spirituality lowered and worldliness increased. The Church thus lost its vital religion, and the power of the Holy spirit was less and less manifested.

The Latter Rain

According to the promise of Joel 2:12-32, the Spirit will be poured upon all flesh in the last days and miracles will be wrought. Sr. White adds;

"Miracles will be wrought, the sick will be healed, and signs and wonders will follow believers. Satan also works with lying wonders, even bringing down fire from heaven in the sight of men. Thus the inhabitants of the earth will be brought to take their stand." GC 612

The time of the latter rain is now. God is waiting on us to receive and exercise our faith by putting our knowledge into practice, remove fear of ridicule, and fear of failure. Let us to trust his word and exercise faith.

Group Activity - Prayer for the Holy Spirit.

It is time to break into our usual groups. In these groups we will focus our discussion on: What shall we do now to receive the latter rain that will enable us to defeat demonic forces? At the end of our discussion I would like all to pray for receiving the Holy spirit. After every one has prayed I will close the prayer session. From that time on we will start to exercise our faith in casting out demons and healing the sick.

I will ask anyone with an ailment to come forward for prayer healing. We will pray and believe God for the healing of whoever will be in need. 
Recommended Reading

White, E. G. Ministry of Healing. Boise, Idaho: Pacific, 1942 .

Kraft, Charles. Defeating Dark Angels. Ann Arbor, MI: Servant, 1992.

Murray, Andrew. Devine Healing. Springdale, PA: Whitaker, 1982 .

White, Arthur. L. "Charismatic experiences in early seventhday Adventist History" A reprint of twelve articles published in the Review and Herald, August 10, 17, 24, 1972; March 15, 22, 29 April 5, 12, 19, 26, and August 2, 9, 1973. Ellen G. White Research Center. Andrews University, Berrien Springs, Michigan. 
LESSON 4 : CLEANSING RITUAL

\section{Issue}

Why do so many Christians participate in rituals that contradict what the scripture reveal? Do they understand the implications of the cleansing rituals?

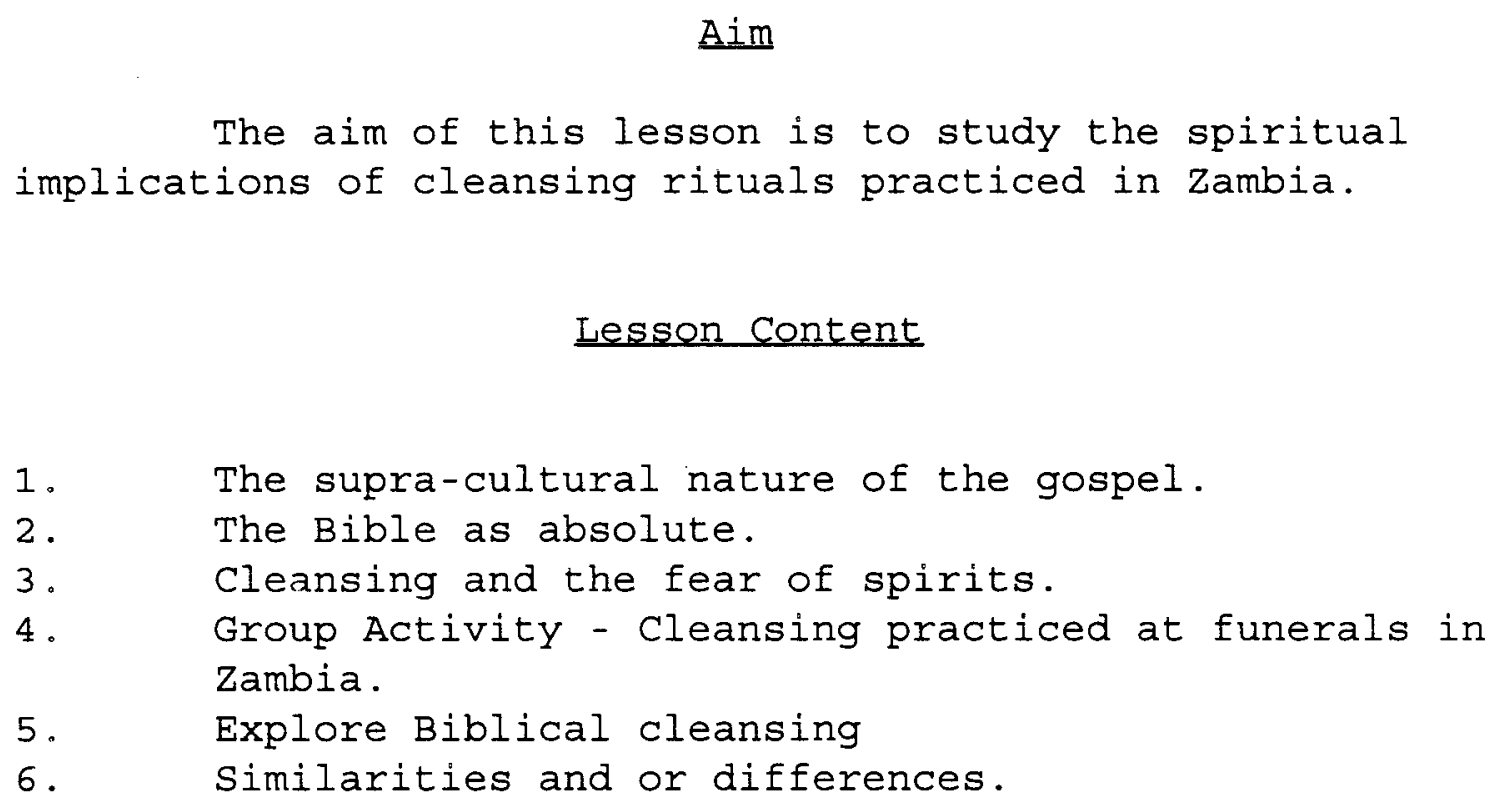

\section{Lesson Content}

1. The supra-cultural nature of the gospel.

2. The Bible as absolute.

3. Cleansing and the fear of spirits.

4. Group Activity - Cleansing practiced at funerals in Zambia.

5. Explore Biblical cleansing

6. Similarities and or differences.

\section{objectives}

At the end of the study, participants should be able

to:

1. See the evil involved in cleansing rituals associated with death.

2. Strengthen their confidence in the word of God.

3. Understand that cleansing as the Bible views it, is different from the cultural cleansings.

4. See clearly that adultery or fornication is still sin even when done as a cultural practice. 


\section{Presentation}

\section{Introduction}

There are many cleansing rituals in our society. These rituals are done in different ways and at various occasions. One such occasion is the funeral. I am sure you know many rituals done at funerals more that I do. In a little while today we will break into our small groups and discuss the many cleansing rituals done at funerals that we are acquainted with. One example of such rituals is sex with a relative of the deceased. There are two basic reasons why this and similar rituals are done. First, is to drive away the spirit of the dead. Second, is to maintain the tradition, because it has always been done this way, it is our culture.

Can such cleansings really drive away the spirit of the dead? Are we going to do these rituals just because it is our heritage even though it contradicts Christian norms?

The Gospel of Christ is supra-cultural.

Every culture has an inbuilt change mechanism. As long as people live and move, culture will always be dynamic. Since culture includes what people eat, how they dress and activities they are involved in, as long as these things are not static culture will always change.

Christ came to transform culture through transforming lives. As sinners are redeemed, cultures' perverted good is also freed of its perversion. Every culture must be measured by the Christian Gospel of Christ. Every culture stands to be judged by Christ. Because of this, the Bible as the revealed will of God must be taken as the absolute rule of faith.

The Bible as Absolute.

The Bible is the voice of God. We need to heed to what the Bible says.

2 Tim. 3:15-16 The purpose of the scripture.

2 Pt. 1:21 The author of the Bible. 
1 Pi. $1: 25$

Jn. $5: 39$

Matt. $24: 35$

never
The word endures forever unlike culture that changes.

The Bible testify of Christ and cannot change.

The Bible is absolute, it will

We can therefore rely on this Bible because it has stood the test of time. In every situation the Bible has power to correct, rebuke and guide.

\section{Cleansing and fear of spirits.}

The cleansing sex ritual is done to appease the departed person's spirit and to prevent sickness and possible death. Fear is therefore the driving force to these practices. Many of our church members are pressured into such cleansings, and yield to the pressure, because they fear being ostracized, and also the possibility of the spirit coming to haunt them. Some go in secret to be cleansed, because they fear church discipline.

In the light of what we have learnt, we have power and authority to cast out demons. We can step our foot down and forbid the evil forces from having any power over the bereaved. It is my suggestion therefore; to at the end of the burial dedicate the bereaved and command the evil spirits not to enter their lives.

Group Activity - Cleansing practiced at funerals in Zambia.

For our group activity today, we will discuss and list various cleansings practiced at funerals in your community. Second, find reasons why these are done. After thirty minutes of your discussion we will break for ten minutes.

Explore Biblical Cleansing.

Now that we have known some of our traditional cleansings, we want to know what the Bible says about cleansing. 
Lev. 15:1f Various water cleansings

Num. 19:1f More water cleansings

Lev. 16:5f Blood cleansings

Human corpse possesses the highest power of defiling whose cleansing is done by water and seven day quarantine. Other defilements are cleansed by water and up to sunset isolation. Defilement that had to do with sin was cleansed by the blood. Water cleansing may have to do with hygiene and prevention of cross contamination. These cleansings had nothing to do with the fear of spirits of the dead.

\section{Similarities and or Differences.}

At this time we shall compare the lists that we came up with in our small groups. Together we will determine which cleansing rituals are mere sanitary or hygienic and which ones are aimed at appeasing the spirits of the dead. This should take 15 minutes.

It seems inevitable to discard whatever has to do with spirit fear and keep what supports hygiene and cleanliness. It is important to note that every culture has norms. Not everything in culture is bad and evil, some of the practices in our culture are good and need to be encouraged. We need however, to test everything done culturally by the unchangeable word of God, then discard what is evil and keep what is worth.

$$
\text { Prayer and dismissal. }
$$

\section{Recommended Reading}

Bubeck, Mark I. The Advesary: The Christian Versus Demonic Activity, Chicago: Moody, 1978.

Larkin, William, Jr. Culture and Biblical Hermeneutics. Grand Rapids: Baker, 1988.

Sperling, Abraham I. Reasons for Jewish Customs and Traditions. New York: Bloch, 1968. 
LESSON 5: BEREAVED MISTREATMENT

\section{Issue}

Is it justifiable to humiliate the bereaved and blame them for the death of the spouse?

\section{$\underline{\text { Aim }}$}

The aim of this lesson is to show the evil and unfairness involved in various activities aimed at causing physical pain, humiliation, and embarrassment of the bereaved during or after the funeral.

\section{Lesson Content}

1. Grooup Activity - How the bereaved are treated during the funeral period.

2. The Bible and Widow mistreatment.

3. The gospel and culture change.

4. How to bring about change.

5. The Church's participation.

\section{objectives}

At the end of this study participants should be able to:

1. Make a stand to follow what the Bible reveals without fear. Follow the example of some Bible characters who stood alone though it was not a popular thing to do.

2. The local churches should start standing with the bereaved and protect them from those who may wish to torture them, and humiliate them according to culture. 


\section{Presentation}

Introduction

I would like to share with you a news clip from the Times of Zambia November 151995 issue. This clip shows that the issues we are dealing with are current and very much alive in this century. [see appendix D]

I believe there are many ways people are treated unfairly in our societies at funerals. Example letting the bereaved crawl towards the funeral house or around the house. The other is beating up the bereaved. Why are such activities done? This morning we will discuss these and look for Biblical solutions or reactions to such practices. At this time, we will start with our group participation.

Group Activities - Cultural Mistreatment of the Bereaved.

Let us go into our groups of fives as usual and list down all the treatments you are aware of, done to the bereaved. I would like you to list the ways that you think are alright and can continue and which ones are not good and need to be discarded and why. After we come together we will share with the rest of participants. We will take 15 minutes to do this.

The Bible and Widow Mistreatment

In most cases women suffer much more than men during funerals. The Bible has some principles we need to look at. Deut. 25:5-10 The levirate to raise children for the widow.

Gen. 38:8-10 Penalty for refusal to care for widows

Ruth 2:20 Care for widows

Gen. 38:26ff Social status of a married woman

Mk. 12: 18-27 Jesus asked John to care for his mother who had no husband.

The principle we do not want to miss is that the levirate was God's method through the cultural practice of caring for the widow. 
Ex. $22: 22$

Deut. $10: 18$

Ex. $34: 11-16$
God commanded never to mistreat a widow.

God will defend the widow.

God counseled not to imitate the

detestable ways of Canaanites. Christians are supposed to get some principles from the Bible and live by those standards even if the society may dictate otherwise. It is important to remember that God is more sympathetic and on the side of widows than humans demonstrate.

\section{Gospel and Cultural Change}

What are we Christians supposed to do about these unfair practices that are so prevalent in our society? There are several ways of looking at the gospel in relation to culture.

(a) Gospel against culture - This stresses the opposition between the gospel and the society. This view does not see anything of value in culture. It sees the gospel as there to remove culture completely.

(b) Gospel of culture - This view plays down, or fails to notice any marked difference between the gospel and cultural ways.

(c) Gospel transforms culture - This view examines culture and lets the gospel speak to the evil practices in culture and change them for the better. Christ is the transformer of culture. Christians are God's representatives to transform culture in every society they are found.

(d) Gospel above culture - The word is so much above culture that it contributes nothing to culture, and has nothing to do with culture.

(e) Gospel and culture in paradox - This recognizes authority in both the gospel and culture. A Christian has to obey both, but finds tension existing in between gospel and culture.

In conclusion, a believer will always recognize the superiority of the Gospel. The Gospel is there to speak to all the cultural practices and transform culture. Paul in 1 Thess. 1:9 reveals that the gospel is to turn people to serve the living God. Acts 26:17-18 Believers are sent with the gospel to open other people's eyes and turn them 
from darkness to light. Therefore, the gospel and God's word stands to transform culture.

How to bring about change.

(a) Revitalization - This is organized, deliberate and conscious effort by the church members to create fair practices that are satisfying to the bereaved.

(b) Reinterpretation of practices - This is where Christians start new practices which other members of the society would view as reality, be able to compare this new practice with the old, and learn to accept the new as a much more satisfying practice.

(c) Power encounter - This is a spiritual encounter that exposes the weakness of the enemy by unleashing God's power against the enemy. This confronts non-Christian elements in society rather than allowing these practices to go on unchecked.

The Church's Participation.

Christians must stand up and speak against unfair practices. It is a denial of faith for the church to sit down in silence while the bereaved are being mistreated at a time they need comfort most. Dorcas societies must take an active role in educating their communities about the unfair non-Christian practices.

How will you take this message to your churches to bring about change at funerals? What steps are you going to take? Let us share ideas.

Prayer and Close.

\section{Recommended Reading}

Rheenen, Gailyn Van. Communicating Christ in Animistic Contexts. Grand Rapids: Baker, 1991.

Hiebert, Paul. Anthropological Insights for Missionaries. Grand Rapids: Baker, 1985. 
Mayers, Marvin K. Christianity Confronts Culture. Grand Rapids: Zondervan, 1987. 


\section{LESSON 6: PROPERTY INHERITANCE}

\section{Issue}

When a married man dies, many widows are left with absolutely nothing of the property acquired together with the husband. Traditionally, it has been assumed that all property in the house belongs to the man. That is why when a man dies all the belongings in the home are shared among the man's relatives without any consideration of the widow.

\section{Aim}

The aim of this lesson is to sensitize the seminar participants to the evil and unfairness of this cultural practice.

\section{Lesson Content}

1. Property distribution in the Bible.

2. Marriage unity and property acquiring.

3. Group Activity - Explore what happens during inheritance in the traditional setting.

4. Legal aspects of the rightful owner of property after the death of a spouse.

5. A plan to help protect widow's at the local church level.

\section{Objectives}

At the end of the study participants should be able to:

1. See the evil in the cultural practice of grabbing the widow's property.

2. Understand that both biblically and practically the rightful owner of the property is the wife.

3. Take marriage seriously.

4. Start taking steps in letting the church at the local level be the voice of the voiceless suffering 
widows.

\section{Presentation}

Introduction

In our society today women suffer greatly after the death of a husband. The relatives of the husband come in and collect every item in the house leaving the woman alone, lonely and poor. They even go to the bank and get all the money. One thing these people forget is that the widow and children participated in the acquiring of that wealth.

During this session, we will discover what it means to be one and what the Bible has to say about the deceased's property. We have invited a lawyer who will educate us on some legal implications involved in the issue, and legally the right owner of the property at the death of a married man.

Property distribution in the Bible.

Let us go right into the discussion for today. What does the Bible say about the deceased's property?

Num 27:5-11 Sons, daughters, brothers get the property.

Deut. 25:5 The one who marries a widow if not part of the deceased's relation is not counted in the property inheritance.

In the Jewish economy, sons took the property so that they can care for the mother.

Ex. 22:22 God dislikes those who take advantage of widows.

Deut. 10:18 God defends widows.

Acts 6:1 Provision for widows was one of the top priorities in the early church.

James 1:27 True religion is defined by the care given to widows.

It is therefore a denial of Christian faith to fail to speak against injustices committed by the society against the bereaved. 
Marriage and Property.

When people get married, they become one, everything they acquire is theirs. Both husband and wife are seen to be equal. The amount of time and effort put into the building of their marriage and home is equal. They both contribute to the home. Therefore, if one partner dies, the one surviving is the right owner of the property.

Gen. 2:18-25 Suitable helper signifies equality and friendship, and becoming one is forming an indivisible union.

2 Cor. 6:14 Equally yoked.

Mark 10: 6-9 What God has joined together becomes one not two. They have a unity of purpose.

While people are alive, Christians are supposed to do things together, we encourage that families work together as a team. For this reason the church should react strongly to the assumption that everything was done by one person in the family and now that he is dead, his property can be dispensed of at the will of his relatives.

\section{Group Activity - What happens during property inheritance.}

For our group activity this time, we are going into our small groups. We are going to discuss; (i) what happens during inheritance procedures traditionally. (ii) Why property is taken away from the widow the way it is done.

After thirty minutes, we shall come together. The group secretaries will report to the rest of us what they came up with. Following this, will be an open discussion over the same. This session opens our eyes to the evil and unfairness of this unchristian practice. Male seminar participants will be encouraged to put themselves in the predicament of widows. They will be asked what they would like to see done if they were women about to be subjected to this kind of brutality. Then we will invite one or two widows to share their experiences. This is aimed at sensitizing the men and move them to act as voices for the widows when they go back to their local congregations. 
Legal aspects to property ownership

We have invited a lawyer who at this time will

address the issue from the legal view point. The questions we want to ask are; (i) are there laws in this nation to protect the widow and her property? (ii) what legal steps can a widow take or husband before he dies, to ensure that property remains within the immediate family?

\section{A Plan to help widows at the local church level}

Seminar participants will now brainstorm for ideas to help protect the goods of the widows. How shall the church stand and take on the pressure from unchristian relatives to protect the rights of their Christian widow? This is only a start. Each seminar participant will be encouraged to take the ideas presented and share them with the local churches. In the local churches, the Adventist Men Organization and Dorcas societies will discuss and perfect strategies as they see fit for their situation.

Prayer and end of lesson.

\section{Recommended Reading}

Tetlow, Elizabeth Meier and Louis Mulry Tetlow. Partners in Service: Toward a Biblical Theology of Christian Marriage. New York: University of America, 1983.

Phypers, David. Christian Marriage in Crisis. Whitstable, England: Marc Europe, 1985.

Youngberg, John and Millie. Marriage Commitment: Participants Manual for marriage commitment seminars. Berrien Springs, MI: Andrews University, 1990. 
LESSON 7: HEADPOINTING AND FAMILY BURIAL GROUNDS

\section{Issue}

There are certain burial places that are taken to be so important that if a person is not buried there the relatives are concerned. It is the same way with where the head points at burial. Direction is so important that it sometimes brews quarrels at burial.

\section{$\underline{\text { Aim }}$}

The aim of this study is to introduce to seminar participants to the issues involved in traditional familial grounds and burying with the head pointed a particular direction.

\section{Lesson Content}

1. Group Activity - Traditional burials.

2. Totemism and The Clan.

3. Bible Burials.

4. Resurrection and Burial.

5. Zambian Adventist Burial practices.

\section{Objectives}

By the end of this study, seminar participants should be able to:

1. Come up with reasons why certain burial areas are preferred.

2. Find out whether headpointing or grave site proximity to residential areas is necessary or not.

3. Come up with the solution in a situation where people feel strongly that the head should point a certain direction that differs from the accepted Adventist direction. 


\section{Presentation.}

Introduction

Whenever death occurs in our societies, there is no discussion on whether to or not to bury. Burial is obvious. There are differences however, on where to bury or where the head should point. This is important otherwise there would be no bickering about it. During this study we shall try to understand why culturally headpointing is important, and then find out what the Bible has to offer as principles to clear the issue.

Group Activity - Traditional Burials.

We would like to seek and understand why in our culture certain rules must be followed when it comes to burial. Example, why are twins buried near an ant hill in the Bemba tradition. Why do we bury a twin with a maize cob or banana stump, if the other twin still lives. Why are some buried near houses while others are taken far away to a common cemetery. Finally why do some people insist that the head point the west while others argue for the east.

These are just some of the issues we need to discuss and find traditional reasons for. We will first go into our small groups this morning, in which we will review our traditional ways of burial and find reasons why people bury in their way, why certain directions are preferred over others. We will take fifteen minutes.

We have invited an expert in some of these cultural burial issues. This person will share with us some of what he knows about these practices. The expert will go through what you came up with in the small groups and perhaps add some and give reasons for their existence.

Totemism and the clan.

Some scholars give the reason of totemism and the clan system. They say that the direction where the head points is the direction to the place of origin of their 
ancestors. So when a person is buried with the head pointed towards the origin of the ancestors, his soul will rest with the ancestors and his spirit will travel to join them.

Tribes are divided into clans. Each clan adopts an emblem by which everyone is called, it could be an instrument, animal or objects like the sun, moon and rain etc It is believed that the people who belong to the same clan bearing a common totem are related. It seems therefore true that these people may have belonged to one group before migration and disintegrations. It is interesting to note that people belonging to one clan prefer the head of the dead to point one direction. Some in the Ngoni tribe, who bear similar totems have their dead to point one direction. This probably has to do with the relationship between the living and the dead. The dying have to be buried facing a certain direction for easier move to their place of origin, as a clan.

\section{Bible Burials}

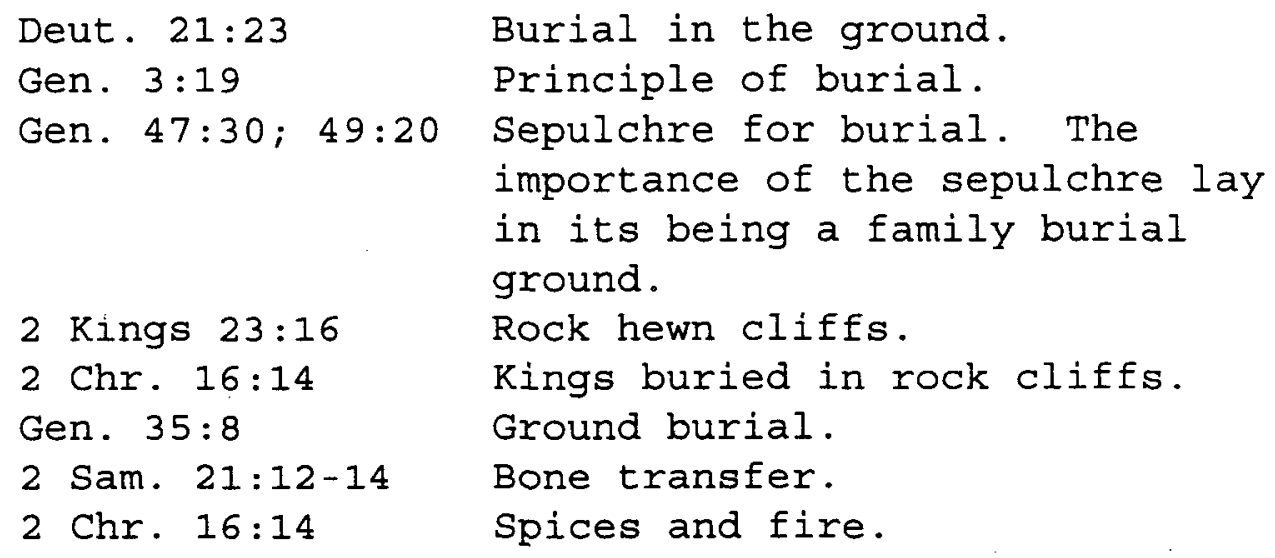

Points: The burial grounds in the Bible were cliffs in the mountains, sometimes, rocks were hewn to make room for the body. Direction of the head was not an issue.

\section{Resurrection and Burial.}

The Jews and Christians believed in the resurrection. They buried their dead with the hope of bodily resurrection. 
Job $14: 13-15$

Psm. $49: 15$

1 Cor. $15: 1 \mathrm{f}$

1 Thess. $4: 13-18$

Isa. $26: 19$

Once we understand the certainty of resurrection for believers, there would be no concern about the head direction, nor the place where burial is to be. With the understanding of the state of the dead in reference to spirits, the dead do not rise to go to the place of ancestral origin. The dead do not know anything, therefore, head pointing should not be an issue.

\section{Zambian Adventist burial Practice}

The Zambian Adventists have an unwritten practice of the head pointing to the west. The reason being that since Christ comes from the east, the Christians at the resurrection should be able to see him coming as they rise. Adventists, however follow the practices of the local place and do not make an issue out of the directions. At the resurrection, every eye will be able to see Christ regardless of burial position.

\section{Question and Answer}

The time for questions will follow this presentation. After the question time is over, the officiating pastor will close the study with prayer.

\section{Recommended Reading}

Ro, Bong Rin, ed. Christian Alternatives to Ancestral practices. Taiwan, Asia Theological Association, 1985.

Riemer, Jack, ed. Jewish Reflections on Death. New York: Schoken, 1974 .

Seventh-day Adventist Believe. Hagerstown, MD: Review \& Herald, 1988 . 
General Conference of Seventh-day Adventists. Seventh-day Adventist Church Manual. Silver Spring, MD: General Conference, 1990. 
LESSON 8: A FUNERAL LITURGY

Issue

Can there be a contextualized funeral liturgy?

\section{Aim}

The aim of this lesson is to introduce participants to principles and steps that will produce a contextualized Christian funeral liturgy.

Lesson content.

1. Adventist funeral liturgy.

2. Functional Equivalency.

3. A possible funeral liturgy.

\section{objectives}

By the end of the lesson, Seminar participants should be able to:

1. Have formed their own way of dealing with funerals.

2. Suggest several functional equivalencies to some biblical funeral practices.

\section{Presentation}

\section{Introduction}

In the local villages, people follow the traditional way of burial each time someone dies. The traditional way is not exactly the same as the prescribed liturgy that Adventists follow. In the Adventist Church, ministers use the minister's manual for procedures and guidelines. These guidelines, however, are in some ways radically different from the traditional funeral rituals. Many unchurched wonder why certain things are done and why other practices found in the traditional setting are ignored. They wonder 
for example, why a cross and flowers can be laid on top of the grave and not a pot or plate. There are many adopted western cultural practices that have come into the Church of Zambia in the name of Christianity.

During this session we will try to look at the funeral liturgy that we follow as a Church world over. In this liturgy, some recommended practices are traditionally irrelevant. There are some traditional practices that are not part of the liturgy in the manual, which need to be included. All participants should think of traditional ways of burial not tainted with western influence. We will compare our findings with what the minister's manual recommends as the funeral liturgy to follow. We will then see similarities and differences. We will follow principles of functional equivalency to adapt some practices into a new contextualized liturgy.

\section{An Adventist Funeral Liturgy}

Let us begin by looking at the Adventist funeral liturgy. The Minister's Manual pages 219 ff gives us the suggested funeral liturgy. This is divided into three parts, before service, the funeral service and the graveside service.

(a) Before service. The minister is encouraged to visit the family immediately after he hears about the funeral. On reaching the bereaved family, he offers the assistance of the Church, and assistance as a pastor. If the Church is allowed to help, they can provide food, clean the house, answer the phone and direct people coming to the funeral.

The pastor finds out whether they have chosen a minister to do the service. If there are family disputes, the pastor and Church are advised to stay out of such. The pastor can only counsel if the widow is being taken advantage of.

Body viewing is done either at a funeral home or the Church. This is encouraged so that the family can face the reality of death.

(b) Funeral service. The funeral service is conducted by the funeral director who is in charge of arrangements. The minister is in charge of religious 
features of the program. The minister, before the service, meets the mourners, especially the close relatives, to assess the extent of their grief and get to know them in order to speak effectively to them.

The suggested order of service follows thus; Ministers enter, scripture is read thereafter followed by prayer. A hymn is sung which is followed by the obituary, a sermon and prayer. After a song, body viewing commences. During the funeral service it is advised that the sermon be short, Bible based, not doctrinal and must be personalized. It should include thankfulness for this life and a hope for the life to come.

(c) Graveside Service. At the grave, the funeral director signals the minister's turn for committal and where the head should point. It is suggested that a committal be brief and scriptures suggested to be read are; 1 Thess. 4:13-18 or 1 Cor. 15:51-55 or just use the formal words suggested in the manual. After committal the minister greets the family and leaves as the family departs the grave side.

\section{Functional Equivalency.}

Functional substitute is a principle of using Christian substitutes for idolatrous ceremonies. Functional substitutes help the Christian way be expressed among all people, Christian and non-Christian, in the local culture. Some patterns of Christian life are developed to let the best of Christianity be effectively demonstrated in a cultural and relevant way. In short a practice is used which will replace a non Christian practice, yet be accepted both culturally and religiously. I will give an example of memorial meetings. Memorials are done in most cultures, Tongas call this mweezyo and Bembas call it icikoloti. At this occasion beer is made, drank and offered to the deceased. As a functional substitute, there could be an annual memorial meeting at Church, here reputable characteristics of the deceased can be talked about and exhorted. The achievements of the dead are brought up to serve as good examples for those living to emulate. Beer drinking is excluded, instead some fresh juice may be served. Nothing is offered to the dead. Another functional substitute worth considering is 
the cleansing ceremony. Since cleansing is done in fear of spirits, an exorcism ceremony can be held right after burial in the evening. During this time the bereaved are dedicated to God for protection from the devil's lying schemes. As an act of cleansing, the church officers lift their hands towards the bereaved and in the name of Jesus forbid the powers of evil from using the form of the deceased, bind the powers of witchcraft, spirit mediums from taking the deceased's form and use it for any deception.

Think of other ways of possible functional substitutes your local church can use to replace the non Christian practices done at funerals.

\section{Possible Funeral Liturgy}

Now we shall break in our small groups in which we will look at the Adventist funeral liturgy, evaluate it for its effectiveness in our context. Then suggest which ways can be replaced or improved by our cultural way. Look also at our cultural practices, see what could be evil in it, try to find some functional substitutes and write out a new and contextualized funeral liturgy fit for our setting. After discussing in your groups you will bring all your suggestions and we shall together form a liturgy that may be used contextually in Zambia. We will follow this outline.

A. Before the service.

B. The service.

C. At the grave side.

D. After burial.

After groups have brought in their suggestions and their functional substitutes, a review is done and summary is made. A short prayer is offered by the pastor which closes the session.

Farewel1, Dedication prayer and end of seminar.

\section{Recommended Reading}

Mayers, Marvin K. Christianity Confronts Culture. Grand Rapids, MI: Zondervan, 1987. 
General Conference of Seventh-day Adventists. Seventh-day Adventist Church Manual. Silver Springs, MD: General Conference, 1990.

General Conference of Seventh-day Adventists. Manual for Ministers. Washington, DC: Ministerial Association, 1978 . 
BIBLIOGRAPHY 


\section{BIBLIOGRAPHY}

Amey, Dorothea. Missionary to Zambia. Interview by author, January 3, 1996.

Badham, Paul. Christian Beliefs about Life after Death. London: MacMillan, 1976.

Biare, Francis Wright. The Gospel According to Matthew. San Francisco: Harper \& Row, 1982 .

Benjamin, Don C. Deuteronomy and City Life. New York: University Press of America, 1983.

Binsbergen, Wm. M. J. Van. Religious Change in Zambia. London: Kegan Paul, 1981.

Bloch-Smith, Elizabeth. Judahite Burial Practices and Beliefs About the Dead. Sheffield, England: JSOT, 1992 .

Bolton, C., and D. J. Camp. "Funeral Rituals and the Facilitation of Grief Work." Omega 17, no. 4 (1987): $343-353$.

Booth, Newell S., Jr. "Time and Change in African Traditional Thought." Journal of Religion in Africa 7, no. 2 (1975): $81-91$.

Bosch, David J. Transforming Mission. Maryknoll, NY: Orbis, 1993.

Brelsford, W. V. The Tribes of Zambia. Lusaka, Zambia: Government Printers, 1965. 
Brotzman, Ellis Robert. "The Plurality of 'soul' in the old Testament with Special Attention Given to the Use of 'Nephesh'." Ph.D. dissertation, New York University, 1987 .

Brown, Francis, ed. The New Brown, Driver, Briggs, Gesenius Hebrew Aramaic English Lexicon. Grand Rapids: Baker, 1981.

The Message of Deuteronomy. Downers Grove, IL: InterVarsity, 1993 .

Bubeck, Mark I. The Adversary: The Christian Versus Demonic Activity. Chicago: Moody, 1978.

Butler, Carolyn. "To Turn Them from the Power of satan to God." In The Gospel Unlimited. Pasadena, CA: William Carrey, 1994.

Carmody, Brendan P. Conversion and Jesuit Schooling in Zambia. New York: Brill, 1992.

Carvey, Brian. Bembaland Church. New York: Brill, 1994.

Chimoga, Irene. Student from Zambia studying at Lake Michigan College. Interview by author, August 12, 1995.

Coillard, Francois. on the Threshold of Central Africa. London: Frank Cass, 1971.

Colson, Elizabeth. "Spirit Possession Among the Tonga of Zambia." In Spirit Mediumship and Society in Africa, ed. John Beattie and John Middleton. London: Routledge and Kegan Paul, 1969.

Cross, Patricia K. Adults as Learners. San Francisco: Jossey-Bass, 1981.

Cross, Patricia, and John Valley, eds. Planning NonTraditionalprograms. San Francisco: Jossey-Bass, 1974. 
Dale, Andrew, and Edwin Smith. The Ila-Speaking Peoples of Northern Rhodesia. New York: University Books, 1968.

Derricourt, Robin. Man on the Kafue: The Archaeology and History of Itezhitezhi Area of Zambia. New York: Barber, 1985.

- People of the Lakes: Archaeological studies in Northern Rhodesia. Manchester: Manchester University, 1980 .

Dunbar, Colin Alfred. "The Bible Instructor: A Manual for the Training of Lay Bible Instructors." D.Min. Dissertation, Andrews University, 1992.

Dwyer, John C. Church History: Twenty Centuries of Catholic Christianity. New York: Paulist, 1985.

Eagan, Paul, and Lean Eagan. Missionaries to Zambia. Interview by author, January 3, 1996.

The Eerdmans Bible Dictionary. Edited by Allen Myers. Grand Rapids: Eerdmans, 1987. S.v. "Burial."

Epstein, A. L. Urbanization and Kinship: The Domestic Domain on the Copperbelt of Zambia 1950-1956. London: Academic, 1981.

The Europa Yearbook. Vol. 2. London: Europa Pub., 1995.

Fagan, Brian M., D. W. Phillipson, and S. G. H. Daniels. Iron Age Cultures in Zambia. London: Chatto \& Windus, 1969.

Fieldman, Emmanuel. Biblical and Post-Biblical Defilement and Mourning: Law as Theology. New York: Ktav, 1977.

Fiske, Adele M. "Death: Myth and Ritual." Journal of the American Academy of Religion 37 (1969): 249-265.

Frazer, Donald. Winning a Primitive People. Westport, CT: Negro, 1970 . 
Ganley, John. "After the Priest Leaves." African Ecclesial Review 27, no. 2 (February 1982): 25-32.

Gann, L. H. The Birth of a Plural Society. Westport, CT: Greenwood, 1981 .

General Conference of Seventh-day Adventists. Seventh-day Adventist Church Manual. Silver Spring, MD: General Conference, 1990.

General Conference of Seventh-day Adventists. Manual for Ministers. Washington, DC: Ministerial Association, 1978 .

"Genesis." The Seventh-day Adventist Bible Commentary. Edited by F. D. Nichol. Washington, DC: Review and Herald, 1976. 1:315.

George, Carl F., and Robert E. Logan. Leading and Managing Your Church. Old Tappan, NJ: Fleming H. Revell, 1987.

Gibson, John C. L. Genesis. Vol. 2. Philadelphia: Westminster, 1982 .

Goldberg, Louis. Deuteronomy. Grand Rapids: Zondervan, 1986 .

Gouldsburry, Gullen, and Hubert Sheane. The Great Plateau of Northern Rhodesia. New York: Negro University, 1969 .

Green, Ronald. "Religion and Morality in the African Traditional setting." Journal of Religion in Africa 14, no. 1.(1993): 1-23.

Grunlan, Stephen A., and Marvin K. Mayers. Cultural Anthropology: A Christian Perspective. Grand Rapids: Zondervan, 1988.

Haar, Gerrie Ter. Spirit of Africa. London: Hurst, 1992.

Hare, Douglas. Interpretation: Matthew. Louisville: Knox, 1993. 
Harper's Bible Dictionary. Edited by Paul J. Achtemeier. San Francisco: Harper and Row, 1985. S.v. "Burial."

Hall, Richard. Zambia. New York: Frederick A. Praeger, 1967 .

Hesselgrave, David J., and Edward Romen. Contextualization. Grand Rapids: Baker, 1992.

Hiebert, Paul G. Anthropological Insights for Missionaries. Grand Rapids: Baker, 1985.

Hill, David. The New Century Bible Commentary. Grand Rapids: Eerdmans, 1981.

Hinfelaar, Hugo F. Bemba Speaking Women of Zambia in A Century of Religious Change (1892-1992). New York: Brill, 1994 .

Hodder, Ian. Symbols in Action: Ethno-archaeological Studies of Material Culture. London: Cambridge University, 1982 .

Irion, Paul E. "Changing Pattern of Ritual Response to Death." Omega 22, no. 3 (1991): 159-172.

Japhet, Sara. 1 \& 2 Chronicles. London: SCM, 1993.

Johnson, Walton R. Worship and Freedom. New York: Africana, 1977.

Jules-Rosette, Bennetta. "Faith Healers and Folk Healers: The Symbolism and Practice of Indigenous Therapy in Urban Africa." Religion 11 (1981): 127-149.

Kabambe, Francis. A Zambian studying at Andrews University. Interview by author, september 10, 1995.

Kaluwe, Godwin. Pastor from Zambia Studying at Andrews University. Interview by author, August 28, 1995. 
Kaoma, Peter. A Zambian Lay leader Studying at Andrews University. Interview by author, September 2, 1995.

Kapenzi, Geoffrey $Z$. "Rites of Passage in Four African Tribes." Missiology 3 (1975): 65-67.

Kaplain, Irving. Area Handbook for Zambia. Washington, DC: The American University, 1974.

, ed. Zambia: A country Study. Washington, DC:

The American University, 1979.

Kisaka, John A. "The Adventist Church's Position and Response to Socio-cultural Issues in Africa." D.Min. dissertation, Andrews University, 1979.

Knowles, Malcom. The Adult Learner: A Neglected Species. Houston: Gulf, 1984.

Knight, G. A. F. Leviticus. Philadelphia: Westminster, 1981.

Kraft, Charles H. Christianity in culture: A Study in Dynamic Biblical Theologizing in Cross-cultural perspectives. Maryknoll, NY: Orbis, 1979. 1992 .

Ladislav, Holy. Strategies and Norms in a Changing Matrilineal Society: Descent, Succession and Inheritance Among the Toka of Zambia. London: Cambridge, 1986.

La Fontaine, J. S., ed. The Interpretation of Ritual. London: Tavistock, 1972 .

Lamm, Maurice. The Jewish Way in Death and Mourning. New York: Jonathan David, 1969.

Larkin, William, Jr. Culture and Biblical Hermeneutics. Grand Rapids: Baker, 1988. 
Leupold, H. C. Exposition of Genesis. Grand Rapids: Baker, 1953 .

Lewis, I. M. Social Anthropology in Perspective: The Relevance of Social Anthropology. London: Cambridge University Press, 1985.

-Liddel1, Henry George, and Robert Scott. A Greek-English Lexicon. Oxford: Clarendon, 1973. s.v. "Psuche."

Lincoln, Bruce. "Two Notes on Modern Rituals." Journal of the American Academy of Religion 45, no. 2 (1977): 147160 .

Littlewood, Jane. Aspects of Grief: Bereavement in Adult Life. London: Tavistock, 1992.

Mainga, Mutumba. Bulozi Under the Iuyana Kings. London: Longmans, 1973 .

Marrais, Henry. "A King Reborn: The Story of the Conversion of the Litunga, King of Barotseland." Trans-Africa Division Outlook, August 1980, 3 .

Marteus, Elmer A., and Howard H. Charles, eds. Matthew: Believers' Church Bible Commentary. Scottdale, PA: Herald, 1991.

Mayers, Marvin K. Christianity Confronts Culture. Grand Rapids: Zondervan, 1987.

Mbiti, John S. African Religions and Philosophy. Oxford: Heinemann, 1990.

MCAlpine, Thomas H. Sleep, Divine \& Human, in the Old Testament. Sheffield, England: JSOT, 1987.

McCane, Byron. "Jews, Christians, and Burial in Roman Palestine." Ph.D. dissertation, Duke University, 1992 . 
Mclean, David A., and Ted J. Solomon. "Divination Among the Bena Lulua." Journal of Religion in Africa 4, no. 1 (1971): $25-44$.

Meier, John P. "Catholic Friends in the Light of Scripture." Worship 48, no. 4 (1974): 206-216.

Metcalf, Peter, and Richard Huntington. Celebrations of Death: The Anthropology of Mortuary Ritual. Cambridge: Cambridge University Press, 1991.

Miller, Haskel M. A Christian Critigue of culture. New York: Abingdon, 1965.

Minear, Paul S. Matthew: The Teacher's Gospel. New York: Pilgrim Press, 1982 .

Mmembe, Joseph. A Zambian. Interview by author, August 12, 1995 .

Morris, Geo. S. Philosophy and Christianity. New York: Robert Carter \& Bro., 1975.

Mubita, Imasiku. A Zambian Seminary student studying at Andrews University. Interview by author, August 12, 1995 .

Munyengwe, Coaster, Mrs. A Zambian. Interview by author, August 12, 1995.

Murray, Andrew. Divine Healing. Springdale, PA: Whitaker, 1982 .

Mushili, Bessie Mwenya, Mrs. A Zambian. Interview by author, July 16, 1995 .

Mwansa, Mwewa. A Zambian Student studying at Southwestern Michigan College. Interview by author, August 13, 1995 .

Mwansa, Pardon. "A Training Program in Pastoral Responsibilities for Church Elders in Lusaka, Zambia." D.Min. dissertation, Andrews University, 1993. 
Nagakubo, Senzo. "Investigation into Jewish Concept of Afterlife in the Beth she'Arim Greek Inscriptions." Ph.D. dissertation, Duke University, 1974.

Ncube, Zebron M. "Ancestral Practices: A Program Designed to Create Faith Among Adventists in Zimbabwe." D.Min. dissertation, Andrews University, 1988.

Ndatoya, B. Church Ministries Director, Zambia Union of Seventh-day Adventists. Telephone Interview by author, January $31,1996$.

Obayashi, Hiroshi, ed. Death and Afterlife: Perspectives of World Religions. New York: Greenwood, 1992.

Page, Allen. Life after Death: What the Bible Says. Nashville: Abingdon, 1987.

Parry, Jonathan. "Sacrificial Death and the Necrophagous ascetic." In Death and the Regeneration of Life. London: Cambridge University Press, 1982.

Payne, J. B. "Burial." The International standard Bible Encyclopedia. Grand Rapids: Eerdmans, 1979.

The Perennial Dictionary of World Religions. Edited by Keith Crim. San Francisco: Harper \& Row, 1989. S.v. "Soul, Spirit."

Phypers, David. Christian Marriage in Crisis. Whitstable, England: Marc Europe, 1985.

Raelly, Lassew Dennis. "The Development of a Theologically Undergirded strategy for Mission Employing Small Group Structure in the S.D.A. Church in Zambia." D.Min. dissertation, Andrews University, 1981.

Randal, Max Ward. Profile for Victory: New Proposals for Missions in Zambia. Pasadena, CA: Carrey, 1970.

Rando, Therese A. Grief, Dying and Death: Clinical Intervention for Care Givers. Champaign, IL: Research, 1984 . 
Reynolds, Barrie. Magic. Divination and Witchcraft Among the Barotse of Northern Rhodesia. Los Angeles: University of California, 1963.

Reynolds, Pamela. Dance Civet Cat: Child Labor in the Zambezi Valley. London: Zed, 1991.

Rheenen, Gailyn Van. Communicating Christ in Animistic Contexts. Grand Rapids: Baker, 1991.

Richards, Audrey I. Hunger and Work in a Savage Tribe. Westport, CT: Greenwood, 1985.

Riemer, Jack, ed. Jewish Reflections on Death. New York: Schocken, 1974 .

Ro, Bong Rin, ed. Christian Alternatives to Ancestral Practices. Taiwan: Asia. Theological Association, 1985.

Robert, Andrew. A History of the Bemba. Madison, WI: University of Wisconsin, 1973.

Sales, Richard W. "Neighbors in Zambia." Christian Century 102 (February 1985): 207-208.

Schwarz, Hans. Beyond the Gates of Death: A Biblical Examination of Evidence for Life after Death. Minneapolis: Augsburg, 1981.

Seventh-day Adventists Believe. Hagerstown, MD: Review \& Herald, 1988 .

The Seventh-day Adventist Bible Dictionary. Edited by Siegfried H. Horn. Washington, DC: Review and Herald, 1979. S.v. "Mourning."

Shewmaker, Stan. Tonga Christianity. Pasadena, CA: Carrey, 1970 .

Shorter, A. "Ancestor Veneration Revisited." African Ecclesial Review 25, no. 4 (1983): 197-203. 
"Conflicting Attitudes to Ancestor Veneration in Africa." African Ecclesial Review 11, no. 1 (1969): $27-37$.

Smith, Robert. Augsburg Commentary on the New Testament: Matthew. Minneapolis: Augsburg, 1989.

Staples, Russell Lynn. "Christianity and the Cult of the Ancestors: Belief and Ritual Among the Bantu-speaking Peoples of Southern Africa." Ph.D. dissertation, Princeton Theological Seminary, 1982 .

Sperling, Abraham I. Reasons for Jewish Customs and Traditions. New York: Bloch, 1968.

Solomon, Poovelingan R. "Ashram: A Contextualized Model for Discipling the Hindus of Tamil Nadu." D.Min. dissertation, Andrews University, 1994.

Tabler, Edward C., ed. Trade and Travel in Early Barotseland. Los Angeles: University of California, 1963.

Tetlow, Elizabeth Meier, and Louis Mulry Tetlow. Partners in Service: Toward a Biblical Theology of Christian Marriage. New York: University of America, 1983.

Theological Dictionary of the New Testament. Edited by Gerhard Kittel and Gerhard Friedrich. Grand Rapids: Eerdmans, 1985. S.v. "Psuche:"

Thomas, Ken, and Shirley Thomas. Missionaries to Zambia. Interview by author, January 3, 1996.

Thompson, J. A. The New American Commentary: 1 \& 2 Chronicles. Vol. 9. N.p.: Broadman \& Holman, 1994.

Turner, Victor. The Forest Symbols: Aspects of Ndembu Ritual. New York: Cornell, 1967.

Uchendu, Victor C. "Ancestrocide! Are African Ancestors Dead?" In Ancestors, ed. William H. Newel. Chicago: Mouton, 1976. 
Verstraelen-Guilhuis, Gerdien. Erom Dutch Mission Church to Reformed Church in Zambia. Franeker, Netherlands: T. Wever, 1982 .

Von Rad, Gerhard. Deuteronomy. London: SCM, 1988.

Weiss, Rabbi Abner. Death and Bereavement: A Halakhic Guide. Hoboken, NJ: Ktav, 1991.

Wendland, E. H. of other Gods and other spirits.

Milwaukee: Northwestern, 1977.

Werner, Douglass. "Some Developments in Bemba Religious History." Journal of Religion in Africa 4, no. 1 (1971) : 1-24.

Westermann, Claus. Genesis 37-50: A Commentary.

Minneapolis: Augsburg, 1986.

White, Arthur L. "Charismatic Experiences in early Seventhday Adventist History." A Reprint of twelve articles published in the Review and Herald, August 10, 17, 24, 1972; March 15, 22, 29, April 5, 12, 19, 26, and August 2, 9, 1973. Ellen $G$ White Research Center.

Andrews University, Berrien Springs, Michigan.

White, Ellen G. The Acts of the Apostles. Boise, ID:

Pacific Press, 1989.

1940 .

The Desire of Ages. Boise, ID: Pacific Press,

Early Writings. Washington, DC: Review \& Herald, 1945 .

to Friends on Pitcairn Island, 1 January 1894. Letter 65a, 1894. Ellen G. White Research Center, Andrews University, Berrien Springs, MI.

1950 .

The Great controversy. Boise, ID: Pacific,

Ministry of Healing. Boise, ID: Pacific, 1942. 
to Sr. Peck, 21 November 1898. Letter 103, 1898. Ellen G. White Research Center, Andrews University, Berrien Springs, MI.

"Cheerfulness in Affliction." Review and Herald, November 1, 1881, 273-274.

- Testimonies to the Church. 9 vols. Boise, ID: Pacific, 1948 .

Willis, John T. The Living word Commentary: First and second samuel. Austin, TX: Sweet, 1982.

Wilson, William. The New Wilson's Word Studies. Grand Rapids: Kregel, 1987.

Worley, Richard, and Donna Worley. Missionaries to Zambia. Interview by author, January 3, 1996.

Wright, N. T. The New Testament and the People of God. Vol. 1. Minneapolis: Fortress, 1992.

Yoder, Lonnie. "The Funeral Meal: A Significant Funeral Ritual." Journal of Religion and Health 25 , no. 2 (Summer 1986): 149-160.

Youngberg, John, and Millie Youngberg. Marriage Commitment: Participant's Manual for Marriage Commitment Seminars. Berrien Springs, MI: Andrews University, 1990. 
VITA

Personal and Family:

Name:

Date of Birth:

Place of Birth:

Wife's Name:

First Child:

second Child:
Cornelius Mulenga Matandiko September 1, 1960

Luwingu, Zambia

Patience Matandiko

Charity Mulenga Matandiko

Victoria Tinashe Matandiko

Educational accomplishments:

Bachelor of Arts, Solusi College, Zimbabwe 1985 Master of Divinity, Andrews University, USA 1993 Doctor of Ministry, Andrews University, USA 1996

Professional accomplishments:

\begin{tabular}{|c|c|c|}
\hline 1980 & -1981 & $\begin{array}{l}\text { Literature Evangelist, Kitwe, North } \\
\text { Zambia Field }\end{array}$ \\
\hline 1982 & -1983 & $\begin{array}{l}\text { District Pastor, Chingola, North Zambia } \\
\text { Field }\end{array}$ \\
\hline 1985 & - & $\begin{array}{l}\text { District Pastor, Ndola, North Zambia } \\
\text { Field }\end{array}$ \\
\hline 1986 & -1987 & Education Director, North Zambia Field \\
\hline 1987 & -1989 & $\begin{array}{l}\text { Church Ministries Director, North } \\
\text { Zambia Field }\end{array}$ \\
\hline 1990 & -1991 & $\begin{array}{l}\text { Church Ministries Director, Zambia } \\
\text { Union Mission }\end{array}$ \\
\hline
\end{tabular}

